Ground-Water Hydrology and Water Quality of the Southern High Plains Aquifer, Cannon Air Force Base, Curry County, New Mexico, 1994-2005

Scientific Investigations Report 2006-5280 


\section{Ground-Water Hydrology and Water Quality of the Southern High Plains Aquifer, Cannon Air Force Base, Curry County, New Mexico, 1994-2005}

By Jeff B. Langman, Sarah E. Falk, Fredrick E. Gebhardt, and Paul J. Blanchard

Prepared in cooperation with the U.S. AIR FORCE, CANNON AIR FORCE BASE

Scientific Investigations Report 2006-5280

U.S. Department of the Interior

U.S. Geological Survey 


\section{U.S. Department of the Interior DIRK KEMPTHORNE, Secretary}

\section{U.S. Geological Survey Mark D. Myers, Director}

\section{U.S. Geological Survey, Reston, Virginia: 2006}

For product and ordering information:

World Wide Web: http://www.usgs.gov/pubprod

Telephone: 1-888-ASK-USGS

For more information on the USGS--the Federal source for science about the Earth, its natural and living resources, natural hazards, and the environment:

World Wide Web: http://www.usgs.gov

Telephone: 1-888-ASK-USGS

Any use of trade, product, or firm names is for descriptive purposes only and does not imply endorsement by the U.S. Government.

Although this report is in the public domain, permission must be secured from the individual copyright owners to reproduce any copyrighted materials contained within this report.

Suggested citation:

Langman, Jeff B., Falk, Sarah E., Gebhardt, Fredrick E., and Blanchard, Paul J., 2006, Ground-water hydrology and water quality of the Southern High Plains aquifer: U.S. Geological Survey Scientific Investigations Report 2006-5280, $61 \mathrm{p}$ 


\section{Contents}

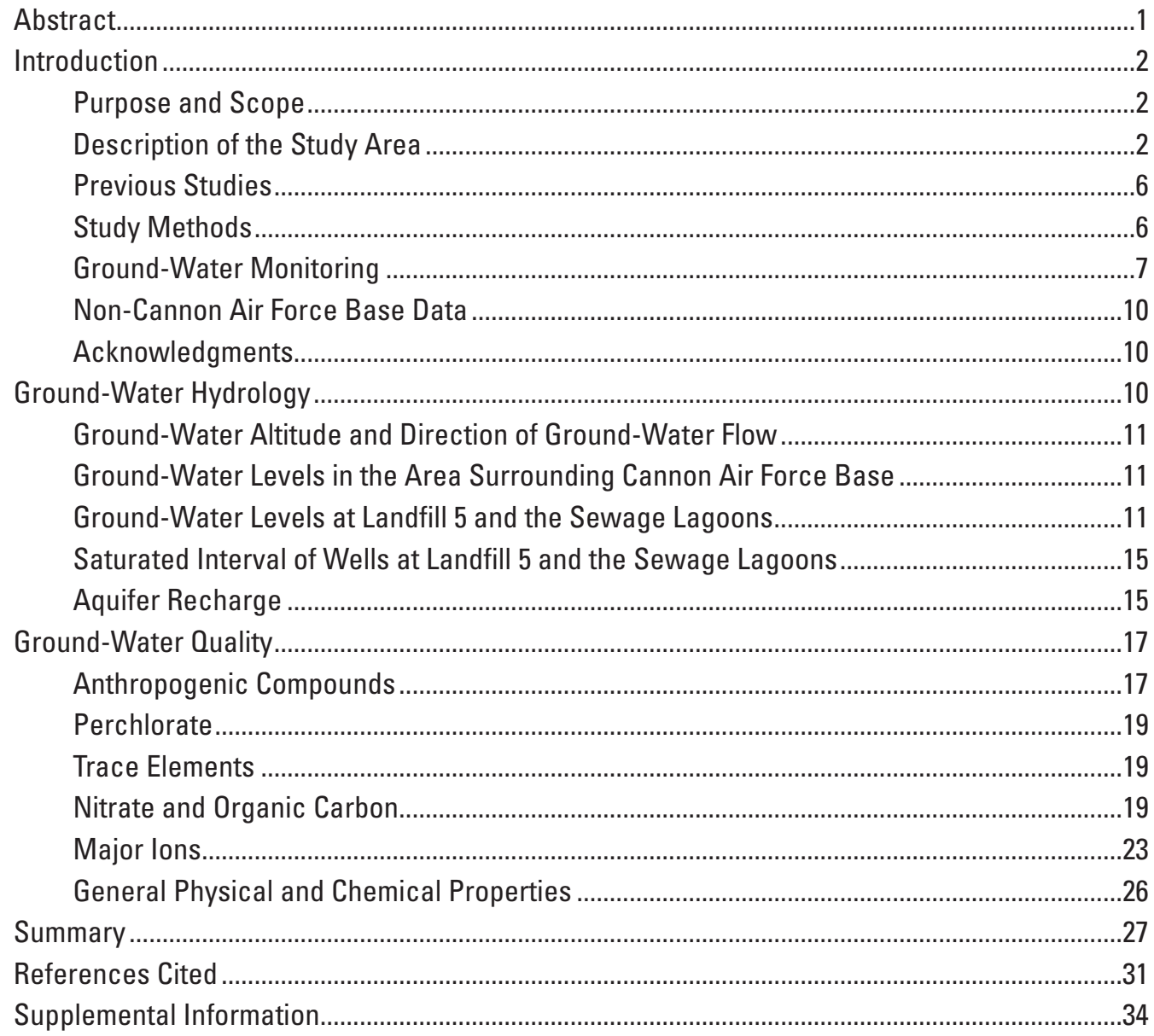

\section{Figures}

1. Map showing location of Cannon Air Force Base. ............................................................

2. Map showing location of monitoring and production wells at Cannon Air Force Base...4

3. Contours of approximate ground-water altitude and general direction of ground-water flow in the Southern High Plains aquifer in the Cannon Air Force Base area, 1962, 1967, 1977, 1987, and 1997.

4. Graph showing water level of wells with the longest periods of record in the area surrounding Cannon Air Force Base , 1954-2004

5. Graph showing water-level seasonal fluctuations in selected monitoring wells at Cannon Air Force Base, 1994-2005

6. Plot of maximum recorded trace-element concentrations in ground water at Cannon Air Force Base, 1994-2004, and U.S. Environmental Protection Agency (2005b) drinking-water standards. 
7-11. Boxplots showing:

7. Aluminum concentrations in ground water at Cannon Air Force Base, 1994-2004.

8. Iron concentrations in ground water at Cannon Air Force Base, 1994-2004 .........21

9. Manganese concentrations in ground water at Cannon Air Force Base, 1994-2004.

10. Chromium concentrations in ground water at Cannon Air Force Base, 1994-2004.

11. Total nitrate, as nitrogen, concentrations in ground water at Cannon Air Force Base, 1994-2004.

12. Graph showing total nitrate, as nitrogen, concentrations in ground water from wells near the Sewage Lagoons at Cannon Air Force Base, 1996-2004.

13. Boxplots showing total organic carbon concentrations in ground water at Cannon Air Force Base, 1994-2004.

14. Piper diagram of major-ion composition in ground water from selected wells at Cannon Air Force Base, July 2004.

15. Graph showing calcium and sulfate concentrations in ground water at Cannon Air Force Base, June 2004.

16. Graph showing cation and sulfate ratios for ground water at Cannon Air Force Base, June 2004.

17. Boxplots showing ground-water specific conductance at Cannon Air Force Base, 1994-2004.

18. Graph showing ground-water specific conductance near the Sewage Lagoons at Cannon Air Force Base, 1994-2004.

19. Graph showing ground-water specific conductance near Landfill 5 at Cannon Air Force Base, 1999-2004.

20. Boxplots showing ground-water temperatures at Cannon Air Force Base, 1994-2004

21. Boxplots showing ground-water $\mathrm{pH}$ at Cannon Air Force Base, 1994-2004 .29

I-1. Map of location of selected wells at Cannon Air Force Base and the surrounding area.

\section{Tables}

1. Cannon Air Force Base monitoring and production well information. .8

2. Periods of record for Cannon Air Force Base monitoring and production wells.

3. Water-quality constituents and laboratory analytical methods for ground-water samples collected at Cannon Air Force Base by the U.S. Geological Survey.

4. Number of wells measured during each 5-year synoptic measurement in the area surrounding Cannon Air Force Base.

5. Measurements and changes in water level for wells surrounding Cannon Air Force Base, 1954-2004.

6. Number of wells surrounding Cannon Air Force Base with decreasing or increasing water level between successive 5-year synoptic measurements, 1962-97.

7. Changes in saturated interval for selected wells surrounding Cannon Air Force Base. 
8. Measurements and changes in water level for wells near Landfill 5 and the Sewage Lagoons at Cannon Air Force Base, 1994-2005 .................................................16

9. Change in saturated interval for selected wells at Cannon Air Force Base.....................16

10. Maximum concentrations of anthropogenic compounds detected in ground-water samples collected by the U.S. Geological Survey at Cannon Air Force Base,

11. Perchlorate concentrations in ground water at Cannon Air Force Base. ......................20

I-1. Information for selected wells at Cannon Air Force Base and the surrounding area....36

I-2. Altitudes of water levels in selected wells at Cannon Air Force Base and the surrounding area.

\section{Abbreviations}

$\begin{array}{ll}\text { Cannon AFB } & \text { Cannon Air Force Base } \\ \text { MDL } & \text { method detection limit } \\ \text { min } & \text { minute } \\ \mu \mathrm{g} / \mathrm{L} & \text { micrograms per liter } \\ \mathrm{mg} / \mathrm{kg} / \mathrm{day} & \text { milligrams per kilogram per day } \\ \mathrm{mg} / \mathrm{L} & \text { milligrams per liter } \\ \mu \mathrm{S} / \mathrm{cm} & \text { microsiemens per centimeter at } 25 \text { degrees Celsius } \\ \text { NPDES } & \text { National Pollutant Discharge Elimination System } \\ \text { NWIS } & \text { National Water Information System } \\ \text { ppb } & \text { parts per billion } \\ \text { RCRA } & \text { Resource Conservation and Recovery Act } \\ \text { RL } & \text { reporting level } \\ \text { SDWA } & \text { Safe Drinking Water Act } \\ \text { SWMU } & \text { Solid Waste Management Unit } \\ \text { TOC } & \text { total organic carbon } \\ \text { USGS } & \text { U.S. Geological Survey }\end{array}$

\section{Conversion Factors and Datums}

\begin{tabular}{lll}
\hline \multicolumn{1}{c}{ Multiply } & \multicolumn{1}{c}{ By } & \multicolumn{1}{c}{ To obtain } \\
\hline inch & 2.540 & centimeter $(\mathrm{cm})$ \\
foot $(\mathrm{ft})$ & 0.3048 & meter $(\mathrm{m})$ \\
mile $(\mathrm{mi})$ & 1.609 & kilometer $(\mathrm{km})$ \\
acre & 4,047 & square meter $\left(\mathrm{m}^{2}\right)$ \\
gallon (gal) & 3.785 & liter $(\mathrm{L})$ \\
gal/min & 0.06309 & liter per second $(\mathrm{L} / \mathrm{s})$ \\
\hline
\end{tabular}

Temperature in degrees Celsius $\left({ }^{\circ} \mathrm{C}\right)$ can be converted to degrees Fahrenheit $\left({ }^{\circ} \mathrm{F}\right)$ as follows:

${ }^{\circ} \mathrm{F}=\left(1.8 \mathrm{x}{ }^{\circ} \mathrm{C}\right)+32$

Vertical coordinate information is referenced to the North American Vertical Datum of 1988 (NAVD 88).

Horizontal coordinate information is referenced to the North American Datum of 1983 (NAD 83). 


\title{
Ground-Water Hydrology and Water Quality of the Southern High Plains Aquifer, Cannon Air Force Base, Curry County, New Mexico, 1994-2005
}

\author{
By Jeff B. Langman, Sarah E. Falk, Fredrick E. Gebhardt, and Paul J. Blanchard
}

\section{Abstract}

In cooperation with the U.S. Air Force, the U.S. Geological Survey has collected hydrologic data about the Southern High Plains aquifer at Cannon Air Force Base in east-central New Mexico since 1994. Under the guidance of the State of New Mexico, ground-water quality of the aquifer has been analyzed as part of annual monitoring at regulated sites at the base. This report provides a summary and interpretation of all available hydrologic data collected by the U.S. Geological Survey for Cannon Air Force Base environmental managers for the regulated sites of Landfill 5 and the Sewage Lagoons between 1994 and 2005.

Cannon Air Force Base is in the Southern High Plains physiographic region, and saturated deposits of the Ogallala Formation underlying the base are within the western boundary of the Southern High Plains aquifer. The general direction of ground-water flow in the Southern High Plains aquifer at Cannon Air Force Base is from northwest to southeast. In 1962 , ground water predominantly flowed northwest to southeast with minimal change in direction. Ground-water altitudes declined from 1962 to 1997, and a pronounced water-level recession (area of receding water level) developed northwest of the base, altering flow direction in this area. The recession northwest of the base and the subsequent change in direction of ground-water flow are indicative of local ground-water withdrawals upgradient from Cannon Air Force Base.

Historical water levels in wells within a 3-mile radius of Cannon Air Force Base declined in 52 of 56 wells for various periods of record between 1962 and 2004. Forty-three of the wells indicated strong linear decreases with time, and the largest decline was 91.80 feet, an average annual decline of about 2.13 feet per year. Water levels in monitoring wells at Cannon Air Force Base reflected the regional decline; water levels declined for all wells with periods of record greater than 1 year, and the decreases were strongly linear. From 1994 to 2005, rates of declining water levels at the base ranged from 1.45 to 1.64 feet per year near the Sewage Lagoons and from 2.24 to 4.01 feet per year near Landfill 5. The largest variation in water levels at Cannon Air Force Base was observed in wells C, D, and S, which are located adjacent to Landfill 5 near the southern boundary of the base and near an irrigation well immediately south of the base boundary. Water levels in these wells indicated a pattern of summer water-level decline followed by partial winter water-level recovery, which was likely a result of drawdown and recovery during the irrigation and nonirrigation seasons.

Ground-water sampling by the U.S. Geological Survey from 1994 to 2004 at monitoring wells associated with Landfill 5 and the Sewage Lagoons indicated temporal and spatial differences in water quality. At least one anthropogenic compound was detected in each monitoring well, but all concentrations detected were small and less than U.S. Environmental Protection Agency drinking-water standards. Anthropogenic compounds detected were either pesticide or industrial compounds. Perchlorate was detected in at least one sample from every well for which perchlorate was analyzed, and the source of perchlorate is likely natural and a result of atmospheric deposition. Trace-element concentrations in raw (pretreatment) ground water at Cannon Air Force Base were generally less than drinking-water standards (applicable to posttreatment samples), but maximum concentrations of aluminum, iron, and manganese exceeded secondary drinking-water standards, and maximum chromium concentrations exceeded the primary drinking-water standard.

Spatial and temporal differences of nitrate, major ions, and specific conductance indicated anthropogenic and natural influences on the Southern High Plains aquifer at Cannon Air Force Base. Larger nitrate concentrations decreased in ground water near the Sewage Lagoons during and following decommissioning of the lagoons, and concentrations decreased to levels detected in ground water in wells not affected by the infiltrated wastewater. Similar cation/sulfate ratios were present for ground water from nearly all wells, except for samples from certain wells along the southern boundary of the base and the background well for the Sewage Lagoon monitoring. Temporal changes in specific conductance also indicated the declining influence of the Sewage Lagoons but additionally provided evidence of natural spatial differences in water quality at Cannon Air Force Base similar to major-ion results. Spatial differences in major ions and specific conductance indicated that ground water at Cannon Air Force Base is likely a mixture of multiple sources from different formations or recharge areas. 


\section{Introduction}

In 2005, Cannon Air Force Base (Cannon AFB) environmental managers implemented a study to review and summarize hydrologic data that were collected by the U.S. Geological Survey (USGS) at a landfill and two sewage lagoons located on the base. In cooperation with the USGS, hydrologic data were compiled and analyzed for spatial and temporal differences. The interpretation of data collected at these sites provides a characterization of the Southern High Plains aquifer that Cannon AFB environmental managers can use for future planning efforts to protect the aquifer and ensure continued operation of all current (2006) activities. Analysis of hydrologic data collected at Cannon AFB provides an overview of the aquifer, the possible anthropogenic influences on the system from past and current operations, and differences in water quality that may be attributed to natural influences.

Cannon AFB is in Curry County, New Mexico (fig. 1), about 5 mi west of Clovis, New Mexico, at an average altitude of 4,295 ft. The base was originally established in 1942 as a U.S. Army air base following the use of the airfield as the Clovis Municipal Airport. The U.S. Army air base was deactivated in 1947, then reactivated in 1951 as a U.S. Air Force base. In 2004, more than 4,000 active military and civilians were employed at Cannon AFB in support of the 27th Fighter Wing and its F-16 aircraft.

In 1994, the USGS, in cooperation with Cannon AFB, began monitoring ground-water levels and ground-water quality at a Resource Conservation and Recovery Act (RCRA) regulated site, Landfill 5, and a National Pollution Discharge Elimination System (NPDES) regulated site, Sewage Lagoons (fig. 2). From 1994 to 2005, the USGS collected data from an increasing network of monitoring wells at these two sites (fig. 2). The monitoring data were provided annually to Cannon AFB for submittal of ground-water-level and groundwater-quality data to the State of New Mexico to meet RCRA and NPDES regulatory requirements. Ground-water monitoring at these sites entailed ground-water sample collection from the unconfined aquifer at Cannon AFB, which is part of the western extension of the Southern High Plains aquifer in the Ogallala Formation.

Landfill 5 is a designated solid waste management unit (SWMU-113) at Cannon AFB and is monitored under RCRA regulations. The landfill was operated from 1968 to 1988 and was used to dispose of domestic solid waste, waste oils and solvents, paint strippers and thinners, pesticide containers, and empty cans and drums (Cannon Air Force Base, 2002). The Sewage Lagoons (SWMU-101) were constructed in 1966; discharge of treated wastewater from the Cannon AFB wastewater-treatment plant to the lagoons ceased in 1998. The lagoons consisted of two unlined surface impoundments that operated in series and received a combination of treated sanitary and industrial wastewater from base facilities (Tetra Tech EC, Inc., 2005). Following closure of the Sewage Lagoons in 1998, the area was allowed to remain undisturbed until
2003 when the remaining sludge was removed from the north lagoon and consolidated with material in the south lagoon. A protective cover and a biotic barrier were constructed as corrective actions for closing of the lagoons (Tetra Tech EC, Inc., 2005). Treated wastewater from the updated base treatment plant was diverted to Playa Lake (fig. 2) during closure of the Sewage Lagoons. With closure of the lagoons, monitoring wells in the Sewage Lagoons area are also used for monitoring of Playa Lake.

\section{Purpose and Scope}

This report describes the ground-water hydrology and water quality of the Southern High Plains aquifer at Cannon AFB. Description of the aquifer is based on available results of USGS ground-water monitoring from 1994 to 2005 of Cannon AFB monitoring wells at Landfill 5 and the Sewage Lagoons and associated background wells. Additionally, ground-wateraltitude data are presented for a 3-mi radius around the base to examine the hydrologic properties of the aquifer at Cannon AFB in relation to the regional aquifer properties. All data are presented in the context of the Southern High Plains aquifer at Cannon AFB and the surrounding area. To assist future planning efforts for use and protection of the aquifer, this report provides Cannon AFB environmental managers a summary of hydrologic data collected at Landfill 5 and the Sewage Lagoons, an overview of the Southern High Plains aquifer at Cannon AFB, the possible anthropogenic influences on the aquifer from past and current operations, and differences in water quality that may be attributed to natural influences.

\section{Description of the Study Area}

Cannon AFB is in the Southern High Plains physiographic region (Fenneman and Johnson, 1946) and lies atop a large plateau known as the Llano Estacado, which slopes gently to the east-southeast from eastern New Mexico into west Texas (Fahlquist, 2003). Topography at Cannon AFB is open and mostly flat and slopes gently to the southeast. No natural surface-water bodies are located on the base except minor ephemeral channels. Manmade ponds are located at the golf course (fig. 2) and the wastewater-treatment plant (Playa Lake). Cannon AFB is in the Plains-Mesa Grassland vegetation unit (Dick-Peddie, 1993), and natural vegetation typically consists of grasses and shrubs.

Cannon AFB is located within a semiarid region (Tuan and others, 1969). A weather station in nearby Clovis receives an average of about 17 inches of precipitation a year; average minimum and maximum temperatures are 43 and 72 degrees Fahrenheit (Western Regional Climate Center, 2005a). Most precipitation falls during the summer months, and much of the annual precipitation likely is lost to evapotranspiration. Annual pan evaporation at the weather station in Clovis averages 86.64 inches; evaporation is largest from May through August (Western Regional Climate Center, 2005b). 

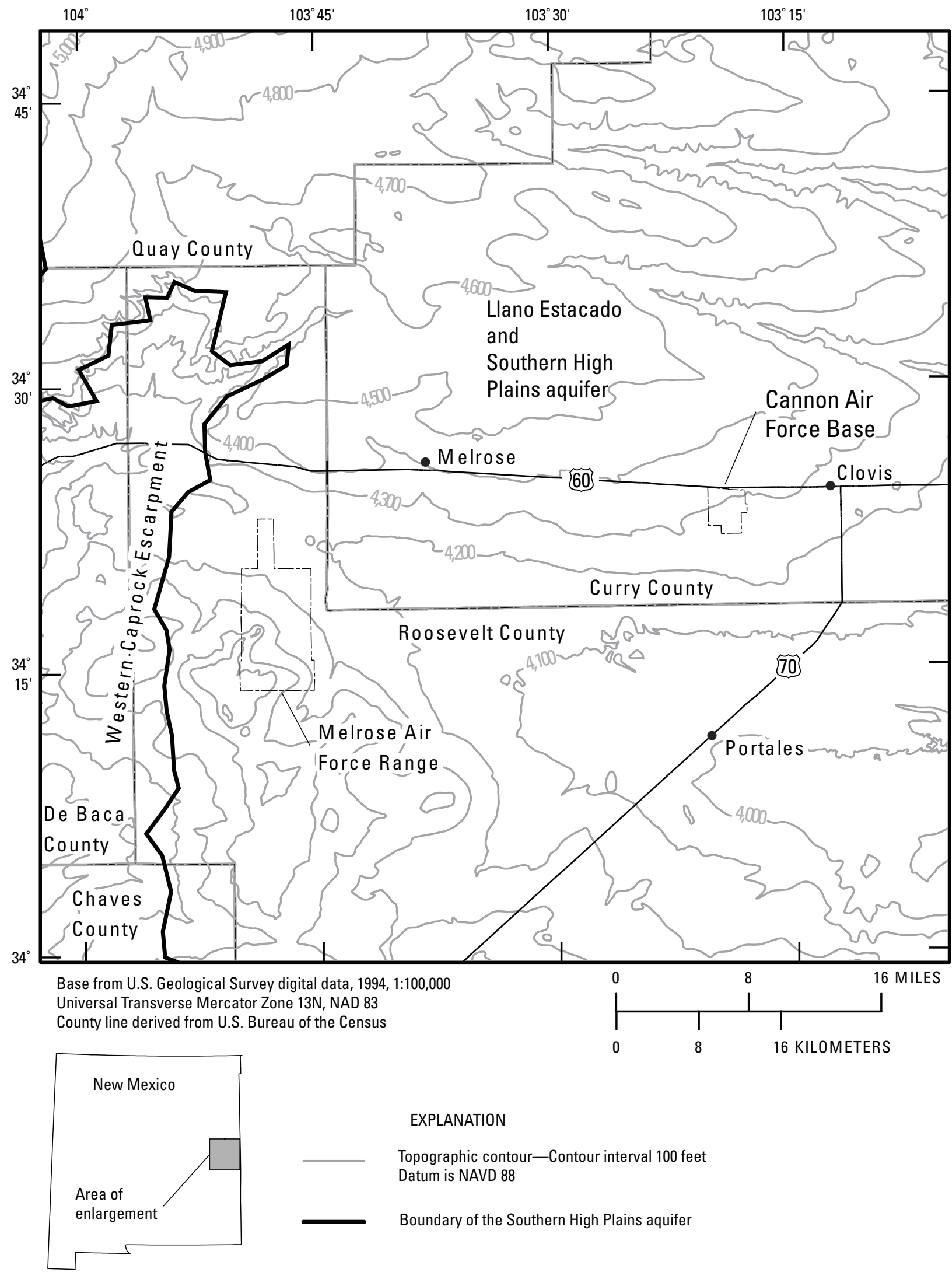

EXPLANATION

Topographic contour-Contour interval 100 feet Datum is NAVD 88

Boundary of the Southern High Plains aquifer

Figure 1. Location of Cannon Air Force Base. 


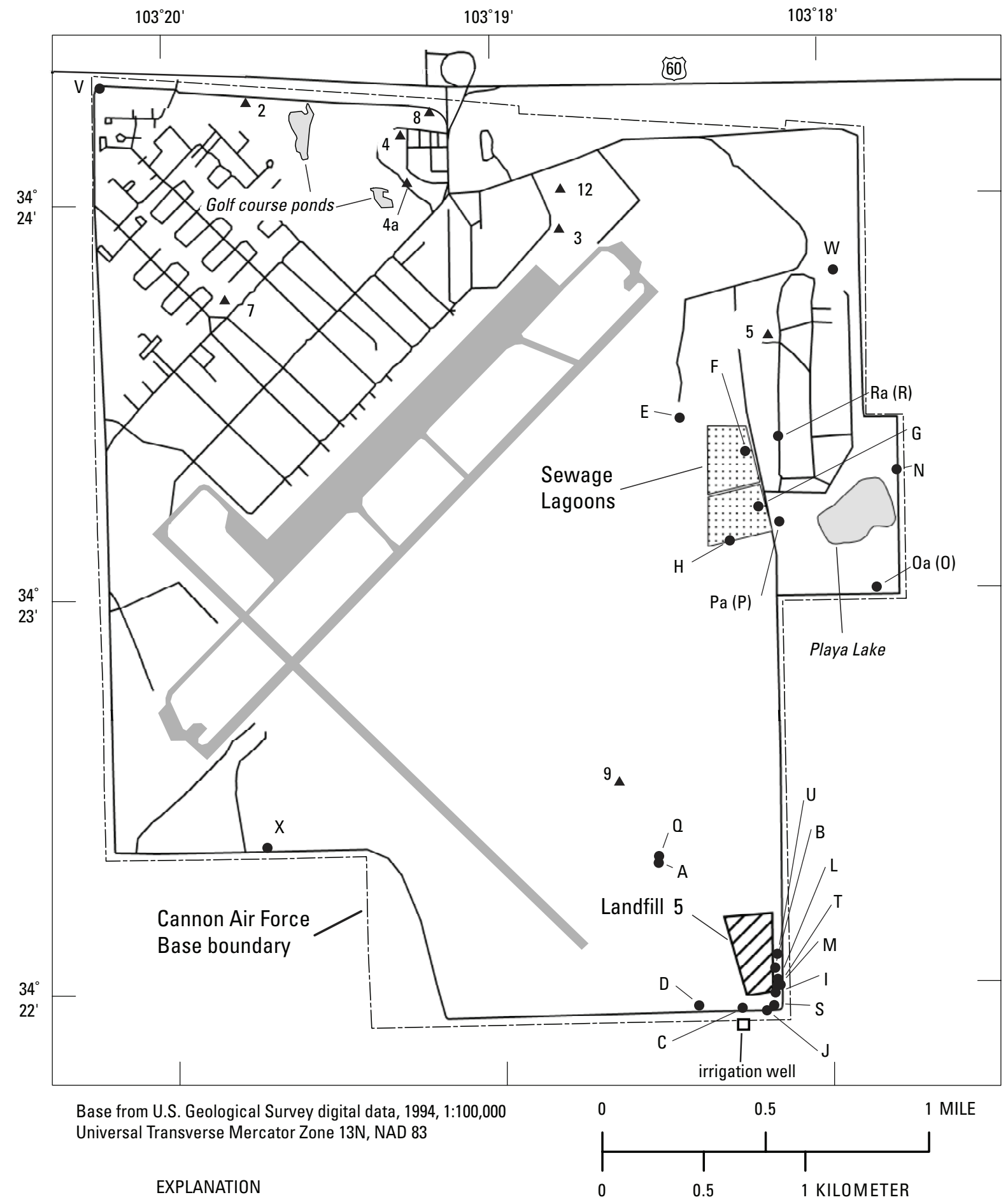

C - Monitoring well and well identifier-Identifier in parentheses indicates older well that has been replaced by well indentified with appended "a"

9 A Production well and well identifier

Figure 2. Location of monitoring and production wells at Cannon Air Force Base. 
The base is located in the Curry County ground-water basin as designated by the State of New Mexico for the Southern High Plains aquifer in New Mexico (New Mexico Office of the State Engineer, 2005). Water used at Cannon AFB is supplied by nine production wells on the base (fig. 2). From 1998 to 2003, annual pumpage from the production wells ranged from 416,787,600 (1999) to 502,524,600 (2000) gal. A total of 433,232,100 gal was pumped in 2003 (Earth Tech, Inc., 2005). Wells 2, 3, 5, 7, 8, and 12 supply potable water, and well 4 currently (2006) is offline. Well 4a supplies water to the golf course ponds, and well 9 is used solely for fire suppression supply (MWH, 2004).

The subsurface geology of the Southern High Plains aquifer at Cannon AFB includes the Chinle, Ogallala, and Blackwater Draw Formations. The Chinle Formation of Triassic age forms the bottom of the unconfined Southern High Plains aquifer in this area, consists mostly of clay with some intermixed sand and silt, and ranges in thickness from 0 to $400 \mathrm{ft}$ in eastern New Mexico (McGowen and others, 1977). The Ogallala Formation of Tertiary age is the main water-yielding unit of the Southern High Plains aquifer and lies unconformably atop the upper unit of the eastward-dipping Chinle Formation (Dutton and others, 2001). The Ogallala Formation consists of eolian sand and silt and fluvial and lacustrine sand, silt, clay, and gravel (McLemore, 2001) and ranges in thickness from 30 to $600 \mathrm{ft}$ in eastern New Mexico and west Texas (Gustavson, 1996).

The Blackwater Draw Formation of Quaternary age generally overlies the Ogallala Formation at Cannon AFB. The Blackwater Draw Formation is composed mostly of eolian sand deposits and ranges in thickness from 0 to $80 \mathrm{ft}$ in eastern New Mexico (McLemore, 2001). A caliche layer is typically present in the unsaturated zone of the Blackwater or Ogallala Formations in New Mexico (Hart and McAda, 1985). Gustavson (1996) indicated that the caliche forming the Western Caprock Escarpment west of the base (fig. 1) is pedogenic carbonate that accumulated locally during the Tertiary and Quaternary Periods and that other buried caliche layers in the Ogallala Formation are not well known. Drilling at Cannon AFB has indicated that caliche is discontinuous, typically found within $30 \mathrm{ft}$ of the surface, and of variable thickness (Fredrick Gebhardt, U.S. Geological Survey, oral commun., 2004).

The saturated Ogallala Formation deposits at Cannon AFB are within the western boundary of the Southern High Plains aquifer (Hart and McAda, 1985). In New Mexico, the Southern High Plains aquifer is part of the larger High Plains aquifer system that extends from South Dakota to Texas and is commonly referred to as the Ogallala aquifer. The part of the Southern High Plains aquifer in New Mexico is composed

\footnotetext{
${ }^{1}$ The Chinle Formation has various accepted names: Chinle Formation, Chinle Formation of the Dockum Group, and Chinle Group (U.S. Geological Survey, 2002). All three names have been used for the geologic description of areas in east-central New Mexico with usage dependent on locally identified units. "Chinle Formation" is used in this report. Locally, this formation is known as the "red beds."
}

of hydraulically connected geologic units of late Tertiary or Quaternary age and is underlain by rocks of Triassic, Jurassic, and Cretaceous age (Hart and McAda, 1985). The unconfined Southern High Plains aquifer in New Mexico is composed primarily of the Ogallala Formation (McLemore, 2001).

The Chinle Formation has informally been divided into upper and lower units (Dutton and Simpkins, 1986; McGowen and others, 1977). The upper unit is mud-rich with discontinuous sand deposits (Dutton and Simpkins, 1986) and contains a confined aquifer that typically produces only $1-2 \mathrm{gal} / \mathrm{min}$ of water (Trauger, 1972). The erosional surface of the upper unit of the Chinle creates an uneven contact with the Ogallala. Tertiary deposits filled the valleys, fluvial channels, and uplands of eroded Triassic deposits (Gustavson, 1996). Coarser material was deposited in the paleochannels, and finer sediments were deposited in the interchannel areas (Fahlquist, 2003). Sand and clay layers are known to overlie the Chinle in eastern New Mexico and west Texas, thereby creating zones of variable permeabilities across the Ogallala/Chinle contact (Nativ and Gutierrez, 1988).

The unconformity and variable deposition of sediments at the Ogallala/Chinle contact resulted in differing horizontal lithology with highly variable spatial porosity and permeability. The variable lithology results in a discontinuous aquifer in the Ogallala near the Western Caprock Escarpment that was mapped by Hart and McAda (1985). This discontinuity was not mapped at Cannon AFB and has not been identified during well installation at the base (Fredrick Gebhardt, U.S. Geological Survey, oral commun., 2005) but likely exists west of the base.

The uneven contact of the Ogallala and Chinle Formations also resulted in variable vertical permeabilities. Nativ (1988) found more permeable and less permeable sequences near the Ogallala/Chinle contact in Roosevelt County southwest of the base and variations in water quality in the Southern High Plains aquifer along the Western Caprock Escarpment that were attributed to upward leakage of Chinle water into the Southern High Plains aquifer. Langman and others (2004) described geochemical evidence of leakage from the Chinle into the Ogallala that resulted in different water types in the Southern High Plains aquifer at Melrose Air Force Range, 20 mi west of Cannon AFB.

Recharge to the Southern High Plains aquifer has been estimated to range from 0.01 inch per year (Stone and McGurk, 1985) to 1.71 inches per year (Mantei and others, 1966-1967); most estimates are less than 1 inch per year (Musharrafieh and Logan, 1999). How the aquifer is recharged has been debated, but the current conceptual model indicates that most recharge occurs through playa areas and that interplaya areas contribute little recharge (Scanlon and others, 2003).

Ground water in the New Mexico part of the Southern High Plains aquifer generally is suitable for domestic, municipal, and irrigation uses. The water typically contains large concentrations of calcium, magnesium, and bicarbonate and potentially objectionable concentrations of chloride and fluoride for domestic use (Hart and McAda, 1985). Water from 
older formations, such as the Chinle, is known to be of lesser quality (Nativ, 1988; Langman and others, 2004).

Farmers began using the Southern High Plains aquifer in the 1940s for irrigation, and about 94 percent of the water pumped from the entire High Plains aquifer in 1995 was used for irrigation (McGuire and others, 2003). Large-scale agriculture did not develop near the study area until the 1950s, but ground-water pumping has occurred since the early 1900s (Musharrafieh and Logan, 1999). In New Mexico, water-level declines in the Southern High Plains aquifer have been smaller than in other States (greater than $150 \mathrm{ft}$ in parts of west Texas), but in New Mexico the saturated thickness of the Southern High Plains aquifer is generally less than $100 \mathrm{ft}$ (year 2000) (McGuire and others, 2003).

Within New Mexico, ground water in the Southern High Plains aquifer generally flows eastward or southeastward (Hart and McAda, 1985), which is considered the overall direction of regional flow in the unconfined aquifer surrounding Cannon AFB. Fifty years of ground-water pumping has created numerous cones of depression that have reversed ground-water flow gradients around heavily irrigated areas (Musharrafieh and Logan, 1999).

\section{Previous Studies}

No hydrologic studies have been published for distribution to the public concerning the ground-water resources of Cannon AFB. The USGS and private contractors have submitted data reports to Cannon AFB for submission to the State of New Mexico for compliance with RCRA, NPDES, and Safe Drinking Water Act (SDWA) requirements.

\section{Study Methods}

This study was based on data available from USGS monitoring at Cannon AFB that included data from 12 monitoring wells at Landfill 5, 11 monitoring wells at Sewage Lagoons and Playa Lake, and 3 perimeter background wells located along the base boundary and upgradient of these two sites. Additional data include water-level measurements from wells located within an approximate 3-mi radius surrounding the base collected as part of the USGS/State of New Mexico ground-water monitoring program (data published in annual USGS Water Resource Data Reports for New Mexico) and ground-water-quality data provided by Cannon AFB environmental managers for wells $\mathrm{N}$, $\mathrm{O}, \mathrm{Oa}, \mathrm{P}, \mathrm{Pa}, \mathrm{R}$, and $\mathrm{Ra}$ and the nine production wells sampled by private contractors. Wells used for this investigation are listed in table 1 , and periods of record for data collection are listed in table 2. USGS data for wells O, P, and R and their replacements $\mathrm{Oa}, \mathrm{Pa}$, and $\mathrm{Ra}$ were combined for data analysis. Wells that went dry because of declining water levels and shallow well depths were replaced by deeper wells in the same location with the same well designation but appended with an "a". Water-quality data collected by private contractors for wells $\mathrm{N}, \mathrm{O}, \mathrm{Oa}, \mathrm{P}, \mathrm{Pa}, \mathrm{R}$, and
Ra were submitted to the State of New Mexico for annual/semiannual monitoring of RCRA-designated sites, and water-quality data for the nine production wells were submitted to the State of New Mexico per SDWA requirements. Data from private contractors were not compiled with USGS data because of differences in sampling and analytical methods. Water-quality data collected by contractors are noted when presented in the text to supplement USGS data when the contractor data may provide insight concerning water-quality differences or conditions.

To examine the decreasing water levels near and at Cannon AFB, changes to water levels were calculated for each well located within an approximate 3-mi radius surrounding the base for which there were three or more water-level measurements in the USGS National Water Information System (NWIS) database (http://nwis.waterdata.usgs.gov/). Data were analyzed for a period-of-record change in water level for wells in the Cannon AFB surrounding area and an annual and period-of-record change for wells at Cannon AFB. Additionally, linear least-squares regression was used to examine the correlation of water-level change and time $\left(\mathrm{R}^{2}\right.$ value for strength of relation).

A linear regression's $\mathrm{R}^{2}$ value indicates how well a trend line fits the water-level data and provides an indicator of model fit or the strength of the relation of the two variables (water level and time). The $\mathrm{R}^{2}$ values ranged from very small (for example, less than 0.01 ), which indicates a very poor (nearly random) fit of the trend line to the water-level data, to 0.99 , which indicates a very strong correlation of the predicted values (trend line) to the water-level data. An $\mathrm{R}^{2}$ value cannot solely indicate the predictive value of the regression model but only indicates the strength of the model in explaining the variance of the data. Its value to this analysis is the association of the indicated trend in water level over the period of record as opposed to annual fluctuations possibly associated with local pumping effects or changes to local recharge. A strong relation $\left(\mathrm{R}^{2}\right.$ greater than 0.75 was used for this study) between water level and time for a group of spatially diverse wells is indicative of regional changes (decreases or increases in water level) in the aquifer's water table.

The saturated interval of a well is discussed instead of saturated thickness of the Southern High Plains aquifer because the authors cannot confirm that all wells are screened at the bottom of the aquifer. Wells drilled by the USGS at Cannon AFB (L, M, Oa, P, Pa, S, T, U, V, W, and X) penetrate the entire thickness of the Ogallala Formation, and large screen lengths typically were installed because of declining water levels. The remaining monitoring wells at Cannon AFB (wells A-J, N, O, Q, R, Ra, and all production wells) were drilled by contractors hired by the U.S. Army Corps of Engineers. Monitoring wells installed by private contractors were typically specified to reach a set depth and screened across the water table. A review of well logs maintained by the New Mexico Office of the State Engineer for wells in the surrounding area indicated that wells in this area typically penetrate the entire Ogallala Formation, but screen placement was not recorded. 
Ground-water-quality sampling by the USGS at Cannon AFB has been motivated by RCRA and NPDES regulatory requirements for the monitoring of Landfill 5 and the Sewage Lagoons. Each site had individual requirements for the constituents to be analyzed, and wells were added to the monitoring network between 1994 and 2005. Where data were available, spatial and temporal differences in water levels and water quality were evaluated. Water-quality data from the 2005 sampling were not included because results had not been received at the time of data analysis. Water-quality data also were compared with SDWA standards established by the U.S. Environmental Protection Agency (USEPA).

SDWA standards provide a useful benchmark for evaluating the quality of ground water for potential water supply. All wells at Landfill 5 and the Sewage Lagoons are for monitoring only, and the production wells at Cannon AFB are used for water supply. SDWA standards are promulgated as posttreatment concentrations, but data collected by the USGS at Cannon AFB were derived from raw (pretreatment and unfiltered) samples for analysis of total concentrations. Comparisons between pre- and posttreatment concentrations can be misleading if the total concentration from the raw sample includes a concentration fraction resulting from suspended material that would not be present if the sample were treated for suspended sediments (such as settling or filtering).

Water-quality constituent concentrations in ground water at Cannon AFB were compared with USEPA primary and secondary drinking-water standards derived for the SDWA. Primary drinking-water standards have maximum contaminant levels (MCLs), are legally enforceable standards for public water systems, and are used to protect public health (U.S. Environmental Protection Agency, 2005b). Secondary drinking-water standards are nonenforceable guidelines for regulating contaminants that may cause cosmetic or esthetic effects in drinking water (U.S. Environmental Protection Agency, 2005b).

Water-quality constituent concentrations in ground water at Cannon AFB are presented with respect to reporting levels (RLs) and method detection levels (MDLs). An MDL is defined as the statistically calculated minimum concentration that can be measured with 99 percent confidence that the reported value is greater than zero; MDLs are determined from replicate analyses of small concentration standards in a typical representative matrix (Oblinger Childress and others, 1999). An MDL is used to control the reporting of false positives. An RL is typically the smallest concentration at which the measurement becomes quantitatively meaningful (quantitation limit) and is usually about three times the MDL (Severn Trent Laboratories, Inc., 2004). RLs are used to reduce reporting of false negatives. Concentrations between the MDL and RL are noted as estimated values.

\section{Ground-Water Monitoring}

The USGS measured water levels at Cannon AFB monitoring wells below a known, fixed altitude from 1994 to 2005 by using either an electric tape or steel tape. These water-level data were not published as part of the annual USGS Water Resources Data Reports for New Mexico as were the waterlevel data collected by the USGS outside of the base boundaries as part of the USGS/State of New Mexico ground-water monitoring program. Water-level data collected by the USGS at Cannon AFB are presented in the "Supplemental Information" section of this report. The USGS collected water-quality samples at Cannon AFB monitoring wells from 1994 to 2004 by using dedicated submersible pumps or a portable submersible pump. All ground-water samples were analyzed at the USGS contract laboratory-Severn Trent Laboratories Denver in Arvada, Colorado. During the study period, USGS sampling of monitoring wells was modified as individual wells were added or dropped, and wells were sampled annually or biannually, depending on regulatory requirements. No samples were collected from well $\mathbf{J}$ (table 1) because the well did not contain sufficient water following installation by a private contractor. Water-quality samples were collected and analyzed as total concentrations (unfiltered samples) (table 3).

Quality-assurance procedures were used for water-level measurements and for collection and processing of waterquality samples during the USGS monitoring at Cannon AFB from 1994 to 2005. Prior to purging, repeated measurements were made to ensure that water levels were stable. During purging, field values of specific conductance, water temperature, and $\mathrm{pH}$ were monitored in a flowthrough chamber and allowed to stabilize before sample collection. Stable field measurements were used to determine sufficient purge amounts for sampling formation water. Field measurements were deemed stable if a minimum of three or more sequential measurements during a minimum 10-minute period were within the following parameter ranges: specific conductance, +0.3 percent; temperature, $+0.2^{\circ} \mathrm{C}$; and $\mathrm{pH},+0.1$ standard unit (Wilde and Radtke, 2005).

Four types of quality-control samples were collected in the field during each sampling trip as part of the USGS monitoring at Cannon AFB: replicates, matrix spikes, field-equipment blanks, and trip blanks. Sequential replicate samples were collected at randomly selected wells - one for a Landfill 5 well and one for a Sewage Lagoons well- to evaluate laboratory precision. Matrix-spike and matrix-spike duplicate samples were collected to ascertain matrix interference. One field-equipment blank was collected to determine the adequacy of cleaning procedures of the portable submersible pump. Trip-blank samples were stored with volatile-organic-compound samples during transport to the laboratory to ensure that outside contaminants were not introduced to the samples. In addition, Severn Trent Laboratories used internal quality-assurance and quality-control practices including the analysis of laboratory-control and method-blank samples with the submitted USGS samples (Severn Trent Laboratories, Inc., 2004). 
Table 1. Cannon Air Force Base monitoring and production well information.

[USGS, U.S. Geological Survey; NAVD 88, North American Vertical Datum of 1988; NAD 83, North American Datum of 1983; ft bls, feet below land surface to bottom of well casing; ft, feet; PVC, polyvinyl chloride; NA, not available]

\begin{tabular}{|c|c|c|c|c|c|c|c|c|c|}
\hline $\begin{array}{c}\text { Well } \\
\text { identi- } \\
\text { fier (fig. } \\
\text { 2) }\end{array}$ & $\begin{array}{c}\text { Well } \\
\text { identifier } \\
\text { (fig. I-1) }\end{array}$ & $\begin{array}{l}\text { USGS identifi- } \\
\text { cation number }\end{array}$ & $\begin{array}{l}\text { Land-surface } \\
\text { altitude (ft } \\
\text { above } \\
\text { NAVD 88) }\end{array}$ & $\begin{array}{l}\text { Latitude } \\
\text { (NAD 83) }\end{array}$ & $\begin{array}{l}\text { Longitude } \\
\text { (NAD 83) }\end{array}$ & $\begin{array}{l}\text { Well } \\
\text { depth } \\
\text { (ft bls) }\end{array}$ & $\begin{array}{l}\text { Casing } \\
\text { material }\end{array}$ & $\begin{array}{c}\text { Screened } \\
\text { interval from } \\
\text { top of screen } \\
\text { (ft) }\end{array}$ & $\begin{array}{c}\text { Top of screen } \\
\text { altitude } \\
\text { (ft above } \\
\text { NAVD 88) }\end{array}$ \\
\hline \multicolumn{10}{|c|}{ Landfill 5 wells } \\
\hline A & 65 & 342218103182601 & $4,263.83$ & $34^{\circ} 22^{\prime} 18.91^{\prime \prime}$ & $103^{\circ} 18^{\prime} 31.44^{\prime \prime}$ & 343 & PVC & 15 & $3,935.83$ \\
\hline B & 61 & 342203103181001 & $4,262.10$ & $34^{\circ} 22^{\prime} 02.67^{\prime \prime}$ & $103^{\circ} 18^{\prime} 10.36^{\prime \prime}$ & 362 & PVC & 15 & $3,914.80$ \\
\hline c & 53 & 341256103180801 & $4,263.72$ & $34^{\circ} 21^{\prime} 56.68^{\prime \prime}$ & $103^{\circ} 18^{\prime} 16.50^{\prime \prime}$ & 362 & PVC & 15 & $3,916.72$ \\
\hline D & 56 & 342157103181701 & $4,261.94$ & $34^{\circ} 21^{\prime} 57.13^{\prime \prime}$ & $103^{\circ} 18^{\prime} 24.44^{\prime \prime}$ & 357 & PVC & 15 & $3,920.19$ \\
\hline I & 57 & 342158103180601 & $4,261.57$ & $34^{\circ} 21^{\prime} 58.94^{\prime \prime}$ & $103^{\circ} 18^{\prime} 10.39^{\prime \prime}$ & 291 & PVC & 20 & $3,990.57$ \\
\hline $\mathrm{J}^{1}$ & 54 & 342156103180802 & $4,261.11$ & $34^{\circ} 21^{\prime} 56^{\prime \prime}$ & $103^{\circ} 18^{\prime} 08^{\prime \prime}$ & NA & NA & NA & NA \\
\hline L & 60 & 342201103180901 & $4,261.38$ & $34^{\circ} 22^{\prime} 00.99^{\prime \prime}$ & $103^{\circ} 18^{\prime} 09.94^{\prime \prime}$ & 285 & PVC & 20 & $4,000.38$ \\
\hline M & 59 & 342200103181001 & $4,261.28$ & $34^{\circ} 21^{\prime} 59.94^{\prime \prime}$ & $103^{\circ} 18^{\prime} 10.07^{\prime \prime}$ & 287 & PVC & 20 & $3,999.00$ \\
\hline 0 & 66 & 342219103183101 & $4,263.50$ & $34^{\circ} 22^{\prime} 18.99^{\prime \prime}$ & $103^{\circ} 18^{\prime} 31.40^{\prime \prime}$ & 294 & PVC & 30 & $3,999.10$ \\
\hline s & 55 & 342157103181101 & $4,260.72$ & $34^{\circ} 21^{\prime} 57.01^{\prime \prime}$ & $103^{\circ} 18^{\prime} 10.70^{\prime \prime}$ & 365 & PVC & 40 & $3,976.72$ \\
\hline $\mathrm{T}$ & 58 & 342200103180901 & $4,260.82$ & $34^{\circ} 22^{\prime} 00.07^{\prime \prime}$ & $103^{\circ} 18^{\prime} 09.47^{\prime \prime}$ & 365 & PVC & 40 & $3,976.82$ \\
\hline U & 62 & 342205106181001 & $4,262.27$ & $34^{\circ} 22^{\prime} 04.81^{\prime \prime}$ & $103^{\circ} 18^{\prime} 09.93^{\prime \prime}$ & 365 & PVC & 40 & $3,978.27$ \\
\hline \multicolumn{10}{|c|}{ Sewage Lagoons and Playa Lake wells } \\
\hline $\mathrm{E}$ & 94 & 342328103182401 & $4,279.70$ & $34^{\circ} 23^{\prime} 26.51^{\prime \prime}$ & $103^{\circ} 18^{\prime} 26.23^{\prime \prime}$ & 373 & PVC & 15 & $3,924.70$ \\
\hline $\mathrm{F}$ & 89 & 342321103181001 & $4,274.93$ & $34^{\circ} 23^{\prime} 21.29^{\prime \prime}$ & $103^{\circ} 18^{\prime} 14.32^{\prime \prime}$ & 375 & PVC & 15 & $3,919.93$ \\
\hline G & 86 & 342313103180801 & $4,276.46$ & $34^{\circ} 23^{\prime} 12.86^{\prime \prime}$ & $103^{\circ} 18^{\prime} 12.07^{\prime \prime}$ & 372 & PVC & 15 & $3,919.46$ \\
\hline $\mathrm{H}$ & 81 & 342307103181601 & $4,275.98$ & $34^{\circ} 23^{\prime} 07.72^{\prime \prime}$ & $103^{\circ} 18^{\prime} 17.43^{\prime \prime}$ & 375 & PVC & 15 & $3,920.98$ \\
\hline $\mathrm{N}$ & 87 & 342317103174701 & $4,265.88$ & $34^{\circ} 23^{\prime} 18.11^{\prime \prime}$ & $103^{\circ} 17^{\prime} 46.60^{\prime \prime}$ & 297 & PVC & 30 & $3,998.88$ \\
\hline 0 & 78 & 342304103174401 & $4,269.26$ & $34^{\circ} 23^{\prime} 00.25^{\prime \prime}$ & $103^{\circ} 17^{\prime} 50.42^{\prime \prime}$ & 303 & PVC & 30 & 3,995.95 \\
\hline Oa & 77 & 342300103175001 & $4,270.11$ & $34^{\circ} 23^{\prime} 00.33^{\prime \prime}$ & $103^{\circ} 17^{\prime} 50.60^{\prime \prime}$ & 365 & PVC & 60 & $3,970.11$ \\
\hline $\mathrm{P}$ & 82 & 342309103180601 & $4,270.55$ & $34^{\circ} 23^{\prime} 10.43^{\prime \prime}$ & $103^{\circ} 18^{\prime} 08.02^{\prime \prime}$ & 300 & PVC & 20 & $4,000.55$ \\
\hline $\mathrm{Pa}$ & 85 & 342310103180801 & $4,270.85$ & $34^{\circ} 23^{\prime} 10.05^{\prime \prime}$ & $103^{\circ} 18^{\prime} 08.27^{\prime \prime}$ & 360 & PVC & 60 & $3,875.85$ \\
\hline $\mathrm{R}$ & NA & Non-USGS well & Decommiss & ioned after cor & nstruction beca & ause of st & teel pipe $u$ & Ised in construc & ting the well \\
\hline Ra & 91 & 342323103180801 & 4,272.31 & $34^{\circ} 23^{\prime} 23.50^{\prime \prime}$ & $103^{\circ} 18^{\prime} 08.23^{\prime \prime}$ & 311 & PVC & 30 & $3,991.75$ \\
\hline \multicolumn{10}{|c|}{ Perimeter background wells } \\
\hline V & 107 & 342418103201201 & $4,324.82$ & $34^{\circ} 24^{\prime} 18.00^{\prime \prime}$ & $103^{\circ} 20^{\prime} 12.62^{\prime \prime}$ & 370 & PVC & 60 & $4,019.82$ \\
\hline W & 98 & 342348103175801 & $4,296.95$ & $34^{\circ} 23^{\prime} 48.64^{\prime \prime}$ & $103^{\circ} 17^{\prime} 57.65^{\prime \prime}$ & 365 & PVC & 60 & $3,996.95$ \\
\hline $\mathrm{x}$ & 67 & 342222103194301 & $4,264.76$ & $34^{\circ} 22^{\prime} 22.16^{\prime \prime}$ & $103^{\circ} 19^{\prime} 43.14^{\prime \prime}$ & 336 & PVC & 40 & $3,973.76$ \\
\hline \multicolumn{10}{|c|}{ Production wells } \\
\hline 2 & NA & Non-USGS well & ${ }^{24,306}$ & $234^{\circ} 24^{\prime} 15.3^{\prime \prime}$ & ${ }^{3} 103^{\circ} 19^{\prime} 44.5^{\prime \prime}$ & 380 & Steel & 94.5 & ${ }^{24}, 021$ \\
\hline 3 & NA & Non-USGS well & 24,307 & $234^{\circ} 23^{\prime} 55.5^{\prime \prime}$ & ${ }^{3} 103^{\circ} 18^{\prime} 47.4^{\prime \prime}$ & 402 & Steel & 87 & 23,997 \\
\hline 4 & NA & Non-USGS well & ${ }^{24,313}$ & $234^{\circ} 24^{\prime} 10.0^{\prime \prime}$ & ${ }^{3} 103^{\circ} 19^{\prime} 16.2^{\prime \prime}$ & 357 & Steel & 51 & ${ }^{2} 4,010$ \\
\hline $4 a$ & NA & Non-USGS well & ${ }^{2} 4,316$ & ${ }^{2} 34^{\circ} 24^{\prime} 02.8^{\prime \prime}$ & ${ }^{3} 103^{\circ} 19^{\prime} 15.0^{\prime \prime}$ & 411 & Steel & 60 & 23,965 \\
\hline 5 & NA & Non-USGS well & ${ }^{2} 4,293$ & ${ }^{2} 34^{\circ} 23^{\prime} 38.9^{\prime \prime}$ & ${ }^{3} 103^{\circ} 18^{\prime} 09.4^{\prime \prime}$ & 402 & Steel & 102 & ${ }^{2} 4,009$ \\
\hline 7 & NA & Non-USGS well & 24,319 & $234^{\circ} 23^{\prime} 45.4^{\prime \prime}$ & ${ }^{3} 103^{\circ} 19^{\prime} 48.8^{\prime \prime}$ & 382 & Steel & 90 & ${ }^{24,039}$ \\
\hline 8 & NA & Non-USGS well & ${ }^{24}, 321$ & $234^{\circ} 24^{\prime} 13.5^{\prime \prime}$ & ${ }^{3} 103^{\circ} 19^{\prime} 11.0^{\prime \prime}$ & 415 & Steel & 100 & ${ }^{24}, 020$ \\
\hline 9 & NA & Non-USGS well & ${ }^{24,270}$ & $234^{\circ} 22^{\prime} 31.3^{\prime \prime}$ & ${ }^{3} 103^{\circ} 18^{\prime} 38.0^{\prime \prime}$ & 385 & Steel & 49 & 23,949 \\
\hline 12 & NA & Non-USGS well & 24,314 & ${ }^{2} 34^{\circ} 24^{\prime} 01.5^{\prime \prime}$ & ${ }^{3} 103^{\circ} 18^{\prime} 47.0^{\prime \prime}$ & 410 & Steel & 50 & 23,964 \\
\hline
\end{tabular}

${ }^{1}$ Well was drilled by private contractor prior to 1994 but never contained sufficient water for sampling or water-level measurement.

${ }^{2}$ Altitude reported as feet above mean sea level; no datum indicated (Earth Tech, Inc., 2005).

${ }^{3}$ Latitude and longitude of production wells were determined from map placement (Earth Tech, Inc., 2005). 
Table 2. Periods of record for Cannon Air Force Base monitoring and production wells.

[USGS, U.S. Geological Survey; NA, not available]

\begin{tabular}{|c|c|c|}
\hline $\begin{array}{l}\text { Well identifier } \\
\text { (fig. 2) }\end{array}$ & $\begin{array}{c}\text { USGS identification } \\
\text { number }\end{array}$ & $\begin{array}{c}\text { USGS water-level/water-quality } \\
\text { period of record }\end{array}$ \\
\hline \multicolumn{3}{|l|}{ Landfill 5 wells } \\
\hline $\mathrm{A}$ & 342218103182601 & 1994-96, 2005 \\
\hline B & 342203103181001 & $1994,1995,1999-2005$ \\
\hline C & 342156103180801 & $1998-2005$ \\
\hline $\mathrm{D}$ & 342157103181701 & $1999-2005$ \\
\hline I & 342158103180601 & $1994-99$ \\
\hline$J$ & 342156103180802 & No data collected \\
\hline $\mathrm{L}$ & 342201103180901 & $1994-97$ \\
\hline M & 342200103181001 & 1994-97 \\
\hline 0 & 342219103183101 & $1997-2003$ \\
\hline$S$ & 342157103181101 & $1999-2005$ \\
\hline $\mathrm{T}$ & 342200103180901 & $1999-2005$ \\
\hline U & 342205103181001 & $1999-2005$ \\
\hline \multicolumn{3}{|c|}{ Sewage Lagoons and Playa Lake wells } \\
\hline E & 342328103182401 & $1994,1996-2005$ \\
\hline $\mathrm{F}$ & 342321103181001 & 1996-2005 \\
\hline G & 342313103180801 & 1996-2005 \\
\hline $\mathrm{H}$ & 342307103181601 & $1994,1996-2005$ \\
\hline $\mathrm{N}$ & 342317103174701 & 1996 \\
\hline 0 & 342304103174401 & 1996 \\
\hline $0 \mathrm{a}$ & 342300103175001 & ${ }^{1} \mathrm{NA}$ \\
\hline$P$ & 342309103180601 & 1995,1996 \\
\hline $\mathrm{Pa}$ & 342310103180801 & ${ }^{1} \mathrm{NA}$ \\
\hline $\mathrm{R}$ & Non-USGS well & ${ }^{1} \mathrm{NA}$ \\
\hline $\mathrm{Ra}$ & 342323103180801 & ${ }^{1} \mathrm{NA}$ \\
\hline \multicolumn{3}{|c|}{ Perimeter background wells } \\
\hline V & 342418103201201 & 2005 \\
\hline W & 342348103175801 & 2005 \\
\hline $\mathrm{X}$ & 342222103194301 & 2005 \\
\hline \multicolumn{3}{|l|}{ Production wells } \\
\hline 2 & Non-USGS well & ${ }^{1} \mathrm{NA}$ \\
\hline 3 & Non-USGS well & ${ }^{1} \mathrm{NA}$ \\
\hline 4 & Non-USGS well & ${ }^{1} \mathrm{NA}$ \\
\hline $4 a$ & Non-USGS well & ${ }^{1} \mathrm{NA}$ \\
\hline 5 & Non-USGS well & ${ }^{1} \mathrm{NA}$ \\
\hline 7 & Non-USGS well & ${ }^{1} \mathrm{NA}$ \\
\hline 8 & Non-USGS well & ${ }^{1} \mathrm{NA}$ \\
\hline 9 & Non-USGS well & ${ }^{1} \mathrm{NA}$ \\
\hline 12 & Non-USGS well & ${ }^{1} \mathrm{NA}$ \\
\hline
\end{tabular}

${ }^{1}$ The full period of record for these wells is unknown. Sampling was performed by private contractors at the request of Cannon Air Force Base according to State of New Mexico requirements. Data from these wells were not grouped with USGS data for analysis. Individual sampling periods for these wells are referenced in the text where the data are used to supplement interpretation of USGS data. 
Table 3. Water-quality constituents and laboratory analytical methods for ground-water samples collected at Cannon Air Force Base by the U.S. Geological Survey.

[USEPA/EPA, U.S. Environmental Protection Agency; SW, ${ }^{1}$ USEPA Test Methods for Evaluating Solid Wastes; MCAWW, ${ }^{2}$ USEPA Methods for Chemical Analysis of Water and Wastes; ${ }^{\circ} \mathrm{C}$, degrees Celsius]

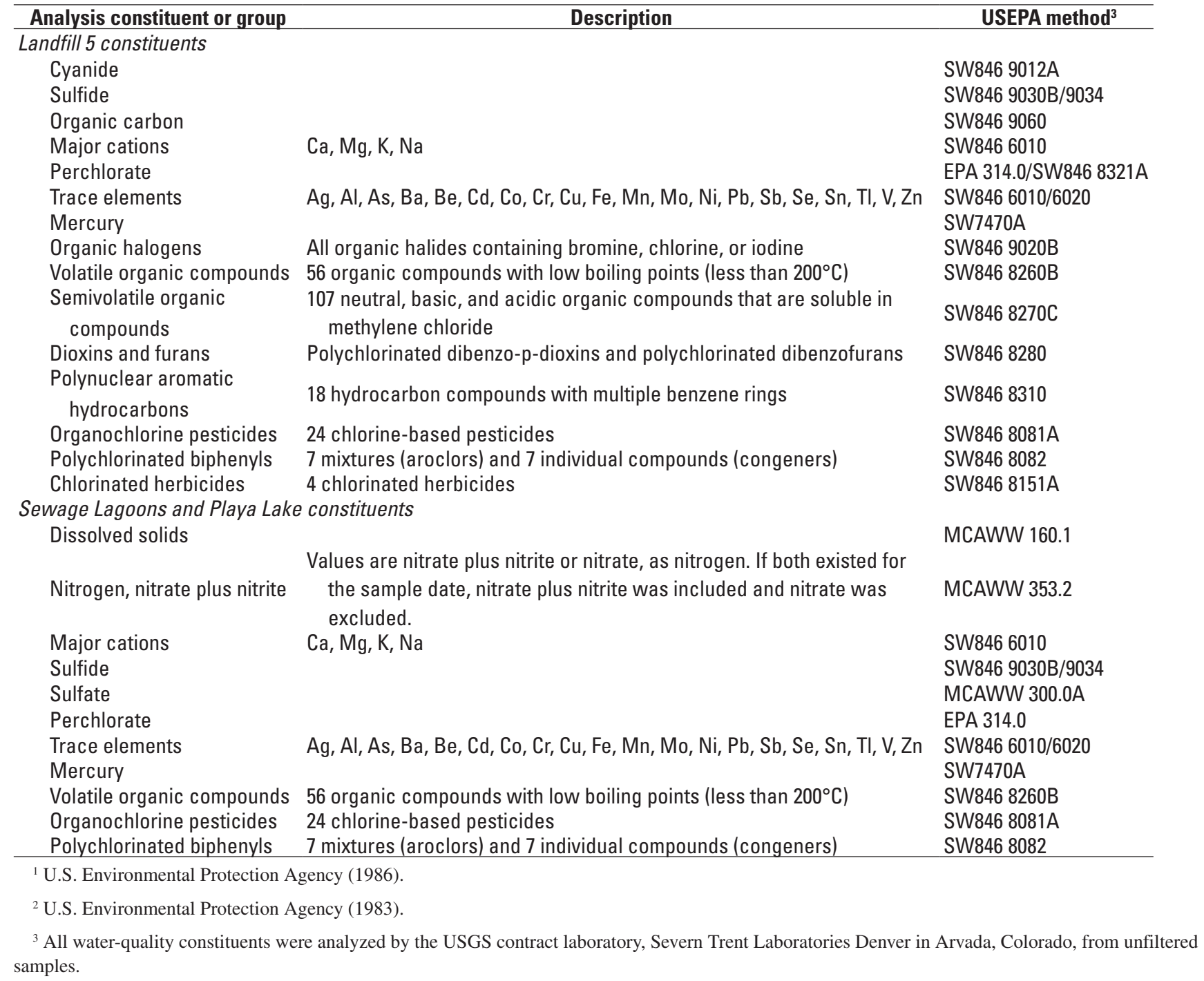

\section{Non-Cannon Air Force Base Data}

To determine ground-water flow patterns for the Southern High Plains aquifer in the vicinity of Cannon AFB, water-level measurements were retrieved from the USGS NWIS database for an approximate 3-mi radius surrounding the base. Information about these wells is listed in table I-1; well locations are shown in figure I-1, and water levels are listed in table I-2 in "Supplemental Information" (in the back of the report). Excluding the Landfill 5 and Sewage Lagoons wells, about 600 water-level measurements were available for 120 wells in the 3-mi-radius area surrounding Cannon AFB (Cannon AFB area), the earliest recorded in 1954. The majority of water-level measurements were made in January or February, typically before the onset of the irrigation season.

\section{Acknowledgments}

The authors acknowledge the support and help from the Pollution Prevention Unit of the Cannon AFB Engineering Department. Peter Zamie, Dennis Timmons, John Rebman, and Don White of Cannon AFB initiated this study and provided useful insight for completion of the study goals.

\section{Ground-Water Hydrology}

The ground-water hydrology of the Southern High Plains aquifer in the Cannon AFB area is controlled by recharge characteristics and the contact between the saturated Ogallala Formation and the underlying Chinle Formation. Substantial evapotranspiration likely limits diffuse areal recharge. 
The Ogallala/Chinle contact provides the main control for regional flow in the water-table aquifer, and pumping likely has a strong effect on local flow. Ground-water altitudes are discussed for the Cannon AFB area (regional) and Landfill 5 and Sewage Lagoons (local).

\section{Ground-Water Altitude and Direction of Ground-Water Flow}

From 1962 to 1997 , synoptic water-level measurements were conducted every 5 years in the Cannon AFB area during January through March as part of a USGS cooperative program with the State of New Mexico. The specific wells and number of wells measured varied between synoptic periods (table 4). Synoptic water-level measurements for 1962 , 1967, 1977, 1987, and 1997 were sufficient in areal coverage for determining ground-water flow patterns and comparing changes in ground-water altitude in the study area (fig. 3). The general direction of ground-water flow in the Cannon AFB area is from northwest to southeast. In 1962, the direction of ground-water flow in the Cannon AFB area was fairly uniform, and ground water predominantly flowed northwest to southeast with minimal change in direction. Ground-water altitudes declined from 1962 to 1997, and a pronounced waterlevel recession (area of receding water level) developed northwest of the base, altering flow direction in this area (fig. 3). The declining ground-water altitude in the Cannon AFB area reflects the decline in water levels in the Southern High Plains aquifer as described by McGuire and others (2003).

Table 4. Number of wells measured during each 5 -year synoptic measurement in the area surrounding Cannon Air Force Base.

\begin{tabular}{cc}
\hline $\begin{array}{c}\text { Year of synoptic water-level } \\
\text { measurement }\end{array}$ & $\begin{array}{c}\text { Number of wells } \\
\text { measured }\end{array}$ \\
\hline 1962 & 29 \\
1967 & 28 \\
1972 & 31 \\
1977 & 44 \\
1982 & 77 \\
1987 & 74 \\
1992 & 13 \\
1997 & 28 \\
\hline
\end{tabular}

\section{Ground-Water Levels in the Area Surrounding Cannon Air Force Base}

Ground-water levels have declined substantially throughout the Southern High Plains aquifer since the mid-1940s when ground water was first used for irrigated agriculture (McGuire and others, 2003). In the Cannon AFB area, three or more water-level measurements were made between 1954 and 2004 for 56 of 120 wells with data in the NWIS database (excluding the Landfill 5 and Sewage Lagoons wells). These wells included irrigation, stock, domestic, observation, and unused wells and typically were measured during winter or early spring. The largest water-level decline at a well in the Cannon AFB area was $91.80 \mathrm{ft}$ from 1962 to 2004, an average annual decline of about $2.13 \mathrm{ft}$ per year (well 40, table 5). Water levels in 52 of the 56 wells declined during the various periods of record, and water levels in 43 of the 56 wells indicated a strong linear decrease with time $\left(\mathrm{R}^{2}\right.$ greater than 0.75) (table 5).

Comparison of changes in water level between successive 5-year synoptic measurements indicates substantially more wells with decreasing than increasing water levels between each 5-year period (table 6). Wells with the longest records of water-level measurements exhibit minor periods of recovery but a dominant decline in water levels during the past 50 years (fig. 4). The declining regional water-level data likely indicate ground-water withdrawals from the aquifer that exceed recharge. The differences in slope of the declining water levels in the Cannon AFB area indicate a spatial variability (local effects) to the regional decline (fig. 4).

With declining water levels, the saturated thickness of the aquifer in the Cannon AFB area also has decreased. A smaller saturated thickness can reduce the pumping capacity of a well or enlarge the cone of depression around a pump if discharge rates are maintained. The altitude of the bottom of the Southern High Plains aquifer is variable because of the eroded surface of the Chinle Formation, which creates a variable saturated thickness in the Cannon AFB area. Wells in the Cannon AFB area with the longest records of water-level measurements indicate the effect of declining water levels on the saturated interval penetrated by the wells (table 7). The saturated interval at these wells decreased at least 35 percent for all wells, and the largest decrease was about 71 percent (well 40).

\section{Ground-Water Levels at Landfill 5 and the Sewage Lagoons}

The USGS has measured water levels in monitoring wells surrounding Landfill 5 and the Sewage Lagoons concurrently with water-sample collection since 1994. Water levels in wells at Cannon AFB reflect the regional decline that was apparent in the surrounding area; water levels declined in all wells during their periods of record except at well X (fig. 2), which had a period of record shorter than 1 year (table 8 ). The rates of decline in most wells can be separated into two spatial groups. Near the Sewage Lagoons (wells E, F, G, H, N, O/Oa, and P/Pa) (fig. 2), rates of decline ranged from 1.45 to $1.64 \mathrm{ft}$ per year; near Landfill 5 (wells B, C, D, I, L, M, S, T, and U) (fig. 2), rates of decline ranged from 2.24 to $4.01 \mathrm{ft}$ per year. The difference in rates of decline for ground water at the Sewage Lagoons and Landfill 5 was likely a result of local recharge to the aquifer near the Sewage Lagoons from infiltration of treated wastewater 

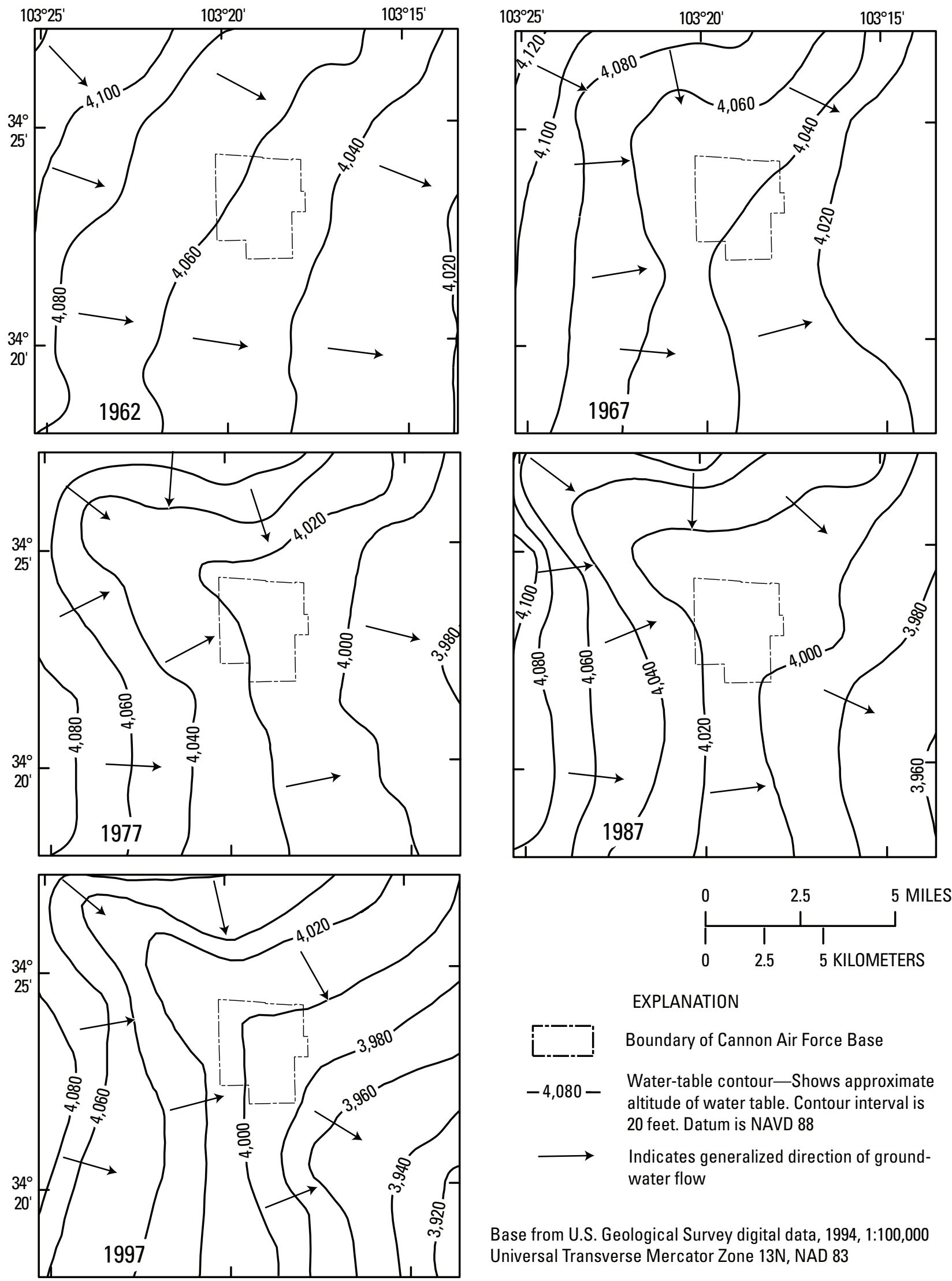

\section{EXPLANATION}

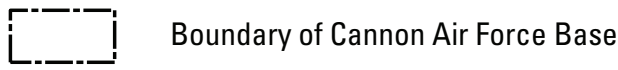

-4,080 - Water-table contour-Shows approximate altitude of water table. Contour interval is 20 feet. Datum is NAVD 88

$\longrightarrow \quad$ Indicates generalized direction of groundwater flow

Base from U.S. Geological Survey digital data, 1994, 1:100,000 Universal Transverse Mercator Zone 13N, NAD 83

Figure 3. Approximate ground-water altitude and general direction of ground-water flow in the Southern High Plains aquifer in the Cannon Air Force Base area, 1962, 1967, 1977, 1987, and 1997. 
Table 5. Measurements and changes in water level for wells surrounding Cannon Air Force Base, 1954-2004.

$\left[R^{2}\right.$, statistical value that describes the proportion of variation in the data explained by the least-squares regression model—water level relative to time]

\begin{tabular}{|c|c|c|c|c|c|c|}
\hline $\begin{array}{c}\text { Well } \\
\text { identifier } \\
\text { (fig. I-1) }\end{array}$ & $\begin{array}{l}\text { U.S. Geological Survey } \\
\text { identification number }\end{array}$ & $\begin{array}{c}\text { First } \\
\text { measurement }\end{array}$ & $\begin{array}{c}\text { Last } \\
\text { measurement }\end{array}$ & $\begin{array}{l}\text { Number of } \\
\text { measurements }\end{array}$ & $\begin{array}{l}\text { Water-level change } \\
\text { during period of record' } \\
\text { (feet) }\end{array}$ & $\mathbf{R}^{2}$ \\
\hline 1 & 341903103145601 & 01/09/80 & 01/07/87 & 5 & -18.09 & 0.98 \\
\hline 4 & 341915103180501 & $01 / 13 / 61$ & 01/28/67 & 3 & -4.42 & 0.99 \\
\hline 5 & 341918103175001 & 01/13/61 & 01/28/67 & 3 & -5.52 & 0.58 \\
\hline 6 & 341919103175001 & $01 / 18 / 77$ & 02/20/97 & 4 & -31.56 & 0.99 \\
\hline 8 & 341935103145601 & $01 / 19 / 84$ & $01 / 07 / 98$ & 14 & -46.01 & 0.93 \\
\hline 10 & 341936103155801 & $03 / 13 / 72$ & 02/19/97 & 5 & -64.57 & 0.99 \\
\hline 13 & 341944103141001 & 01/08/94 & 01/24/97 & 3 & -17.16 & 0.99 \\
\hline 20 & 342011103191701 & 01/19/77 & $01 / 23 / 97$ & 9 & -29.86 & 0.95 \\
\hline 21 & 342015103231501 & $01 / 21 / 77$ & $02 / 06 / 87$ & 3 & -5.96 & 0.99 \\
\hline 22 & 342025103211601 & $01 / 12 / 60$ & $01 / 18 / 72$ & 5 & -48.44 & 0.67 \\
\hline 23 & 342033103155801 & 02/26/69 & 03/06/04 & 29 & -81.25 & 0.98 \\
\hline 24 & 342034103170101 & $02 / 26 / 63$ & 03/12/87 & 7 & -50.77 & 0.99 \\
\hline 25 & 342034103175101 & $01 / 26 / 77$ & 03/06/04 & 5 & -65.14 & 0.99 \\
\hline 27 & 342036103201301 & $12 / 16 / 71$ & $03 / 11 / 87$ & 4 & -11.86 & 0.99 \\
\hline 28 & 342036103220001 & $01 / 10 / 67$ & 02/20/03 & 30 & -23.06 & 0.72 \\
\hline 31 & 342047103232001 & $01 / 12 / 61$ & 01/05/77 & 4 & -11.17 & 0.52 \\
\hline 36 & 342113103173401 & 07/08/75 & $01 / 15 / 87$ & 3 & -16.33 & 0.99 \\
\hline 39 & 342117103160701 & $02 / 27 / 62$ & $01 / 07 / 77$ & 3 & -32.95 & 0.88 \\
\hline 40 & 342121103142301 & 02/27/62 & 03/05/04 & 29 & -91.80 & 0.93 \\
\hline 41 & 342126103164501 & $01 / 05 / 75$ & $01 / 06 / 98$ & 23 & -45.78 & 0.96 \\
\hline 42 & 342127103185501 & 01/16/67 & 02/09/82 & 4 & -23.52 & 0.99 \\
\hline 45 & 342135103211402 & $01 / 05 / 77$ & $02 / 06 / 87$ & 4 & -10.24 & 0.97 \\
\hline 47 & 342140103190501 & 02/10/54 & 03/04/04 & 39 & -61.88 & 0.94 \\
\hline 48 & 342142103221201 & $02 / 17 / 82$ & $03 / 14 / 02$ & 5 & 0.43 & 0.00 \\
\hline 49 & 342145103232501 & 03/08/62 & $01 / 05 / 77$ & 4 & -0.81 & 0.08 \\
\hline 70 & 342232103211801 & $02 / 26 / 82$ & 02/10/87 & 3 & -4.14 & 0.99 \\
\hline 73 & 342240103175001 & 02/10/54 & 01/15/87 & 7 & -44.75 & 0.96 \\
\hline 74 & 342246103172101 & $01 / 12 / 72$ & $02 / 11 / 82$ & 3 & -12.44 & 0.99 \\
\hline 75 & 342246103204201 & 01/27/77 & 03/07/97 & 4 & 32.89 & 0.44 \\
\hline 79 & 342306103142101 & $01 / 20 / 67$ & $01 / 15 / 87$ & 5 & -23.78 & 0.96 \\
\hline 83 & 342310103160901 & 01/06/56 & 01/12/88 & 28 & -35.60 & 0.87 \\
\hline 84 & 342310103165901 & $02 / 10 / 54$ & $03 / 04 / 04$ & 7 & -59.60 & 0.98 \\
\hline 90 & 342323103145601 & 01/10/83 & 01/08/98 & 15 & -11.90 & 0.57 \\
\hline 95 & 342338103203701 & $01 / 23 / 67$ & 03/05/04 & 7 & -45.88 & 0.89 \\
\hline 97 & 342344103224901 & $02 / 17 / 82$ & 03/13/92 & 3 & 1.38 & 0.06 \\
\hline 100 & 342358103151601 & 10/27/77 & 01/15/87 & 3 & -3.85 & 0.99 \\
\hline 102 & 342404103210401 & $01 / 30 / 67$ & $02 / 05 / 87$ & 5 & -37.15 & 0.95 \\
\hline 106 & 342418103180601 & $02 / 16 / 82$ & $02 / 21 / 97$ & 3 & -10.89 & 0.97 \\
\hline 108 & 342419103232301 & $01 / 05 / 77$ & 03/07/97 & 4 & -3.99 & 0.51 \\
\hline 111 & 342442103213601 & 03/06/62 & $01 / 06 / 79$ & 12 & -48.62 & 0.95 \\
\hline 112 & 342453103141901 & $01 / 25 / 77$ & 01/15/87 & 3 & -1.28 & 0.99 \\
\hline
\end{tabular}


Table 5. Measurements and changes in water level for wells surrounding Cannon Air Force Base, 1954-2004.-Continued $\left[\mathrm{R}^{2}\right.$, statistical value that describes the proportion of variation in the data explained by the least-squares regression model—water level relative to time]

\begin{tabular}{|c|c|c|c|c|c|c|}
\hline $\begin{array}{c}\text { Well } \\
\text { identifier } \\
\text { (fig. I-1) }\end{array}$ & $\begin{array}{l}\text { U.S. Geological Survey } \\
\text { identification number }\end{array}$ & $\begin{array}{c}\text { First } \\
\text { measurement }\end{array}$ & $\begin{array}{c}\text { Last } \\
\text { measurement }\end{array}$ & $\begin{array}{c}\text { Number of } \\
\text { measurements }\end{array}$ & $\begin{array}{l}\text { Water-level change } \\
\text { during period of record }{ }^{1} \\
\text { (feet) }\end{array}$ & $\mathbf{R}^{2}$ \\
\hline 114 & 342456103195201 & $03 / 14 / 62$ & $01 / 27 / 87$ & 7 & -81.96 & 0.87 \\
\hline 115 & 342457103213901 & $01 / 31 / 72$ & $01 / 17 / 97$ & 13 & -32.25 & 0.52 \\
\hline 116 & 342505103151801 & $03 / 03 / 62$ & $01 / 06 / 98$ & 29 & -40.90 & 0.33 \\
\hline 120 & 342519103230101 & $03 / 03 / 62$ & $01 / 11 / 86$ & 20 & -53.80 & 0.85 \\
\hline 121 & 342520103165601 & $04 / 21 / 54$ & $01 / 26 / 77$ & 11 & -50.92 & 0.96 \\
\hline 123 & 342522103203801 & $03 / 03 / 62$ & $01 / 31 / 72$ & 3 & -26.81 & 0.95 \\
\hline 125 & 342532103180501 & $01 / 29 / 82$ & $02 / 21 / 97$ & 3 & -1.78 & 0.97 \\
\hline 130 & 342548103193601 & $03 / 14 / 62$ & 03/03/04 & 29 & -32.72 & 0.57 \\
\hline 134 & 342559103183401 & $02 / 23 / 82$ & $04 / 03 / 87$ & 3 & 12.80 & 0.99 \\
\hline 136 & 342609103172701 & 03/16/77 & $01 / 13 / 87$ & 3 & -5.27 & 0.95 \\
\hline 137 & 342615103220701 & $03 / 03 / 62$ & 03/07/97 & 7 & -82.73 & 0.80 \\
\hline 140 & 342630103145201 & $04 / 21 / 54$ & $02 / 04 / 77$ & 12 & -32.35 & 0.90 \\
\hline 142 & 342633103155301 & $01 / 06 / 71$ & $03 / 11 / 04$ & 24 & -20.52 & 0.76 \\
\hline 143 & 342638103162401 & $03 / 03 / 62$ & $02 / 04 / 77$ & 3 & -21.65 & 0.99 \\
\hline 144 & 342653103195201 & $01 / 20 / 69$ & $01 / 13 / 87$ & 5 & -14.12 & 0.97 \\
\hline
\end{tabular}

${ }^{1}$ Periods of record and beginning and ending dates differ among wells, which can affect comparison of water-level changes.

Table 6. Number of wells surrounding Cannon Air Force Base with increasing or decreasing water level between successive 5-year synoptic measurements, 1962-97.

\begin{tabular}{lccccccc}
\hline & $\mathbf{1 9 6 2 - 6 7}$ & $\mathbf{1 9 6 7 - 7 2}$ & $\mathbf{1 9 7 2 - 7 7}$ & $\mathbf{1 9 7 7 - 8 2}$ & $\mathbf{1 9 8 2 - 8 7}$ & $\mathbf{1 9 8 7 - 9 2}$ & $\mathbf{1 9 9 2 - 9 7}$ \\
\hline Number of wells & 20 & 19 & 24 & 33 & 65 & 13 & 11 \\
Wells with increase & 4 & 1 & 1 & 3 & 12 & 2 & 1 \\
Wells with decrease & 16 & 18 & 23 & 30 & 53 & 10 & 10 \\
\hline
\end{tabular}

Table 7. Changes in saturated interval for selected wells surrounding Cannon Air Force Base.

[Initial, initial saturated interval in feet and date of water-level measurement; Final, final saturated interval in feet and date of water-level measurement]

\begin{tabular}{|c|c|c|c|c|c|}
\hline \multirow[b]{2}{*}{ Saturated interval ${ }^{1}$} & \multicolumn{5}{|c|}{ U.S. Geological Survey identification number and map identifier ${ }^{2}$ (fig. I-1 and table I-1) } \\
\hline & $\begin{array}{c}342033103155801 \\
\text { (23) }\end{array}$ & $\begin{array}{c}342036103220001 \\
\text { (28) }\end{array}$ & $\begin{array}{c}342121103142301 \\
(40)\end{array}$ & $\begin{array}{c}342140103190501 \\
\text { (47) }\end{array}$ & $\begin{array}{c}342505103151801 \\
(116)\end{array}$ \\
\hline & 153.1 & 62.5 & 128.7 & 100.9 & 115.3 \\
\hline Inıtıal & (February 1969) & (January 1967) & (February 1962) & (February 1954) & (March 1962) \\
\hline Final & $\begin{array}{c}71.9 \\
\text { (March 2004) }\end{array}$ & $\begin{array}{c}39.5 \\
\text { (March 2004) }\end{array}$ & $\begin{array}{c}36.9 \\
(\operatorname{March} 2004)\end{array}$ & $\begin{array}{c}46.0 \\
\text { (January 1998) }\end{array}$ & $\begin{array}{c}74.4 \\
\text { (January 1998) }\end{array}$ \\
\hline $\begin{array}{l}\text { Overall decrease } \\
\text { (percent) }\end{array}$ & 53.0 & 36.8 & 71.3 & 54.4 & 35.5 \\
\hline
\end{tabular}

${ }^{1}$ Well depth and depth to water from land surface were used to calculate saturated interval.

${ }^{2}$ Well 130 (342548103193601), which is shown in figure 4, did not have a recorded well depth to determine the saturated interval at the well location. 


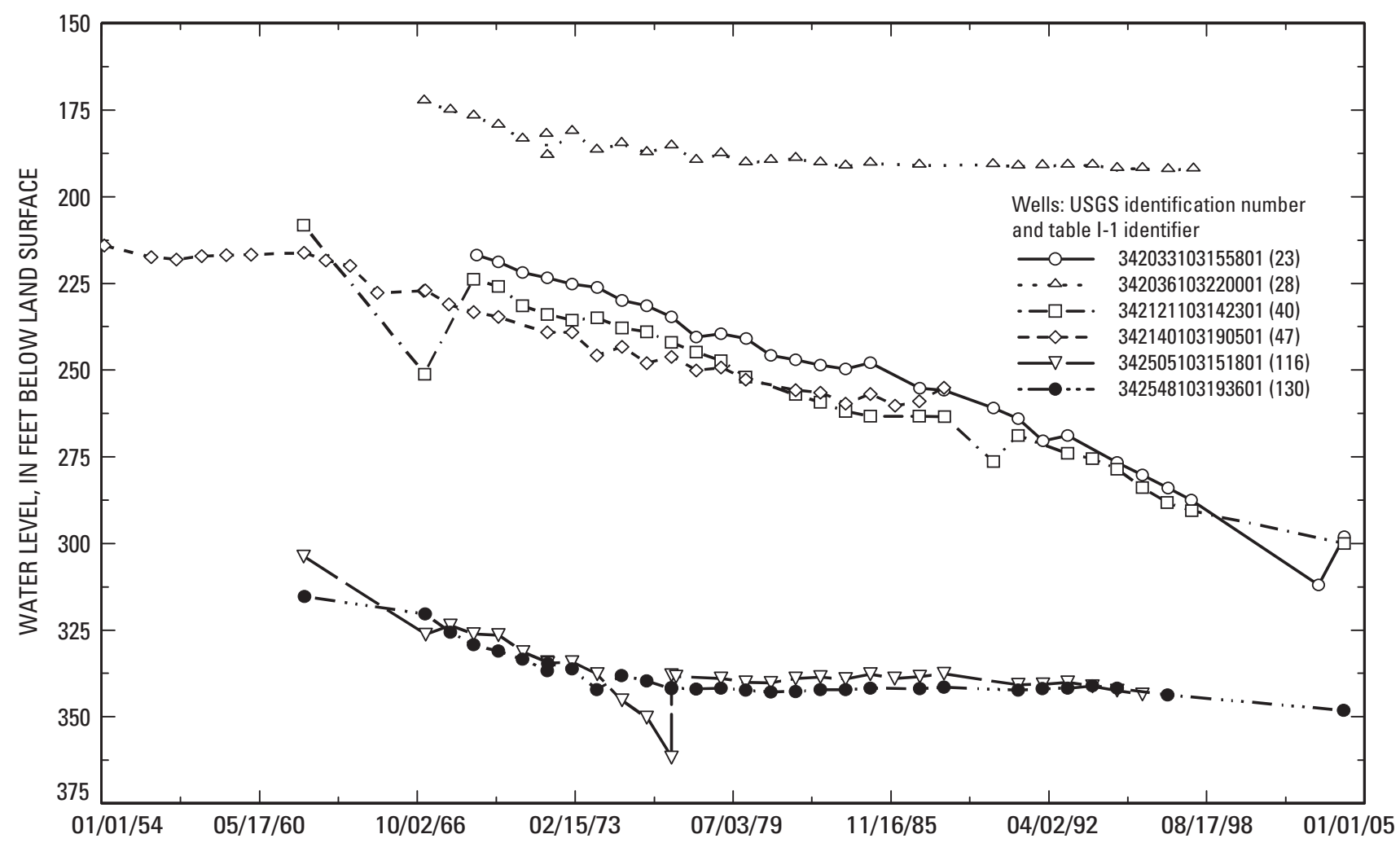

Figure 4. Water level in wells with the longest periods of record in the area surrounding Cannon Air Force Base, $1954-2004$.

from the previously used lagoons and the current disposal area (Playa Lake). For all wells with at least three data points and a minimum 3-year period of record, the decline in water levels near Landfill 5 and the Sewage Lagoons was strongly linear $\left(\mathrm{R}^{2}\right.$ greater than 0.75) indicating a regional influence that is causing water levels to decline (table 8).

A seasonal variation in water levels was observed in wells $\mathrm{C}, \mathrm{D}$, and $\mathrm{S}$, which are adjacent to the southern boundary of Cannon AFB and near an irrigation well immediately south of the base boundary (fig. 2). No production wells for the base are located in this area. Water levels in C, D, and S indicated a pattern of water-level decline during the summer irrigation season followed by a partial water-level recovery during winter (fig. 5). This water-level pattern, however, was not readily apparent or was absent in wells A and Q, which are about 0.4 mi north-northwest of the irrigation well. The influence (cone of depression) of the irrigation well south of the base boundary does not appear to extend beyond the Landfill 5 area.

\section{Saturated Interval of Wells at Landfill 5 and the Sewage Lagoons}

The saturated thickness of the Southern High Plains aquifer has decreased at Cannon AFB because of declining water levels (table 7). Wells near Landfill 5 and the Sewage Lagoons with periods of records from the beginning of
USGS monitoring indicated decreases equal to or greater than 18 percent in the saturated interval (table 9). The largest declines in water level and largest decreases in saturated interval occurred near Landfill 5 (wells A and B).

\section{Aquifer Recharge}

Soil- and ground-water chemistry data collected by the USGS in 2004 for a recharge study was used to determine possible recharge rates and to estimate the ground-water age of the Southern High Plains aquifer at Cannon AFB (Falk, 2005). Chloride concentrations and moisture content of soil samples were analyzed to determine the water infiltration rate through the soil profile and the time required for chloride accumulation. Large chloride concentrations in soil water and long accumulation rates in interplaya areas indicated that diffuse recharge likely is not occurring at Cannon AFB, but small chloride concentrations in soil water below a stormwater detention area indicated that focused recharge is likely contributing to the aquifer (Falk, 2005). Additionally, concentrations of chlorofluorocarbons in ground water were measured to determine the apparent age of the water. The apparent ages, which are model ages uncorrected for physical and chemical processes that can affect chlorofluorocarbon concentrations (Plummer and Busenberg, 2000), ranged from 25 to 50 years old. The presence of chlorofluorocarbons in ground water indicates that the aquifer has been recharged since the 1940s, 
Table 8. Measurements and changes in water level for wells near Landfill 5 and the Sewage Lagoons at Cannon Air Force Base, 1994-2005.

$\left[\mathrm{R}^{2}\right.$, statistical value that describes the proportion of variation in the data explained by the least-squares regression model—water level relative to time); NA, not applicable—data set has less than 3 years of record]

\begin{tabular}{|c|c|c|c|c|c|c|c|}
\hline $\begin{array}{l}\text { U.S. Geological Survey } \\
\text { identification } \\
\text { number }\end{array}$ & $\begin{array}{l}\text { Well } \\
\text { Identifier } \\
\text { (fig. 2) }\end{array}$ & $\begin{array}{c}\text { First } \\
\text { measurement }\end{array}$ & $\begin{array}{c}\text { Last } \\
\text { measurement }\end{array}$ & $\begin{array}{l}\text { Number of } \\
\text { measure- } \\
\text { ments }\end{array}$ & $\begin{array}{c}\text { Water-level } \\
\text { change } \\
\text { (feet } \\
\text { per year) } \\
\end{array}$ & $\begin{array}{c}\text { Water-level } \\
\text { change during } \\
\text { period of record }{ }^{1} \\
\text { (feet) }\end{array}$ & $\mathbf{R}^{2}$ \\
\hline 342218103182601 & A & $02 / 21 / 94$ & 01/10/05 & 16 & -2.46 & -27.06 & 1.00 \\
\hline 342203103181001 & B & $02 / 21 / 94$ & 01/10/05 & 35 & -2.97 & -32.64 & 0.98 \\
\hline 342156103180801 & C & $04 / 06 / 98$ & 01/10/05 & 14 & -2.29 & -16.06 & 0.82 \\
\hline 342157103181701 & D & 03/02/99 & 01/10/05 & 13 & -2.24 & -13.46 & 0.93 \\
\hline 342328103182401 & $E$ & 09/13/94 & 01/10/05 & 20 & -1.59 & -17.44 & 0.98 \\
\hline 342321103181001 & $\mathrm{~F}$ & $09 / 12 / 94$ & 01/10/05 & 20 & -1.60 & -17.65 & 0.96 \\
\hline 342313103180801 & G & $09 / 13 / 94$ & 01/10/05 & 19 & -1.64 & -18.02 & 0.98 \\
\hline 342307103181601 & $\mathrm{H}$ & $09 / 13 / 93$ & 01/10/05 & 20 & -1.55 & -18.65 & 0.98 \\
\hline 342158103180601 & I & $02 / 21 / 94$ & $02 / 28 / 00$ & 15 & -3.21 & -19.28 & 0.98 \\
\hline 342201103180901 & $\mathrm{~L}$ & $02 / 21 / 94$ & 08/19/97 & 10 & -4.01 & -12.03 & 0.99 \\
\hline 342200103181001 & M & $02 / 21 / 94$ & 08/06/98 & 11 & -2.60 & -10.40 & 0.96 \\
\hline 342317103174701 & $\mathrm{~N}$ & $06 / 27 / 95$ & 01/10/05 & 8 & -1.45 & -14.45 & 0.95 \\
\hline 342300103175001 & Oa & $02 / 29 / 04$ & 01/10/05 & 5 & NA & -2.53 & NA \\
\hline 342304103174401 & 0 & $06 / 27 / 95$ & $02 / 27 / 96$ & 2 & NA & -0.06 & NA \\
\hline 342309103180601 & $P$ & $07 / 15 / 95$ & $06 / 25 / 96$ & 6 & NA & -2.34 & NA \\
\hline 342310103180801 & $\mathrm{~Pa}$ & $02 / 27 / 04$ & 01/10/05 & 5 & NA & -2.37 & NA \\
\hline 342219103183101 & 0 & $11 / 19 / 96$ & 08/19/03 & 17 & -2.69 & -18.86 & 0.98 \\
\hline 342323103180801 & Ra & $05 / 26 / 04$ & 01/10/05 & 4 & NA & -0.55 & NA \\
\hline 342157103181101 & $S$ & 03/02/99 & 01/10/05 & 15 & -2.43 & -14.56 & 0.93 \\
\hline 342200103180901 & $\mathrm{~T}$ & 03/02/99 & 01/10/05 & 14 & -2.37 & -14.19 & 0.97 \\
\hline 342205103181001 & U & 03/02/99 & 01/10/05 & 14 & -2.28 & -13.68 & 0.98 \\
\hline 342418103201201 & V & $11 / 06 / 03$ & $01 / 10 / 05$ & 7 & NA & -0.44 & NA \\
\hline 342348103175801 & W & $02 / 27 / 04$ & $01 / 10 / 05$ & 8 & NA & -3.84 & NA \\
\hline 342222103194301 & $X$ & $03 / 11 / 04$ & $01 / 10 / 05$ & 5 & NA & 0.14 & NA \\
\hline
\end{tabular}

${ }^{1}$ Periods of record beginning and ending dates differ among wells, which can affect comparison of water-level changes.

Table 9. Change in saturated interval for selected wells at Cannon Air Force Base.

\begin{tabular}{cccccccc}
\hline $\begin{array}{c}\text { U.S. Geological } \\
\text { Survey } \\
\text { identification } \\
\text { number }\end{array}$ & $\begin{array}{c}\text { Well } \\
\text { identifier } \\
\text { (fig. 2) }\end{array}$ & $\begin{array}{c}\text { Initial water-level } \\
\text { measurement date }\end{array}$ & $\begin{array}{c}\text { Final water-level } \\
\text { measurement date }\end{array}$ & $\begin{array}{c}\text { Initial } \\
\text { saturated } \\
\text { interval } \\
\text { (feet) }\end{array}$ & $\begin{array}{c}\text { Final } \\
\text { saturated } \\
\text { interval } \\
\text { (feet) }\end{array}$ & $\begin{array}{c}\text { Overall } \\
\text { decrease } \\
\text { (feet) }\end{array}$ & $\begin{array}{c}\text { Overall } \\
\text { decrease } \\
\text { (percent) }\end{array}$ \\
\hline 342218103182601 & $\mathrm{~A}$ & $02 / 21 / 94$ & $01 / 10 / 05$ & 76.2 & 49.1 & 27.1 & 35.6 \\
342203103181001 & $\mathrm{~B}$ & $02 / 21 / 94$ & $01 / 10 / 05$ & 91.7 & 59.1 & 32.6 & 35.5 \\
342328103182401 & $\mathrm{E}$ & $09 / 13 / 94$ & $01 / 10 / 05$ & 92.4 & 75.0 & 17.4 & 18.8 \\
342321103181001 & $\mathrm{~F}$ & $09 / 12 / 94$ & $01 / 10 / 05$ & 98.0 & 80.4 & 17.6 & 18.0 \\
342313103180801 & $\mathrm{G}$ & $09 / 13 / 94$ & $01 / 10 / 05$ & 92.7 & 74.7 & 18.0 & 19.4 \\
342307103181601 & $\mathrm{H}$ & $09 / 13 / 93$ & $01 / 10 / 05$ & 96.6 & 77.9 & 18.7 & 19.4 \\
\hline
\end{tabular}

${ }^{1}$ Well depth and depth to water from land surface were used to calculate saturated interval. 


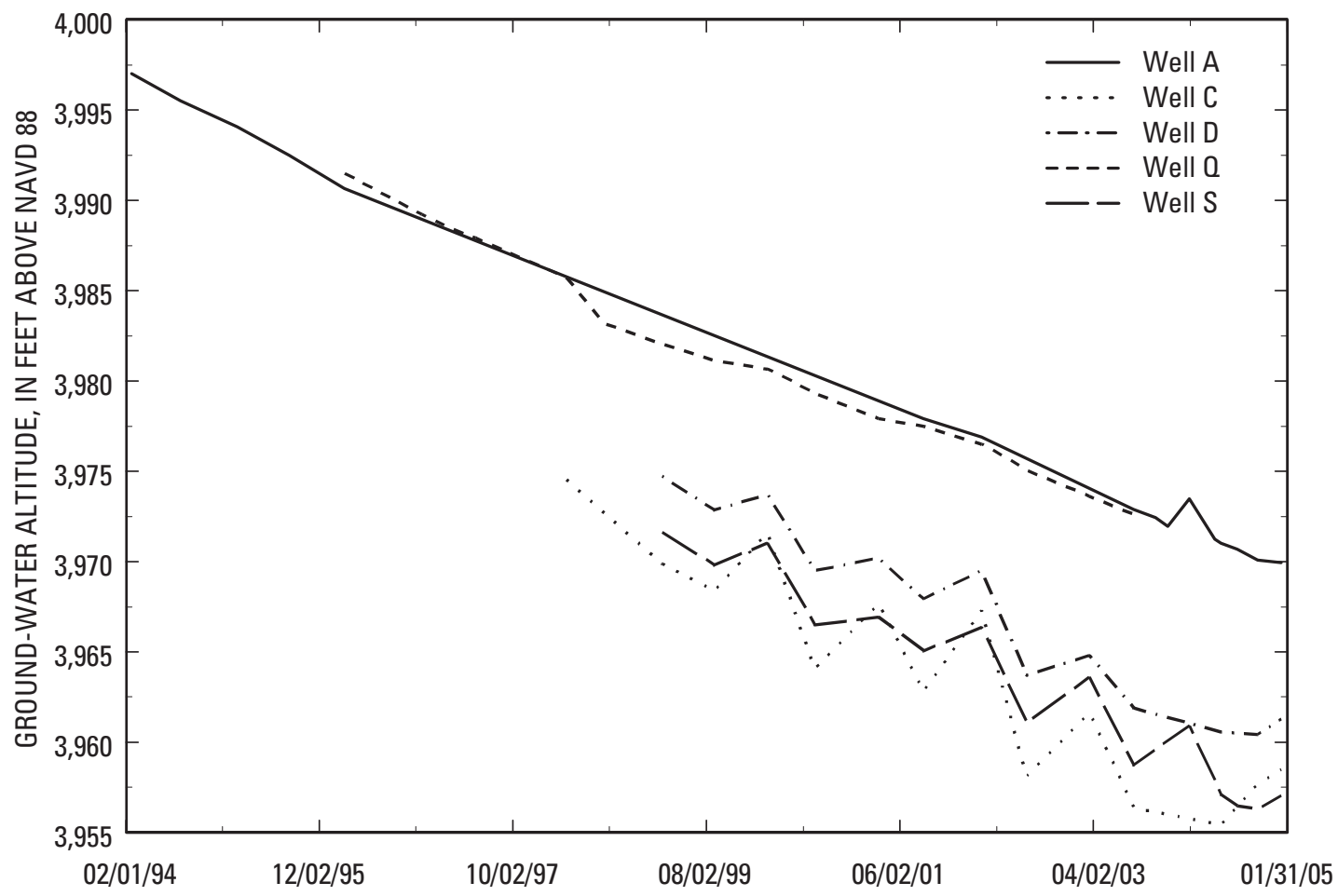

Figure 5. Water-level seasonal fluctuations in selected monitoring wells at Cannon Air Force Base, 1994-2005.

but the water likely is a mixture of this young water and older water that did not contain chlorofluorocarbons (Falk, 2005).

\section{Ground-Water Quality}

Water-quality sampling by the USGS at Cannon AFB has been dictated by RCRA and NPDES requirements. Samples collected at the wells were for analysis of specified compounds at each site as required by the State of New Mexico under RCRA and NPDES regulations. Because of this sampling scheme, water-quality data between well groups is not consistent (Sewage Lagoons compared with Landfill 5) and few data are available for interpretation of water composition.

All USGS data are presented as total concentrations from raw (pretreatment) ground-water samples. All SDWA waterquality standards are applicable to posttreatment samples that meet the turbidity requirement of the SDWA. Drinking-water standards are applicable to samples with a turbidity equal to or less than 5 nephelometric turbidity units (NTU) and typically have a turbidity of 1 NTU or less (U.S. Environmental Protection Agency, 2005b). Turbidity values were not collected by the USGS at Cannon AFB. It is possible that the total concentrations at Cannon AFB included a concentration fraction that resulted from suspended material that would not have been present if samples were treated (such as filtering or settling). Comparison of concentrations from pretreatment and posttreatment samples can be misleading, and any total concentrations greater than the standards should be judged with caution.

\section{Anthropogenic Compounds}

Analyses for anthropogenic compounds, including organic halogens, volatile organic compounds, semivolatile organic compounds, dioxins, furans, polynuclear aromatic hydrocarbons, organochlorine pesticides, polychlorinated biphenyls, and chlorinated herbicides, have been conducted for samples collected from Landfill 5 and the Sewage Lagoons wells since 1994. The maximum total concentrations of these compounds were small and less than USEPA drinking-water standards (table 10). Anthropogenic compounds that have been detected were pesticide or industrial compounds (table 10), and at least one anthropogenic compound was detected in each monitoring well. Private contractor sampling at wells N, O, $\mathrm{Oa}, \mathrm{P}, \mathrm{Pa}, \mathrm{R}$, and Ra did not detect anthropogenic compounds from 2001 to 2004 (Bhate Environmental Associates, Inc., 2002a, 2002b, 2003a, 2003b, 2004, 2005). Base productionwell sampling in 2005 indicated the presence of a small number of pesticide or industrial compounds in wells $3,4,7$, and 12, at concentrations less than drinking-water standards (C.M. Bohler, U.S. Air Force, written commun., 2005).

The detection of anthropogenic compounds in ground water indicates the presence of modern water (recharged since 1940s) in the Southern High Plains aquifer at Cannon AFB. The presence of these compounds does not indicate recharge at a well site, as the compounds may have traveled from an upgradient location. The number of compounds detected in ground water from well $\mathrm{F}$ likely indicates infiltration and 
Table 10. Maximum concentrations of anthropogenic compounds detected in ground-water samples collected by the U.S. Geological Survey at Cannon Air Force Base, 1994-2004.

[All concentrations are in micrograms per liter, and all results are total (unfiltered) concentrations; "Use" is the general use of the compound. Compounds may have multiple uses, but a general category of use is presented for differentiating between compounds. The "industrial" use indicates the compound is used for making other compounds or is an additive in other compounds. "---" indicates the compound description is too generic for a determination of general use]

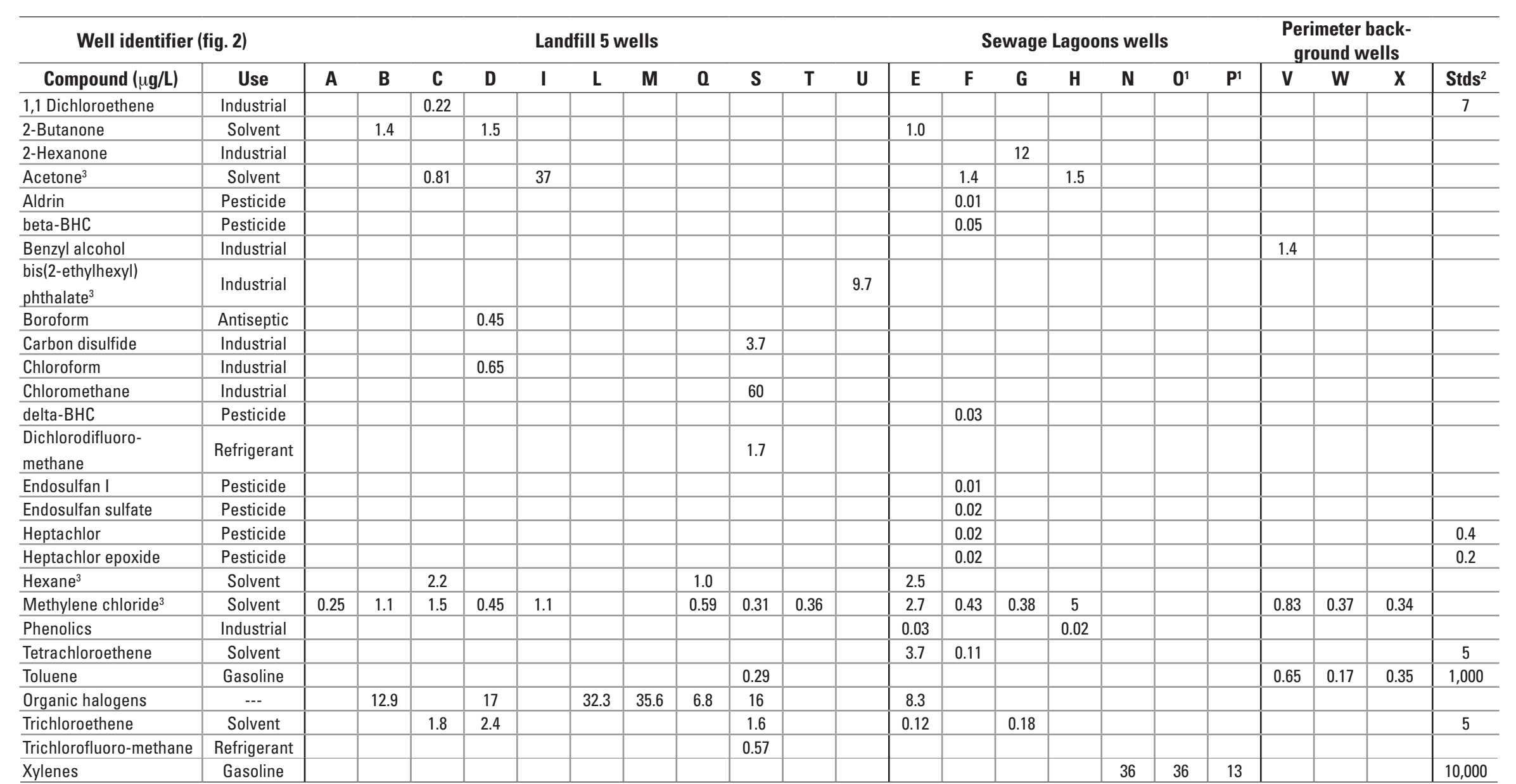

${ }^{1}$ Includes samples from wells $\mathrm{O}$ and $\mathrm{Oa}$ and $\mathrm{P}$ and $\mathrm{Pa}$.

${ }^{2}$ Standards: primary drinking-water standards as issued by the U.S. Environmental Protection Agency for National Primary Drinking Water Regulations (U.S. Environmental Protection Agency, 2005b).

Standards are for posttreatment samples.

${ }^{3}$ Common sampling/laboratory-associated compounds that have been detected in field-equipment- and method-blank samples on occasion. 
movement of treated wastewater from the Sewage Lagoons to the underlying aquifer. The presence of a diverse group of industrial- and agriculture-related compounds may indicate anthropogenic influences from on and off the base. Additionally, some of the contaminants are common sampling/laboratory-associated compounds such as acetone, bis(2-ethylhexyl) phthalate, hexane, and methylene chloride that may have been introduced to the sample during collection or analysis (small concentrations of these compounds have been found in fieldequipment- and method-blank samples on occasion).

\section{Perchlorate}

The anthropogenic use of perchlorate is as a propellant, but perchlorate has been detected in ground water in northwest Texas where no known anthropogenic source(s) exists (Jackson and others, 2003). Further investigation of perchlorate in northwestern Texas and eastern New Mexico has produced evidence indicating that perchlorate in this area likely is from a natural source and probably is atmospherically deposited (Rajagopalan and others, 2006). Atmospheric processes such as the interaction of chloride and ozone can produce perchlorate naturally (Dasgupta and others, 2005). With wet or dry deposition, perchlorate can accumulate in the soil and subsequently be transported to an aquifer in detectable concentrations. The increasing analytical capability to detect perchlorate at small concentrations has allowed the identification of its likely natural presence in parts of New Mexico (Plummer and others, 2006) and northwest Texas (Rajagopalan and others, 2006).

Perchlorate was detected in at least one sample from every well at Cannon AFB for which perchlorate was analyzed (table 11). The number of perchlorate detections was largest in June 2004 because of the use of a newer analytical method (SW846 8321A; U.S. Environmental Protection Agency, 1986 [revision]) with a lower method detection level than that of the previous method (EPA 314.0; U.S. Environmental Protection Agency, 1999). Using the newer analytical method, concentrations of perchlorate in ground water at Cannon AFB ranged from 0.21 to $5.6 \mu \mathrm{g} / \mathrm{L}$. These concentrations are similar to perchlorate concentrations detected in eastern New Mexico and northwest Texas by Rajagopalan and others (2006) that were largely attributed to a natural, atmospheric source. The wide distribution of perchlorate at small concentrations at Cannon AFB also appears to indicate a natural, atmospheric source. The variation in perchlorate concentrations between ground-water samples from the various wells may be related to recharge and flow paths in the aquifer.

Regulation of perchlorate (contaminant candidate) is being considered by the USEPA under the SDWA. The USEPA has not set a maximum contaminant level for perchlorate, but California has set a public health goal of $6 \mathrm{ppb}$ for dissolved concentrations (Council on Water Quality, 2005). Other States have set advisory levels for drinking water, and the USEPA has established an official reference dose of $0.0007 \mathrm{mg} / \mathrm{kg} /$ day of perchlorate that translates to a drinking-water equivalent level of 24.5 ppb (U.S. Environmental Protection Agency, 2005a). Only perchlorate concentrations in samples from well $\mathrm{T}$ (estimated values because of chloride interference) were greater than California's public health goal, and these results occurred when the previous, less accurate analytical method was used (table 11). Perchlorate concentrations in samples from well T using the newer analytical method resulted in concentrations smaller than California's public health goal (assuming equivalent units).

\section{Trace Elements}

Total trace-element concentrations in raw ground water at Cannon AFB generally were less than USEPA primary and secondary drinking-water standards (U.S. Environmental Protection Agency, 2005b). Maximum total concentrations of aluminum, iron, and manganese exceeded secondary drinking-water standards, and maximum chromium concentrations exceeded the primary drinking-water standard (fig. 6). It is possible that trace-element concentrations in raw (pretreatment and unfiltered) samples collected at Cannon AFB included a concentration fraction that resulted from suspended material. Comparison of concentrations from pretreatment and posttreatment samples can be misleading, and any total concentrations greater than the standards should be judged with caution.

At least one sample exceeded the aluminum secondary drinking-water standard of $50 \mu \mathrm{g} / \mathrm{L}$ for every well at Cannon AFB for which ground water was analyzed for aluminum (fig. 7). In ground water from wells B, D, F, H, I, L, M, and Q, at least one iron concentration exceeded the secondary drinking-water standard of $300 \mu \mathrm{g} / \mathrm{L}$ (fig. 8). Water-quality data from contractor sampling indicate that ground water from wells $\mathrm{N}, \mathrm{O}, \mathrm{Oa}, \mathrm{R}$, and $\mathrm{Ra}$ (Sewage Lagoons) also have exceeded the 300- $\mu \mathrm{g} / \mathrm{L}$ secondary standard for iron (Parallax, Inc., 2000; Bhate Environmental Associates, Inc., 2002a, 2002b, 2004, and 2005). One manganese concentration exceeded the secondary drinking-water standard of $50 \mu \mathrm{g} / \mathrm{L}$ in ground water collected from wells $\mathrm{H}$ and Q (fig. 9). One sample from well Ra (not shown in fig. 9, contractor data not compiled with USGS data) sampled by a private contractor also exceeded the secondary drinking-water standard for manganese (Bhate Environmental Associates, Inc., 2002b). In ground water from wells L and M (Landfill 5), one chromium concentration exceeded the primary drinking-water standard of $100 \mu \mathrm{g} / \mathrm{L}$ (fig. 10). Ground water collected from production wells in 2002 by a contractor contained small concentrations of arsenic, barium, chromium, nickel, and selenium that were smaller than drinkingwater standards (Earth Tech, Inc., 2005).

\section{Nitrate and Organic Carbon}

Results of total nitrate (nitrate plus nitrite or nitrate) analysis indicate that only ground water from wells $G$ and $\mathrm{P}$ (Sewage Lagoons) exceeded the posttreatment USEPA (2005b) primary drinking-water standard of $10 \mathrm{mg} / \mathrm{L}$ (fig. 11). These larger concentrations were likely a result of infiltrated 
Table 11. Perchlorate concentrations in ground water at Cannon Air Force Base.

[MDL, method detection level; RL, reporting level; E, estimated; all concentrations in micrograms per liter and all results are total concentrations]

\begin{tabular}{|c|c|c|c|c|c|}
\hline Well identifier (fig. 2) & Mar 2001 & Aug 2002 & Mar 2003 & Aug 2003 & June 2004 \\
\hline & \multicolumn{2}{|c|}{$M D L=5, R L=20$} & \multicolumn{2}{|c|}{$M D L=0.2, R L=1$} & $M D L=0.0012, R L=0.01$ \\
\hline A & & & & & 2.4 \\
\hline B & & $5.0 \mathrm{E}$ & 2.1 & 2.4 & 2.3 \\
\hline C & & & & & 0.41 \\
\hline D & & & & & 0.21 \\
\hline$E$ & & & 1.7 & & 1.8 \\
\hline $\mathrm{F}$ & & & 2.3 & & 2.2 \\
\hline G & & & 1.7 & & 1.7 \\
\hline $\mathrm{H}$ & & & 2.4 & & 2.6 \\
\hline 0 & $5.8 \mathrm{E}$ & & 2.2 & & \\
\hline$S$ & & $4.6 \mathrm{E}$ & 2.4 & 2.9 & 2.7 \\
\hline$T$ & $19.9 \mathrm{E}$ & $6.5 \mathrm{E}$ & 2.3 & 2.7 & 2.3 \\
\hline U & & & 2.3 & 2.4 & 2.3 \\
\hline V & & & & & 5.6 \\
\hline W & & & & & 0.63 \\
\hline $\mathrm{x}$ & & & & & 1.1 \\
\hline
\end{tabular}

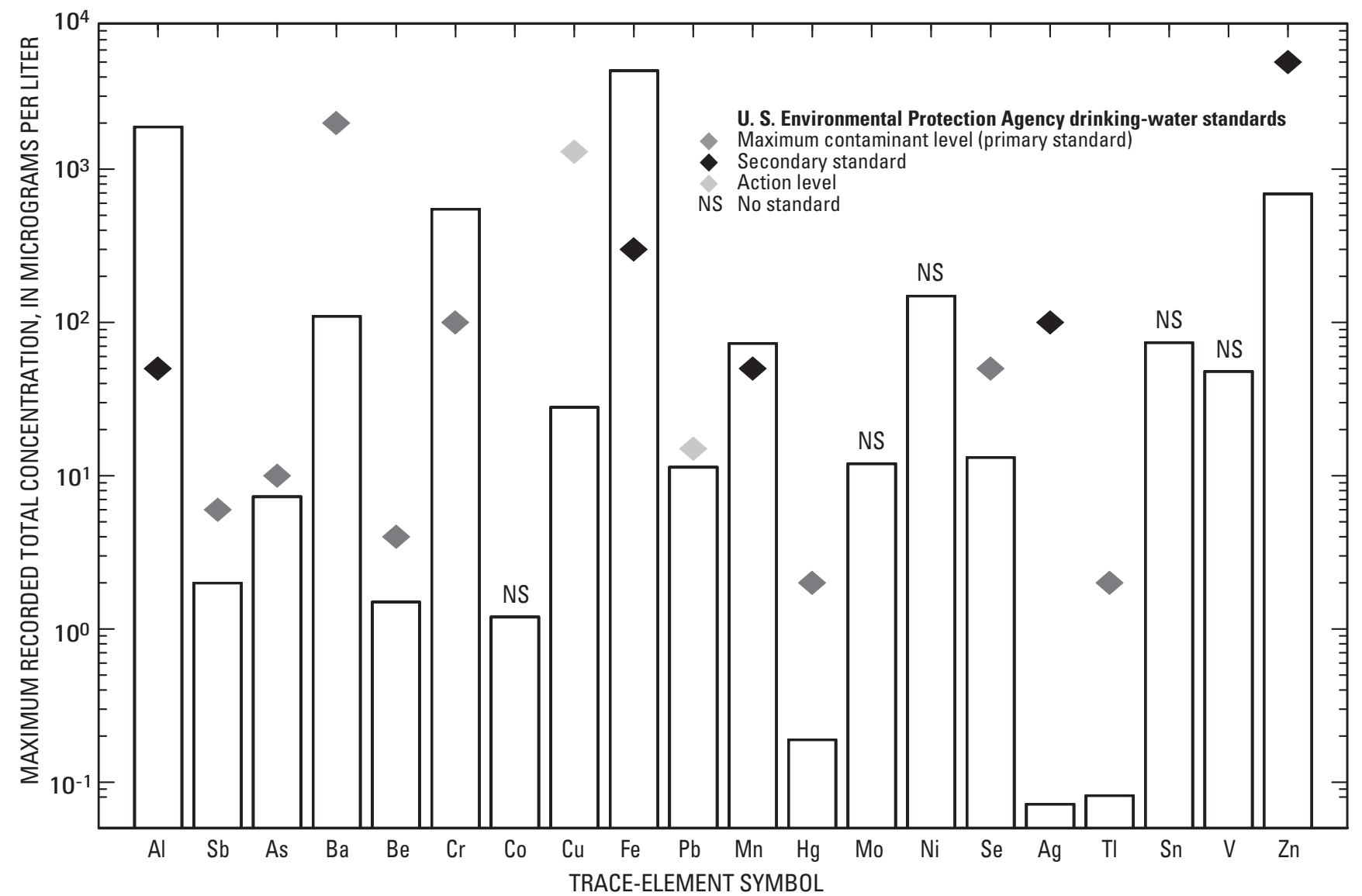

Figure 6. Maximum recorded total trace-element concentrations in ground water at Cannon Air Force Base, 1994-2004, and U.S. Environmental Protection Agency (2005b) drinking-water standards. 


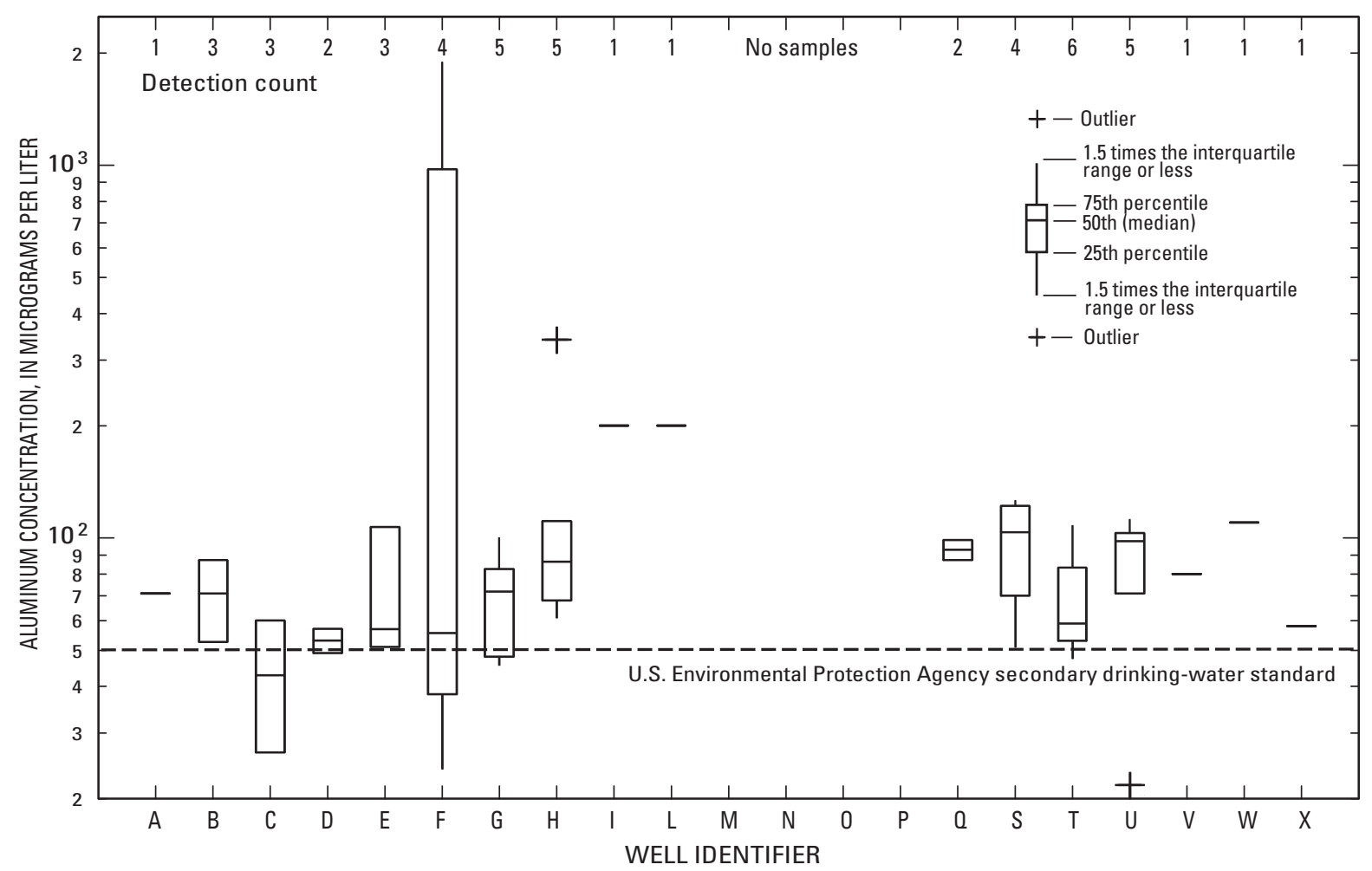

Figure 7. Aluminum concentrations in ground water at Cannon Air Force Base, 1994-2004.

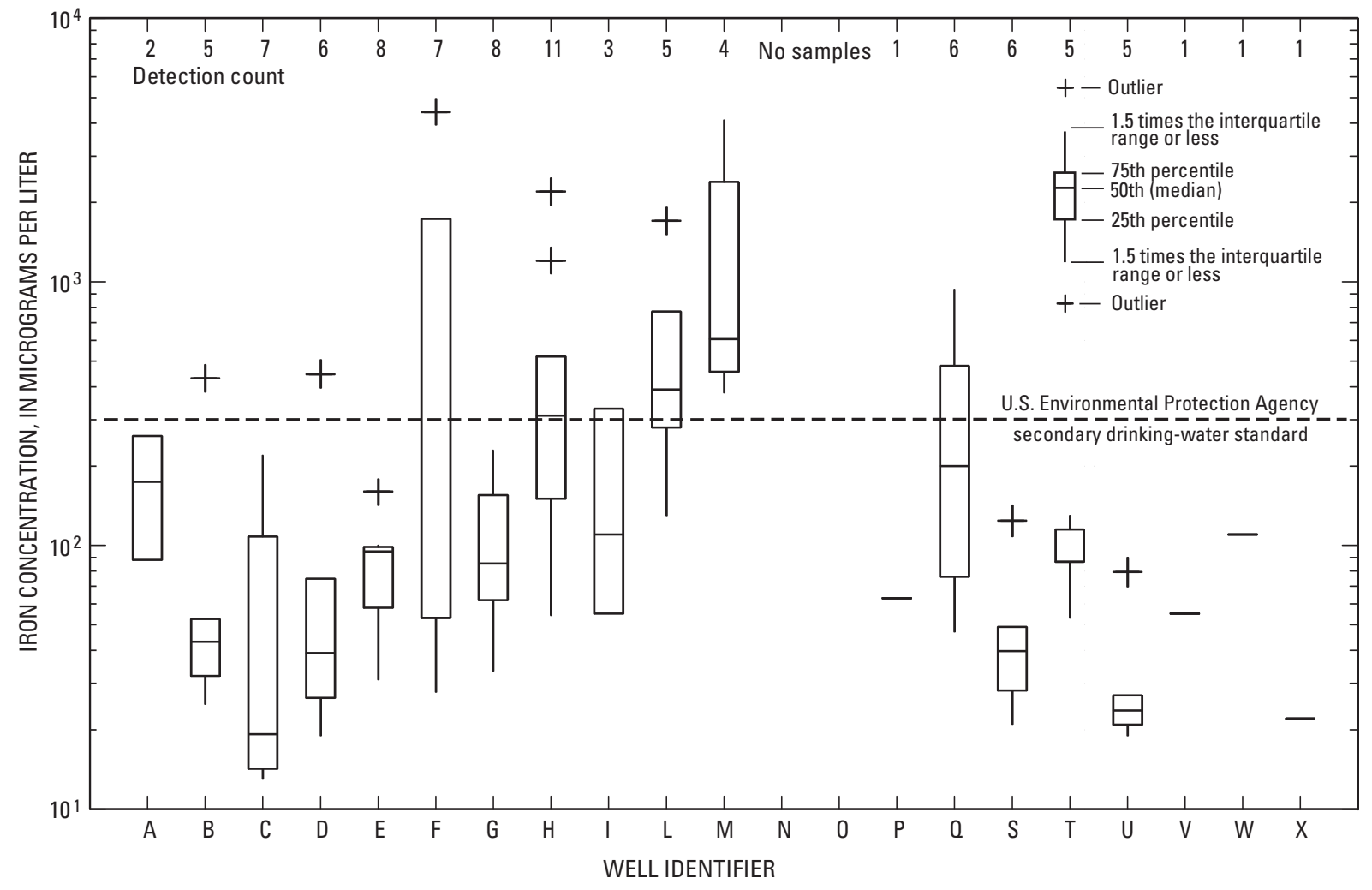

Figure 8. Iron concentrations in ground water at Cannon Air Force Base, 1994-2004. 


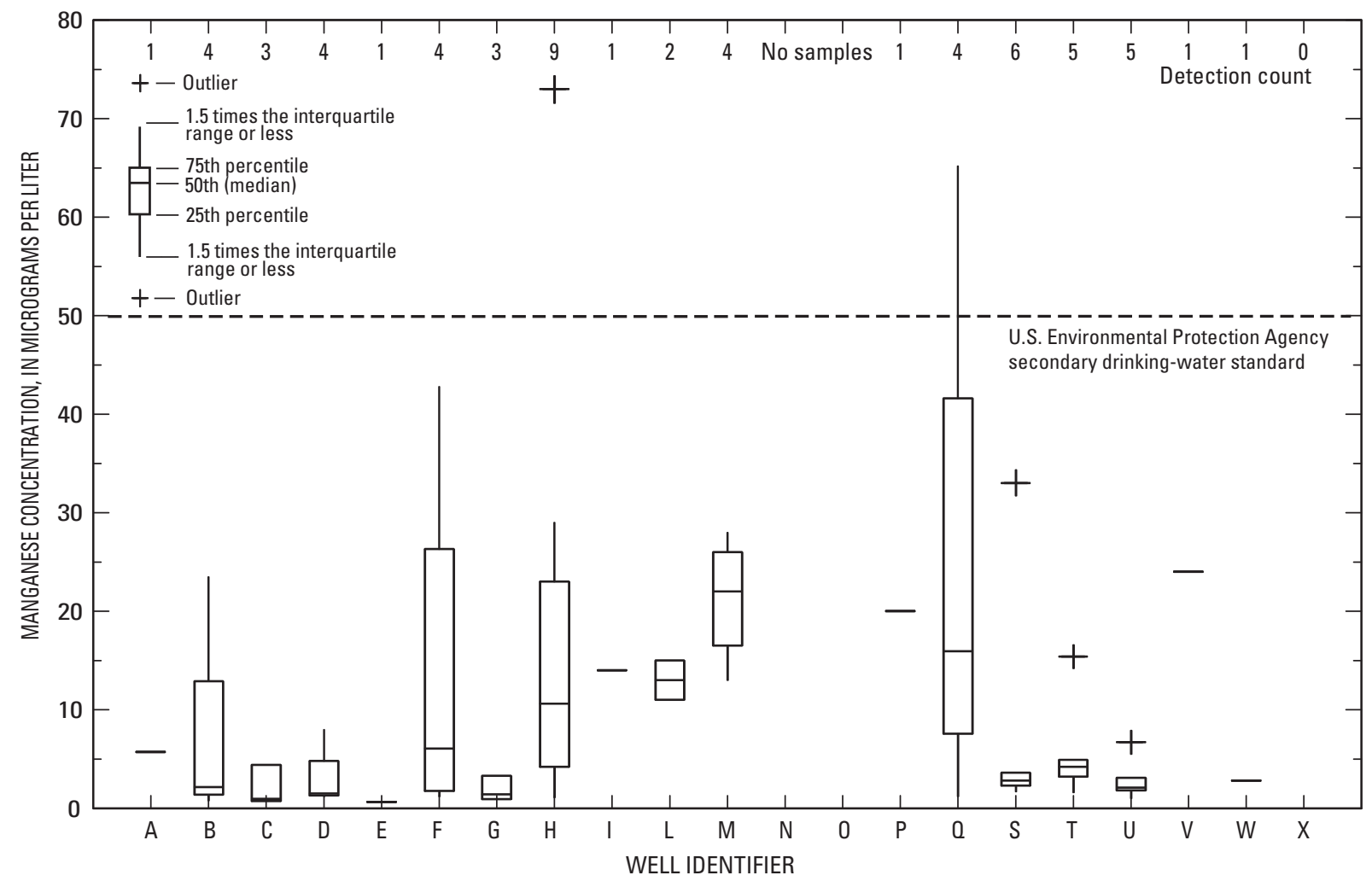

Figure 9. Manganese concentrations in ground water at Cannon Air Force Base, 1994-2004.

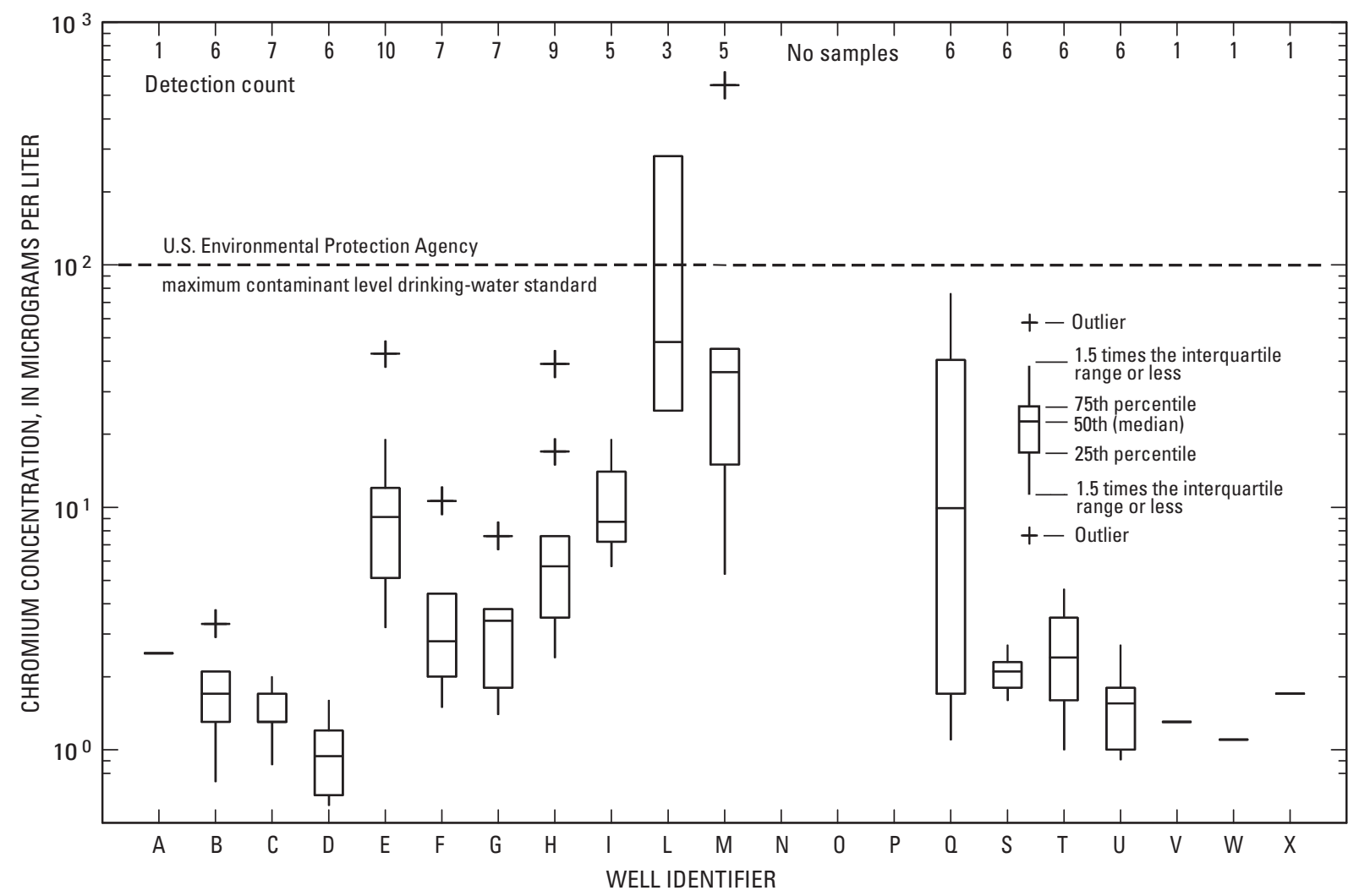

Figure 10. Chromium concentrations in ground water at Cannon Air Force Base, 1994-2004. 


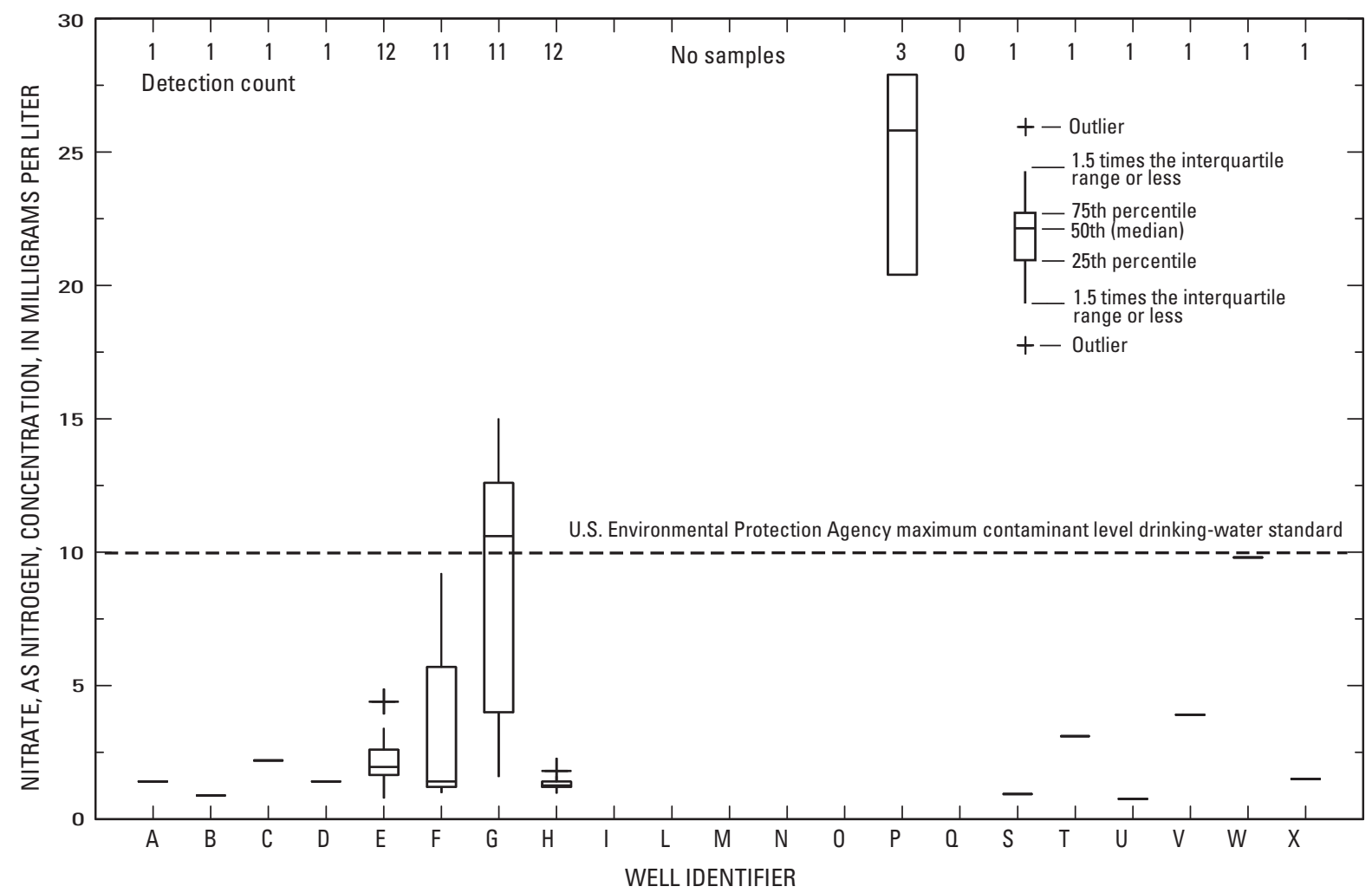

Figure 11. Total nitrate, as nitrogen, concentrations in ground water at Cannon Air Force Base, 1994-2004.

treated wastewater. Data for wells near the Sewage Lagoons (E-H) have a sufficient temporal scale to observe the influence and decline of nitrate concentrations due to infiltrated wastewater. From 1994 to 2004, nitrate concentrations in ground water near the Sewage Lagoons decreased before and after decommissioning (lagoons were decommissioned in 1998, but inflow was reduced and halted before this date) to concentrations in wells not affected by the lagoons (fig. 12).

Concentrations of total organic carbon (TOC) were generally near or less than $1 \mathrm{mg} / \mathrm{L}$ in ground water at Cannon AFB (fig. 13). One detection of TOC in ground water from well $\mathrm{F}$ in 2004 was at a concentration of $9.5 \mathrm{mg} / \mathrm{L}$. Ground water from well $\mathrm{F}$ did not previously contain a detectable concentration of TOC, and the reason for the large TOC concentration is unknown. Ground water collected in 2005 from production wells at the base either contained no detectable TOC or a concentration less than $1 \mathrm{mg} / \mathrm{L}$ (C.M. Bohler, U.S. Air Force, written commun., 2005).

\section{Major lons}

Alkalinity or carbonate species concentrations have not been analyzed as part of USGS water-quality sampling at Cannon AFB, but a full set of major-ion concentrations for ground water at wells D, E, V, W, and X (fig. 2) was recorded as part of a recharge investigation conducted by the USGS at the base in 2004 (Falk, 2005). Different water compositions were present in different parts of the base, and chloride concentrations varied substantially (fig. 14). Samples from wells E, V, and W were a calcium/magnesium-sulfate water type (per Back's [1961] classification diagram), and samples from wells $\mathrm{D}$ and $\mathrm{X}$ were a calcium/magnesium-bicarbonate water type.

Calcium and sulfate were analyzed for samples collected in June 2004 from most of the wells at Cannon AFB. Differences in the ratio of these ions in ground water (fig. 15) may be indicative of multiple source waters with different recharge areas or leakage of water from the Chinle Formation into the Ogallala Formation, although such differences could be from an anthropogenic source(s). Calcium and sulfate concentrations from June 2004 illustrate some linearity indicating the possible mixing of different source waters represented by ground water from wells $\mathrm{V}$ and $\mathrm{X}$. Wells $\mathrm{D}, \mathrm{E}$, and $\mathrm{W}$ do not conform to this scenario, and calcium concentration varies substantially among the middle grouping of wells (fig. 15).

Examination of major cation to sulfate ratios for the June 2004 data provides further indication of multiple source waters or other influences on ground water in the Southern High Plains aquifer at Cannon AFB. Similar cation/sulfate ratios indicating similar source waters were present for samples from nearly all wells, except for samples from wells C, D, E, and $X$ (fig. 16). Wells $C, D$, and $X$ are located along the southern boundary of Cannon AFB, but wells A, S, T, and $\mathrm{U}$ are also located in this area and water from these wells did not contain the larger cation/sulfate ratios that are apparent for wells C, D, and X. Samples from wells A, S, T, and U did indicate variable concentrations of calcium and sulfate (fig. 15). A difference in 


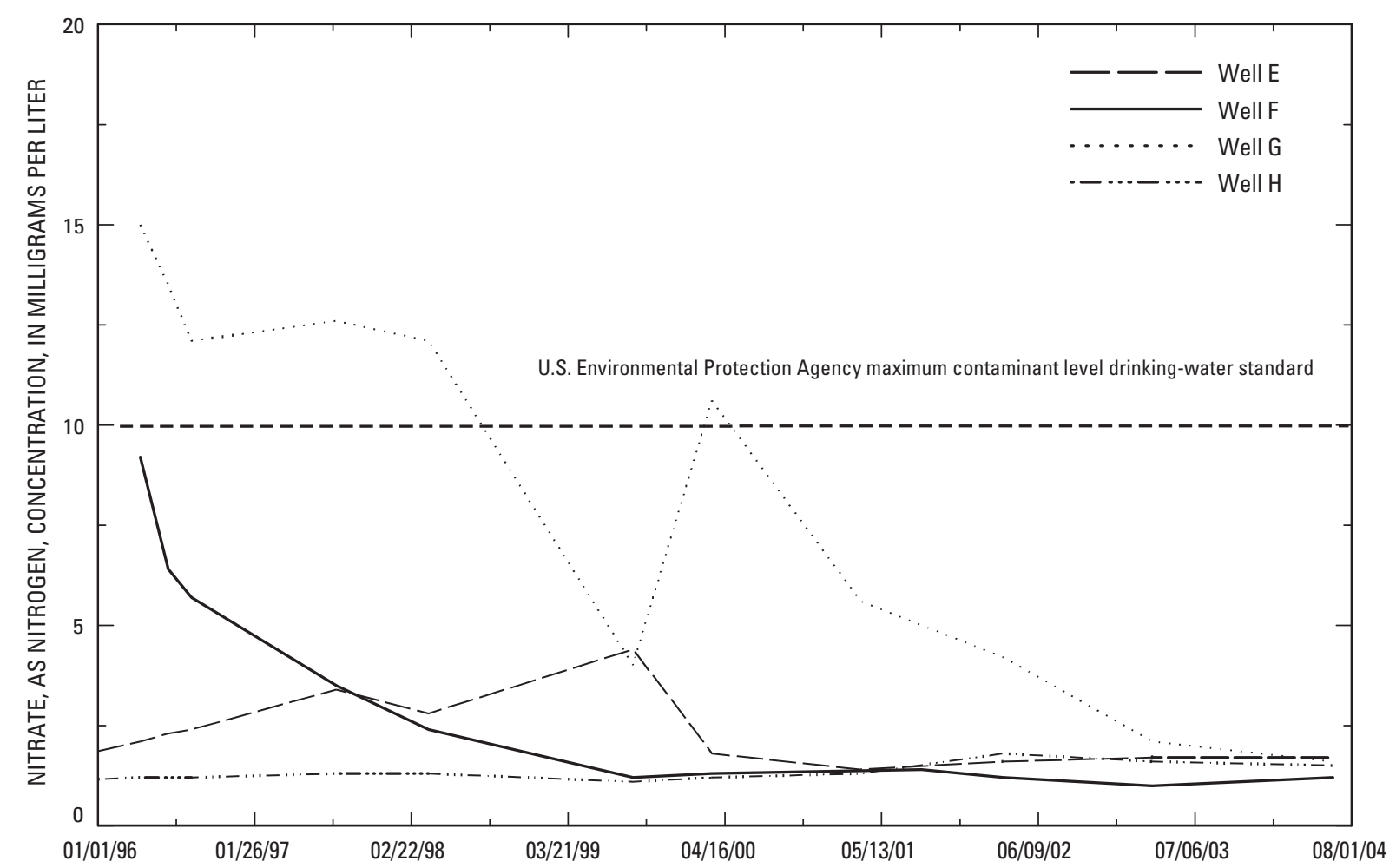

Figure 12. Total nitrate, as nitrogen, concentrations in ground water from wells near the Sewage Lagoons at Cannon Air Force Base, 1996-2004

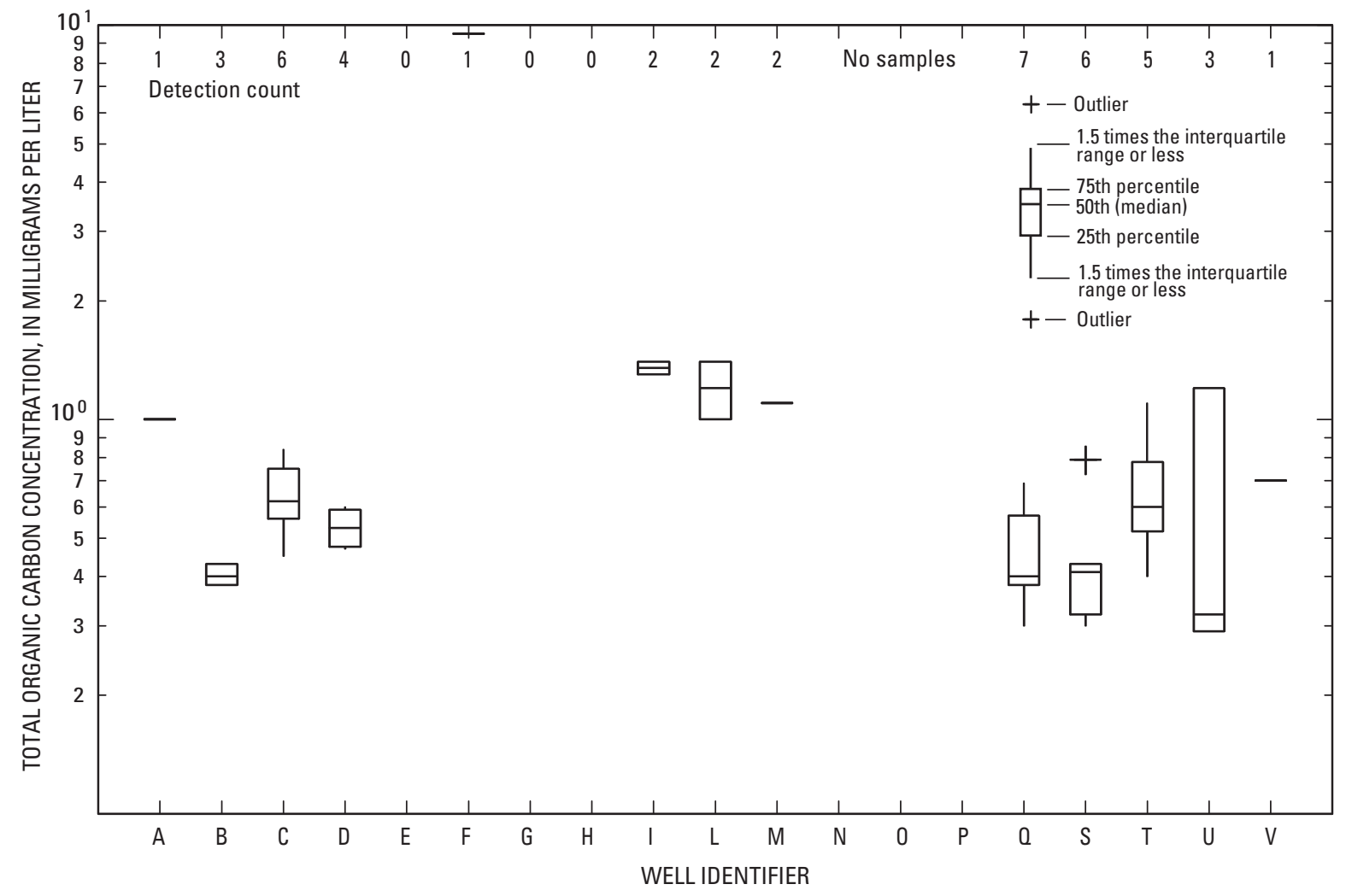

Figure 13. Total organic carbon concentrations in ground water at Cannon Air Force Base, 1994-2004 


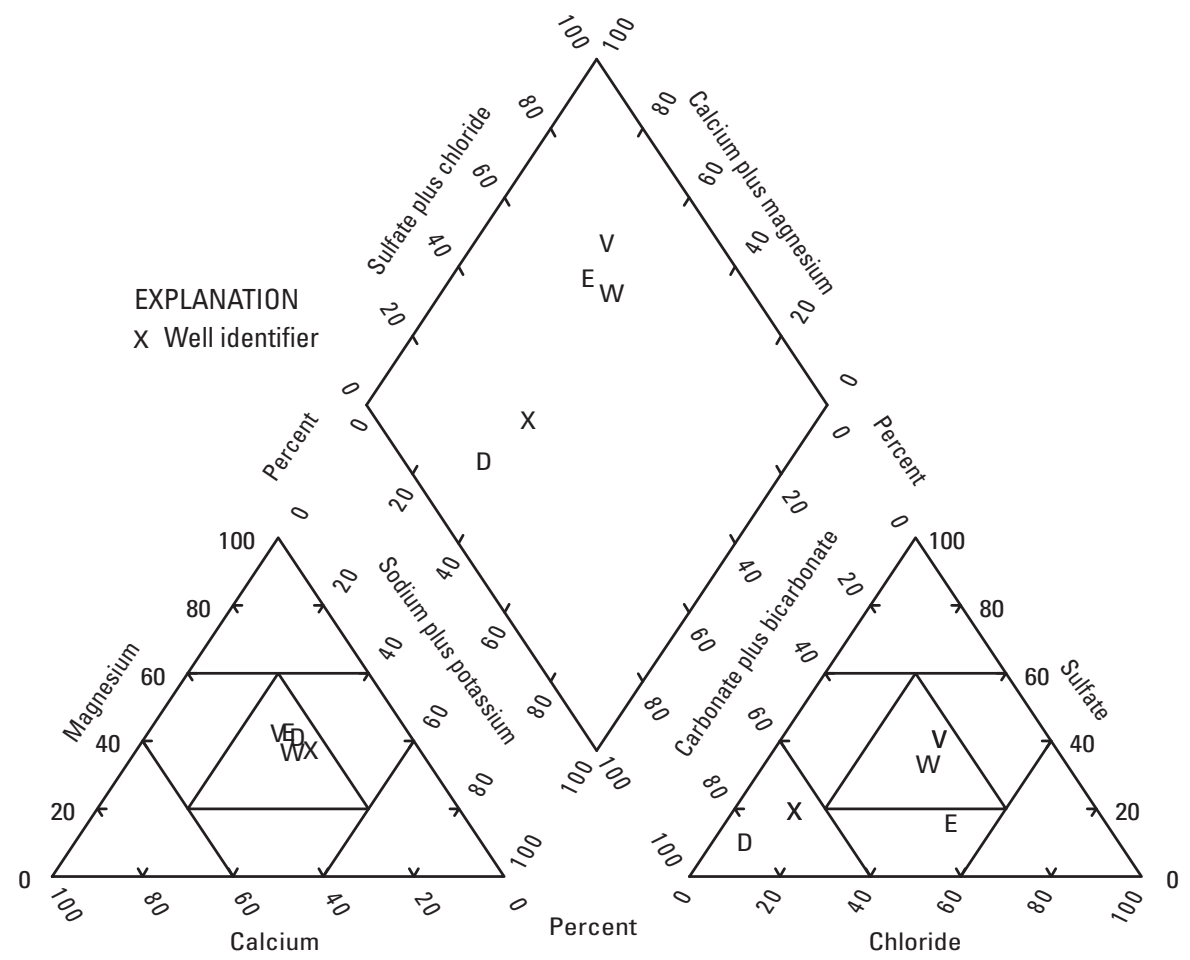

Figure 14. Piper diagram of major-ion composition in ground water from selected wells at Cannon Air Force Base, July 2004.

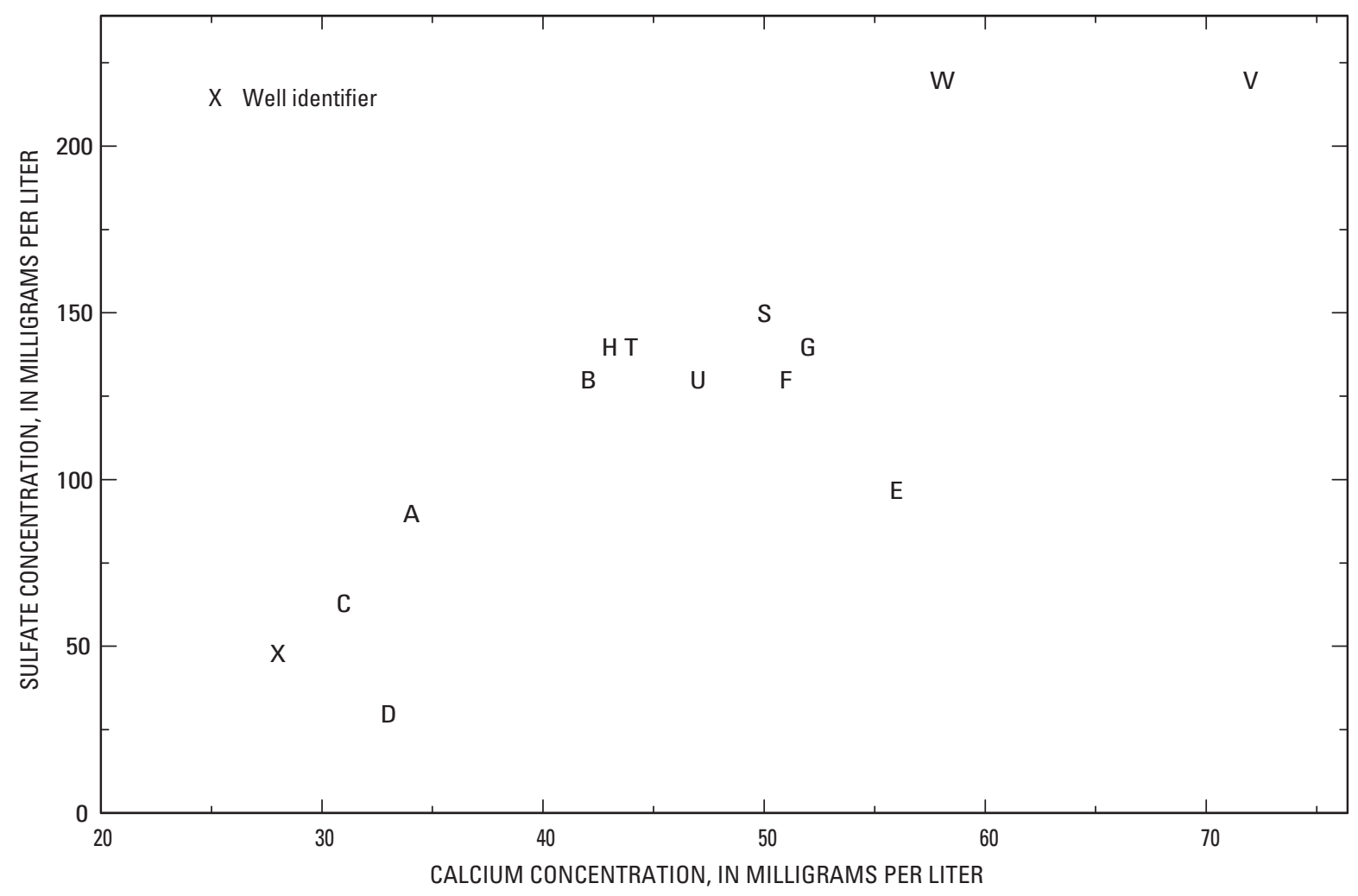

Figure 15. Calcium and sulfate concentrations in ground water at Cannon Air Force Base, June 2004. 


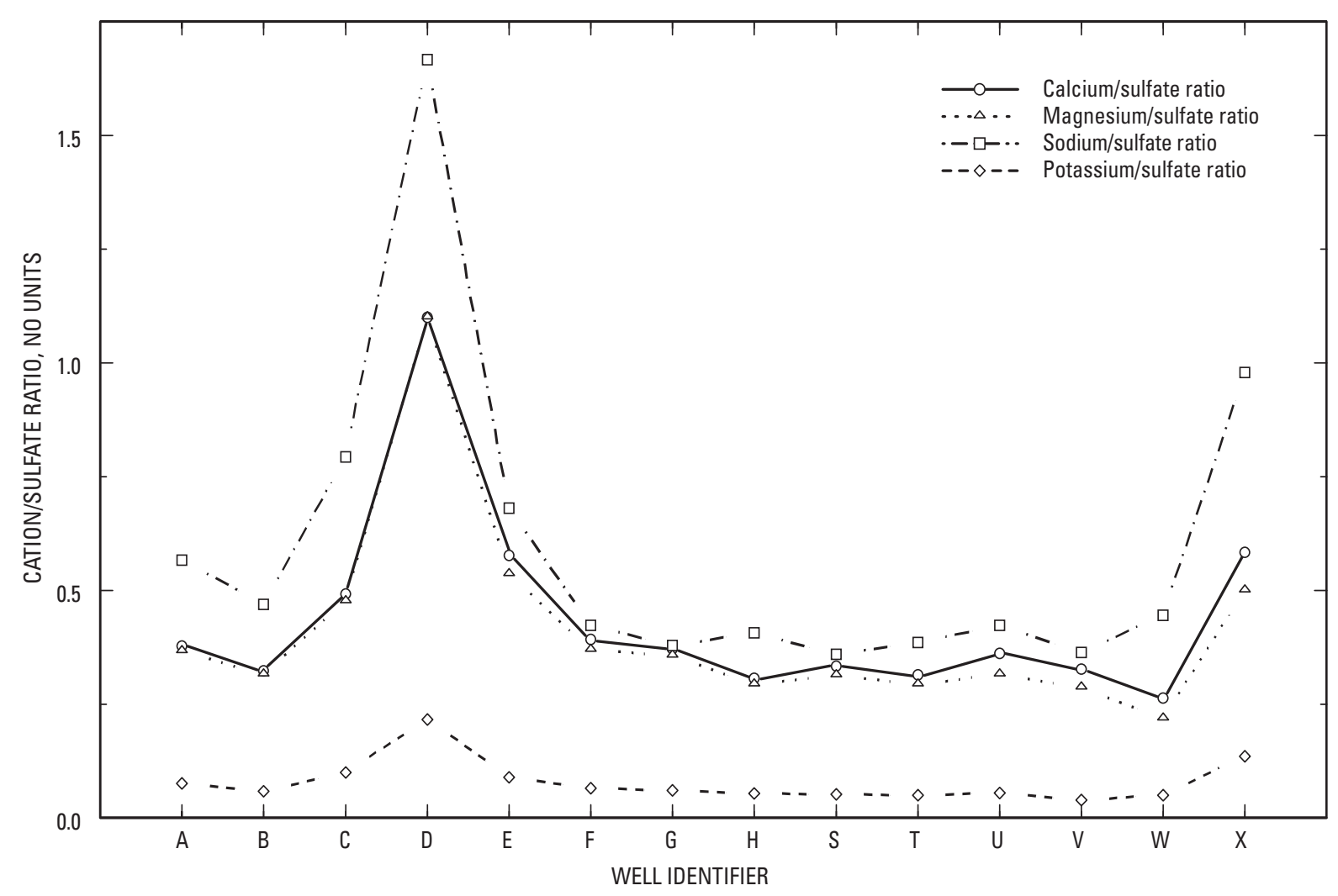

Figure 16. Cation and sulfate ratios for ground water at Cannon Air Force Base, June 2004.

ion ratios can suggest different rock/water interactions for the possible source waters.

Because the influence of Sewage Lagoons appears to have lessened by 2004 (fig. 12) and the largest concentrations of calcium and sulfate in 2004 were detected in wells upgradient from the Sewage Lagoons (background wells V and W), the Southern High Plains aquifer at Cannon AFB likely is a mixture of multiple source waters. Ground water of different ages and composition was evident from USGS sampling at Melrose Air Force Range for the Southern High Plains aquifer (Langman and others, 2004). Age dating of ground water at Cannon AFB by the USGS (Falk, 2005) produced a range of ages ( 25 to 50 years) and indicated mixing of source waters. It is possible that source waters from different formations or recharge areas are mixing in the Cannon AFB area, but the water-quality data set from USGS monitoring at Landfill 5 and the Sewage Lagoons is insufficient to support this conclusion.

\section{General Physical and Chemical Properties}

The general physical and chemical properties (specific conductance, temperature, and $\mathrm{pH}$ ) of ground water at Cannon AFB provide an overview of spatial and temporal differences in water quality. Specific conductance is a particularly useful parameter because it indicates the amount of dissolved ions in the water. The large range and large values of specific conductance in water from wells E, F, G, and P (fig. 17) likely were a result of infiltrating water from the Sewage Lagoons (fig. 2). Although well E is upgradient from the Sewage Lagoons, infiltrating water from the lagoons likely spread in all directions in the approximately 300 -ft-thick vadose zone and affected water quality in an area surrounding the lagoons. Human use of water typically increases the mineral content, which results in treated wastewater with larger specific conductance than the source water (Tchobanoglous, 1991). Additionally, evaporation of treated wastewater in the lagoons would further increase specific conductance of water that would infiltrate and mix with the underlying aquifer.

The specific conductance of ground water in wells outside the influence of the Sewage Lagoons (wells I, L, M, Q, S, $\mathrm{T}, \mathrm{U}, \mathrm{V}, \mathrm{W}$, and $\mathrm{X}$ ) also indicated differences in water quality and may indicate the mixing of source waters in the Southern High Plains aquifer at Cannon AFB (fig. 17). This spatial difference in specific conductance in the Southern High Plains aquifer was observed at Melrose Air Force Range (25 mi west of Cannon AFB) (fig. 1) and was attributed to upward flow of larger conductance water from the Chinle Formation into the Ogallala Formation (Langman and others, 2004). Identifying cross-formational flow at Cannon AFB is complicated by possible anthropogenic influences and (or) multiple recharge source waters and cannot be determined from the Landfill 5 and Sewage Lagoons data sets. 


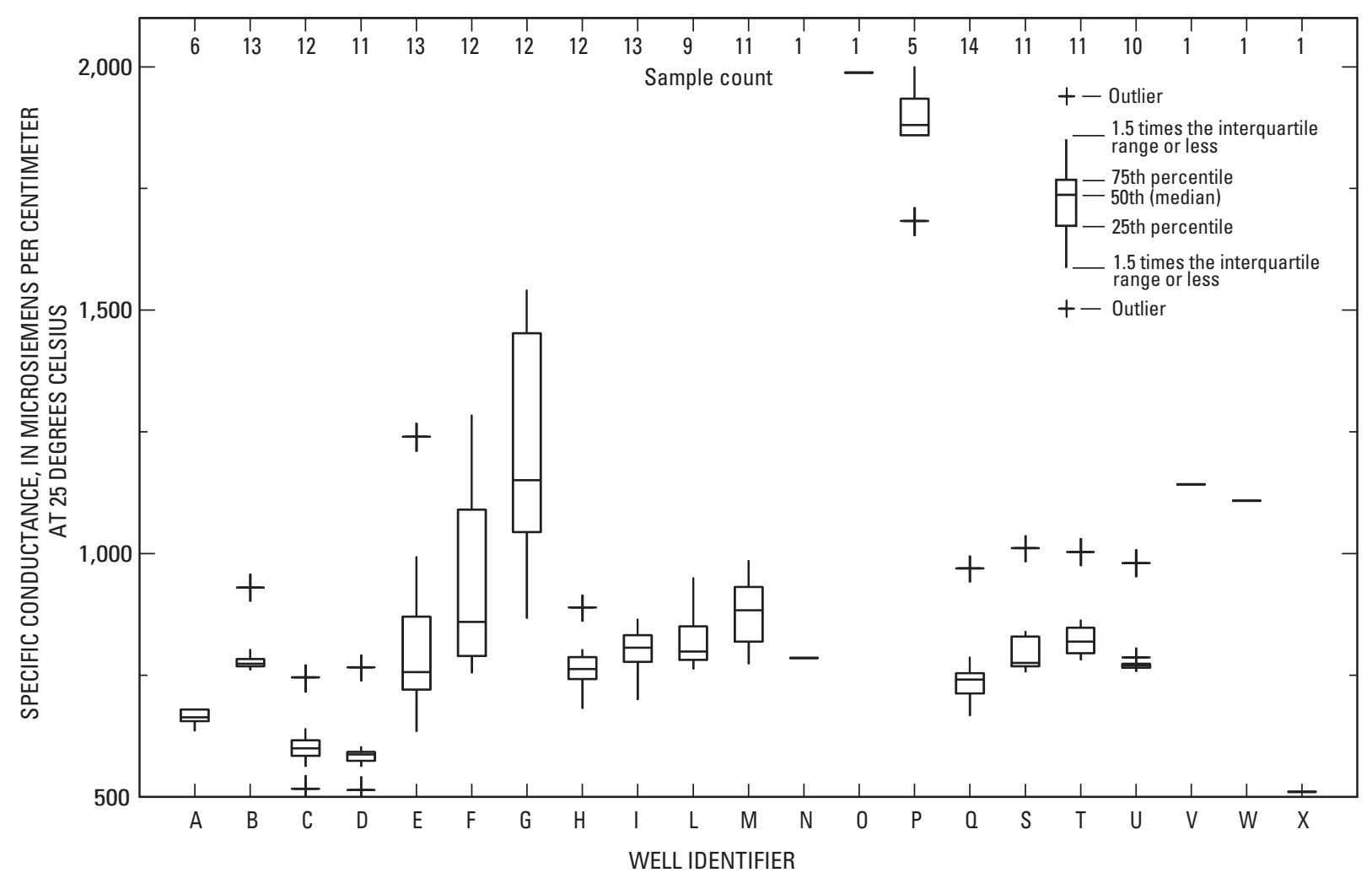

Figure 17. Ground-water specific conductance at Cannon Air Force Base, 1994-2004.

The specific conductance in water from the wells near the Sewage Lagoons decreased from 1994 to 1998 because of the declining influence of infiltrating wastewater as the lagoons were decommissioned and finally closed in 1998 (fig. 18). Infiltrating wastewater from the lagoons appears to have substantially influenced the water quality in wells closest to the lagoons and in the direction of ground-water flow (northwest to southeast). Two years after the final closure of the lagoons, specific conductance in ground water from wells $\mathrm{E}$, $\mathrm{F}$, and $\mathrm{H}$ steadily began to increase. The source of this increase is unknown but may be related to the possibility of multiple source waters for the aquifer at Cannon AFB.

Ground water in wells near Landfill 5 indicates possible multiple source waters or anthropogenic influences (fig. 19). Specific conductance of ground water in wells along the southern boundary of the landfill (wells C and D) were smaller than values for ground water in wells along the eastern boundary (B, S, T, and U). Landfill 5 does not appear to be the source or only source causing this difference because the specific conductance of ground water in well A (background well for Landfill 5 sampling) was typically larger than values for wells $\mathrm{C}$ and $\mathrm{D}$, although values for well A were typically smaller than values for wells B, S, T, and U (fig. 17). The increasing specific conductance in ground water near the Sewage Lagoons after decommissioning of the lagoons is not apparent with ground water near Landfill 5.
The majority of recorded ground-water temperatures at Cannon AFB were between 16 and $20^{\circ} \mathrm{C}$ (fig. 20). The largest ground-water temperatures were at wells I, L, and M, located in the southeastern corner of the base near Landfill 5. These wells were completed at shallower depths compared to most of the remaining wells (table 1), and these wells no longer contain water because of declining water levels. Ground water in these wells indicated seasonal fluctuations in temperature, which could be attributed to seasonal recharge.

Ground-water $\mathrm{pH}$ at Cannon AFB was slightly alkaline; most values were larger than 7.0, and all median $\mathrm{pH}$ values were between 7.0 and 8.0 (fig. 21). The smallest median $\mathrm{pH}$ value was for ground water at well $\mathrm{M}$, and the largest median value was for ground water at well U. Ground water from wells near Landfill 5 indicated the largest variations in $\mathrm{pH}$.

\section{Summary}

In cooperation with the U.S. Air Force, the U.S. Geological Survey has collected hydrologic data about the Southern High Plains aquifer at Cannon Air Force Base in east-central New Mexico since 1994. This report summarizes and interprets available hydrologic data collected by the USGS at Cannon AFB from 1994 to 2005. Under the direction of Cannon AFB, the USGS collected hydrologic data at regulated sites of 


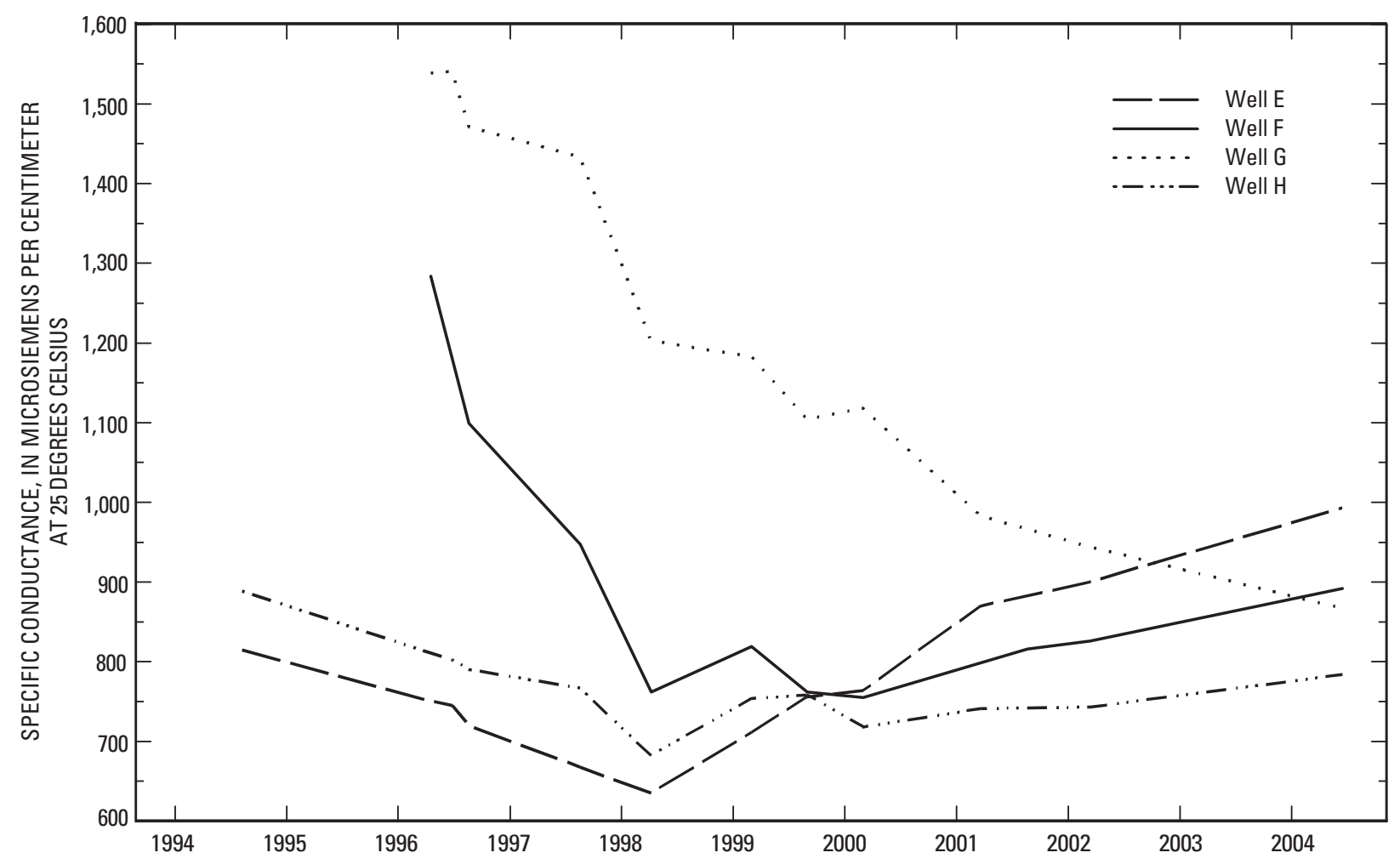

Figure 18. Ground-water specific conductance near the Sewage Lagoons at Cannon Air Force Base, 1994-2004.

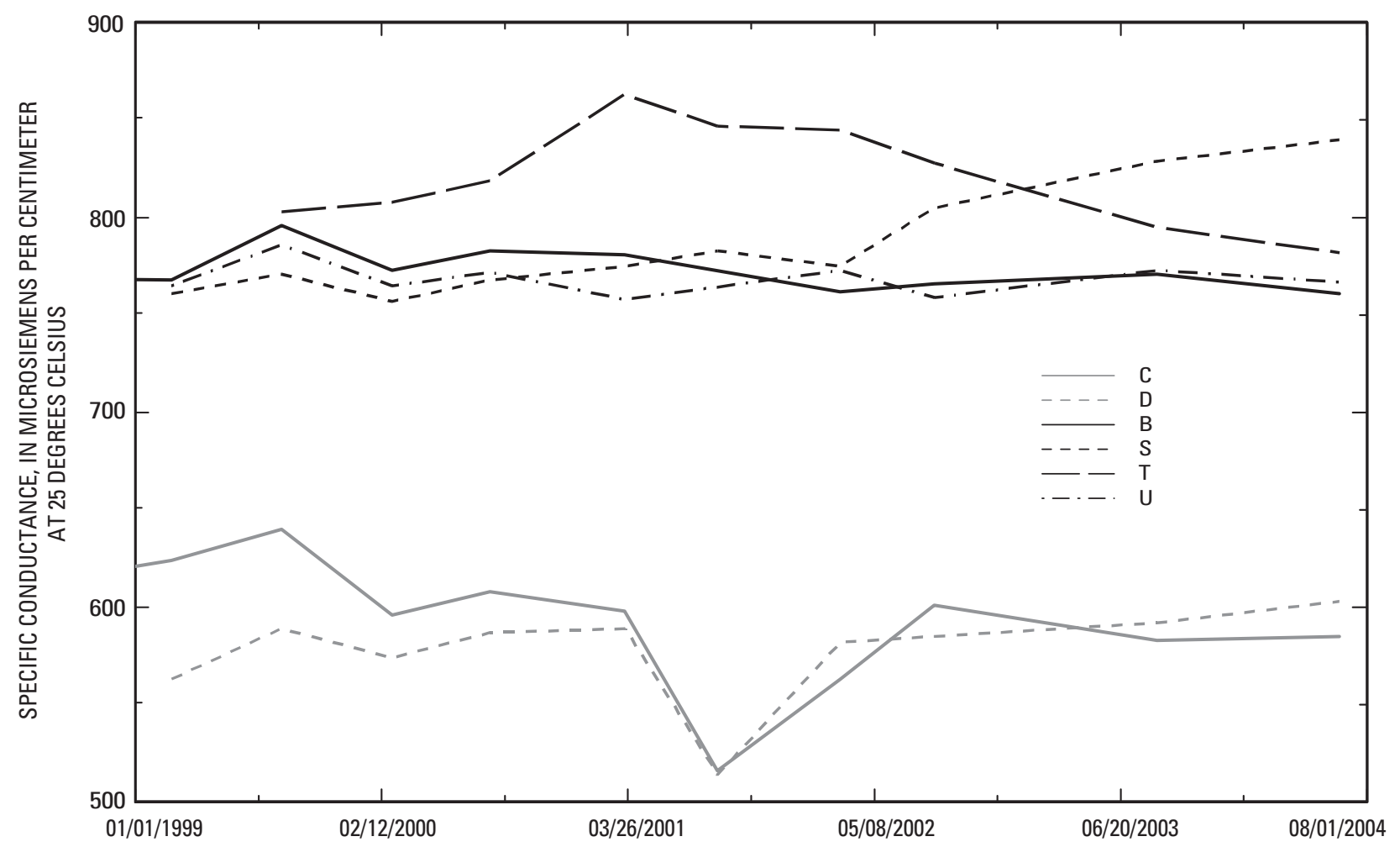

Figure 19. Ground-water specific conductance near Landfill 5 at Cannon Air Force Base, 1999-2004. 


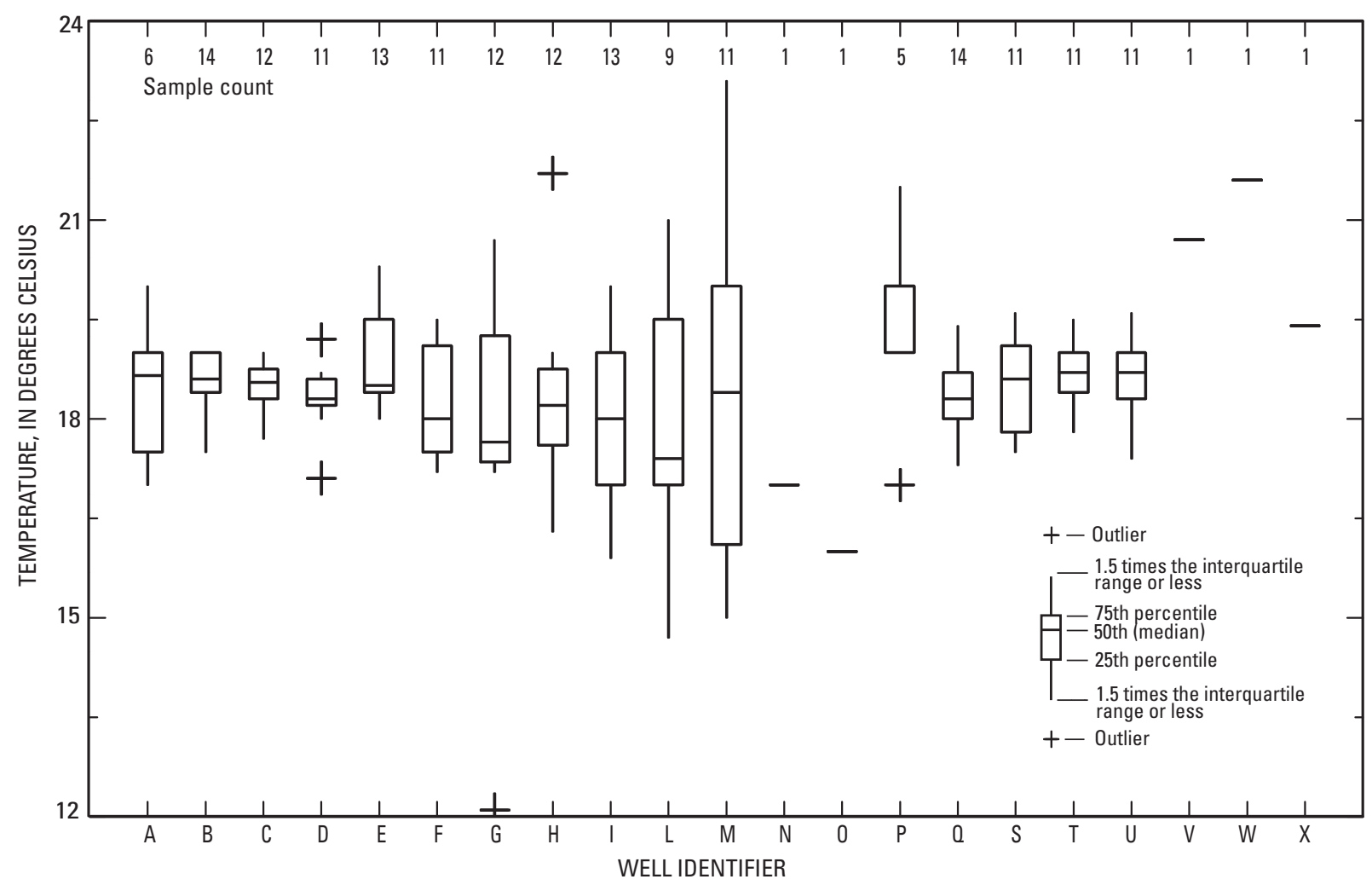

Figure 20. Ground-water temperatures at Cannon Air Force Base, 1994-2004.

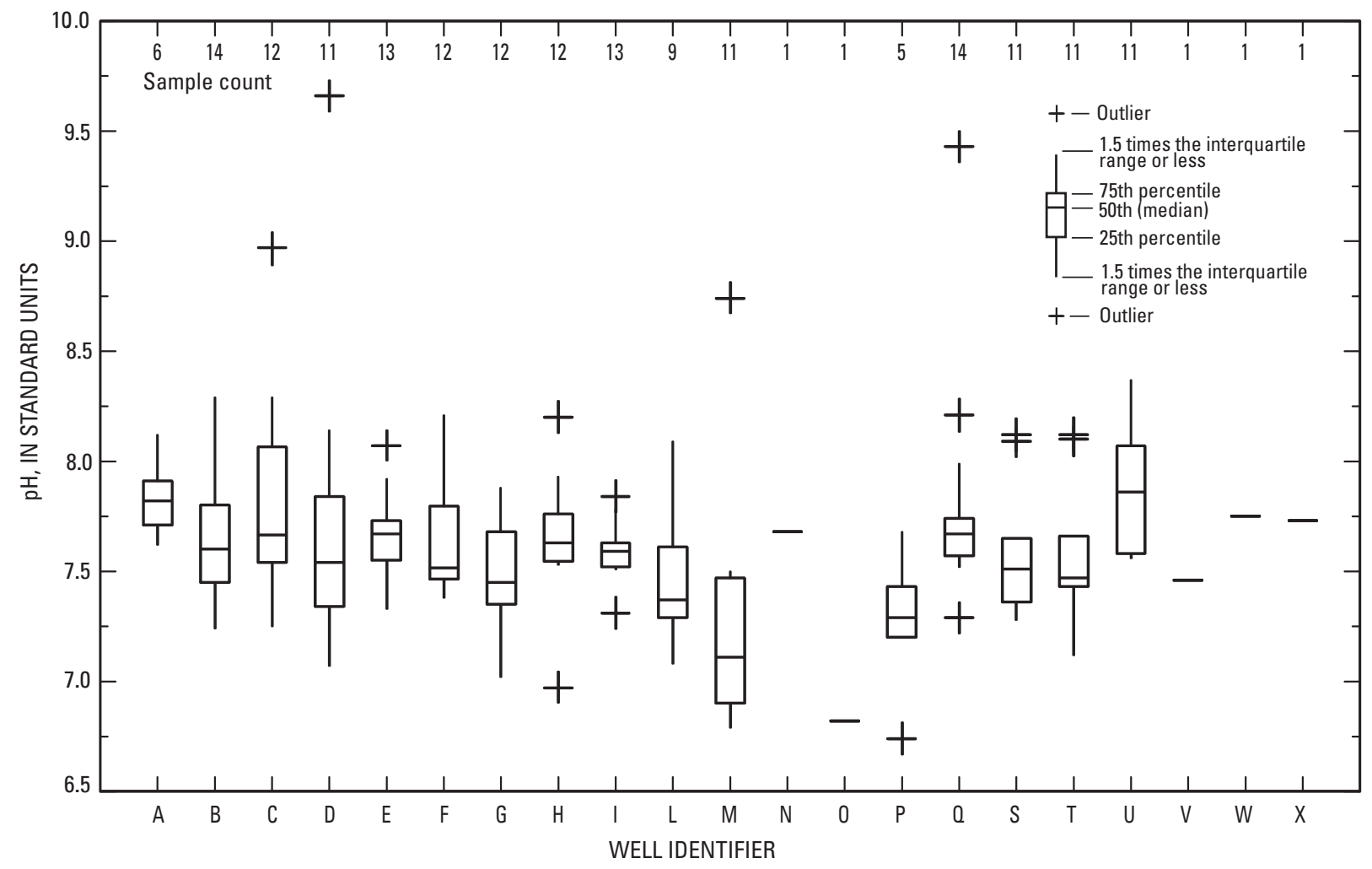

Figure 21. Ground-water pH at Cannon Air Force Base, 1994-2004. 
Landfill 5 and the Sewage Lagoons as required by the State of New Mexico. The interpretation of data collected at these sites provides a characterization of the Southern High Plains aquifer that Cannon AFB environmental managers can use for future planning efforts to protect the aquifer and ensure continued operation of all current (2006) activities. Data were compiled from all monitoring wells used from 1994 to 2005 for compliance with RCRA regulations applicable to the Landfill 5 site and the NPDES regulations applicable to the Sewage Lagoons site. Ground-water altitude data also were compiled from an additional 120 wells in a 3-mi radius of Cannon AFB to examine the hydrologic properties of the aquifer at Cannon AFB in relation to the regional aquifer properties.

Cannon AFB is located in the Southern High Plains physiographic region, and saturated deposits of the Ogallala Formation at Cannon AFB are within the western boundary of the Southern High Plains aquifer. The general direction of ground-water flow in the Cannon AFB area is from northwest to southeast. In 1962, ground water in the Southern High Plains aquifer predominantly flowed northwest to southeast with minimal change in direction. Ground-water altitudes declined from 1962 to 1997, and a pronounced water-level recession (area of receding water level) developed northwest of Cannon AFB, altering flow direction in this area. The recession northwest of the base and the subsequent change in direction of ground-water flow are indicative of local ground-water withdrawals upgradient from Cannon AFB.

Ground-water levels have declined substantially throughout the Southern High Plains aquifer since the mid-1940s when ground water was first used for irrigated agriculture. Historical water levels in wells within a 3-mi radius of Cannon AFB declined in 52 of 56 wells for various periods of record between 1962 and 2004, 43 of 56 wells indicated strong linear decreases with time, and the largest decline was $91.80 \mathrm{ft}$, an average annual decline of about $2.13 \mathrm{ft}$ per year. Water levels in wells at Cannon AFB reflected the regional decline; water levels declined for all wells with periods of record greater than 1 year, and the decline was strongly linear. Wells with the longest records of water-level measurements exhibited minor periods of recovery but a dominant decline in water levels during the past 50 years. These declining regional water-level data likely indicate ground-water withdrawals from the resource that exceeded recharge.

From 1994 to 2005, rates of declining water levels at the base ranged from 1.45 to $1.64 \mathrm{ft}$ per year near the Sewage Lagoons and from 2.24 to $4.01 \mathrm{ft}$ per year near Landfill 5. The difference in rates of decline for ground water at the Sewage Lagoons and Landfill 5 was likely a result of local recharge to the aquifer near the Sewage Lagoons from infiltration of treated wastewater from the previously used lagoons and the current disposal area (Playa Lake). The largest variation in water levels at Cannon AFB was observed in wells C, D, and $\mathrm{S}$, which are located near Landfill 5 along the southern boundary of the base and near an irrigation well immediately south of the base boundary. Water levels in C, D, and S indicated a pattern of summer water-level decline followed by partial winter water-level recovery, which was likely a result of drawdown and recovery during the irrigation and nonirrigation seasons. This water-level pattern, however, was scarcely apparent or was absent in wells A and Q, which are about $0.4 \mathrm{mi}$ north-northwest of the irrigation well.

Ground-water sampling by the USGS from 1994 to 2004 at monitoring wells associated with Landfill 5 and the Sewage Lagoons indicated temporal and spatial differences in water quality. At least one anthropogenic compound was detected in ground water from each monitoring well surrounding Landfill 5 and the Sewage Lagoons. All compounds detected were either pesticide or industrial compounds, and all concentrations were less than USEPA drinking-water standards. Perchlorate was detected in at least one sample from every well for which perchlorate was analyzed, but the source of perchlorate is likely natural and probably a result of atmospheric deposition. Trace-element concentrations in raw ground water at Cannon AFB were generally less than USEPA drinkingwater standards. Maximum concentrations of aluminum, iron, and manganese exceeded secondary drinking-water standards, and maximum chromium concentrations exceeded the primary drinking-water standard. Results of nitrate plus nitrite analysis indicate that only samples from wells $\mathrm{G}$ and $\mathrm{P}$ exceeded the drinking-water standard of $10 \mathrm{mg} / \mathrm{L}$.

Larger concentrations of nitrate in ground water at wells $\mathrm{G}$ and $\mathrm{P}$ were likely a result of infiltrated treated wastewater. From 1994 to 2004, during which the Sewage Lagoons were decommissioned, nitrate concentrations in wells near the Sewage Lagoons decreased to levels found in wells not affected by infiltrating wastewater. Concentrations of TOC were generally near or less than $1 \mathrm{mg} / \mathrm{L}$ in ground water at the base. One detection of TOC in ground water at well F in 2004 was at a concentration of $9.5 \mathrm{mg} / \mathrm{L}$. Ground water from well $\mathrm{F}$ previously did not contain a detectable concentration of TOC. The reason for such a large increase in TOC concentration in ground water from well $\mathrm{F}$ is unknown.

The spatial and temporal variation of major ions and specific conductance of ground water at Cannon AFB indicates various natural and (or) anthropogenic influences on ground water. Calcium and sulfate concentrations were widely variable in ground-water samples collected in 2004 from wells across the base. Similar cation/sulfate ratios were present for samples from nearly all wells, except for samples from certain wells along the southern boundary of the base and the background well for the Sewage Lagoon monitoring. Differences in major-ion concentrations and ratios and specific conductance across the base were likely the result of different source waters that form the Southern High Plains aquifer.

The decreasing specific conductance from 1994 to 1998 in water from wells near the Sewage Lagoons is explained by the decreasing influence of infiltrating wastewater as the lagoons were decommissioned. Infiltrating wastewater from 
the lagoons appears to have substantially influenced the water quality in wells closest to the lagoons and in the direction of ground-water flow (northwest to southeast). Two years after the decommissioning of the lagoons, specific conductance in ground water from wells $\mathrm{E}, \mathrm{F}$, and $\mathrm{H}$ began to increase steadily. The source of this increase is unknown but may be related to the possibility of multiple source waters for the Southern High Plains aquifer at Cannon AFB. The increasing specific conductance in ground water near the Sewage Lagoons after decommissioning of the lagoons was not apparent with ground water near Landfill 5.

\section{References Cited}

Back, William, 1961, Techniques for mapping of hydrochemical facies: U.S. Geological Survey Professional Paper 424-D, p. 380-382.

Bhate Environmental Associates, Inc., 2002a, Annual monitoring report, December 2001, ERP site nos. LF-03 (MW-O), LF-04 (MW-N), and LF-25 (MW-Ra), Cannon Air Force Base, Clovis, New Mexico: Prepared for Cannon Air Force Base, Air Combat Command, Clovis, New Mexico, variously paged.

Bhate Environmental Associates, Inc., 2002b, Final, Semiannual monitoring report, July 2001, ERP site no. LF-25 (MW-Ra), Cannon Air Force Base, Clovis, New Mexico: Prepared for Cannon Air Force Base, Air Combat Command, Clovis, New Mexico, variously paged.

Bhate Environmental Associates, Inc., 2003a, Final, Annual monitoring report, December 2002, ERP site nos. LF03, LF-04, LF-25, Cannon Air Force Base, Clovis, New Mexico: Prepared for Cannon Air Force Base, Air Combat Command, Clovis, New Mexico, variously paged.

Bhate Environmental Associates, Inc., 2003b, Final, Semiannual monitoring report, June 2002, ERP site no. LF-25, Cannon Air Force Base, Clovis, New Mexico: Prepared for Cannon Air Force Base, Air Combat Command, Clovis, New Mexico, variously paged.

Bhate Environmental Associates, Inc., 2004, Final, Semiannual monitoring report, June 2003, Landfill no. LF-25 (MW-Ra), Cannon Air Force Base, Clovis, New Mexico: Prepared for Cannon Air Force Base, Air Combat Command, Clovis, New Mexico, variously paged.

Bhate Environmental Associates, Inc., 2005, Final, Annual monitoring report, December 2003, Landfill nos. LF-25 (MW-Ra), LF-03 (MW-O), and LF-04 (MW-N), Cannon Air Force Base, Clovis, New Mexico: Prepared for Cannon Air Force Base, Air Combat Command, Clovis, New Mexico, variously paged.
Cannon Air Force Base, 2002, Management action plan, Air Combat Command, Cannon Air Force Base, New Mexico, December 2002: Air Force project no. ACCH20027544, 266 p.

Council on Water Quality, 2005, Regulation of perchlorate: Web site accessed March 30, 2005, at URL http://www. councilonwaterquality.org/issue/regulation.html.

Dasgupta, P.K., Martinelango, P.K., Jackson, W.A., Anderson, T.A., Tian, K., Tock, R.W., and Rajagopalan, S., 2005, The origin of naturally occurring perchlorate-The role of atmospheric processes: Environmental Science and Technology, v. 39, no. 6, 1569-1575.

Dick-Peddie, W., 1993, New Mexico vegetation-Past, present, and future: Albuquerque, University of New Mexico Press, 244 p.

Dutton, A.R., Mace, R.E., and Reedy, R.C., 2001, Quantification of spatially varying hydrogeologic properties for a predictive model of groundwater flow in the Ogallala aquifer, northern Texas panhandle, in Lucas, S.G., and UlmerScholle, D.S., eds., Geology of Llano Estacado: Socorro, New Mexico Geological Society, p. 297-307.

Dutton, A.R., and Simpkins, W.W., 1986, Hydrogeochemistry and water resources of the Triassic Lower Dockum Group in the Texas Panhandle and eastern New Mexico: Report of Investigations no. 161, Bureau of Economic Geology, University of Texas at Austin, $51 \mathrm{p}$.

Earth Tech, Inc., 2005, Draft wellhead protection plan, Cannon Air Force Base, Curry County, New Mexico: variously paged.

Fahlquist, L.S., 2003, Ground-water quality of the Southern High Plains aquifer, Texas and New Mexico, 2001: U.S. Geological Survey Open-File Report 2003-345, 59 p.

Falk, S.E., 2005, Estimated ground-water age and rates of recharge in the Southern High Plains aquifer, Cannon Air Force Base, Curry County, New Mexico, 2005: Master's thesis, Albuquerque, University of New Mexico, Civil Engineering Department, Albuquerque, variously paged.

Fenneman, N.M., and Johnson, D.W., 1946, Physical divisions of the United States: U.S. Geological Survey, scale $1: 7,000,000$.

Gustavson, T.C., 1996, Fluvial and eolian depositional systems, paleosols, and paleoclimate of the upper Cenozoic Ogallala and Blackwater Draw Formations, Southern High Plains, Texas and New Mexico: Report of Investigations No. 239, Bureau of Economic Geology, University of Texas at Austin, 62 p. 
Hart, D.L., and McAda, D.P., 1985, Geohydrology of the High Plains aquifer in southeastern New Mexico: U.S. Geological Survey Hydrologic Investigations Atlas HA-679.

Jackson, W.A., Rainwater, K., Anderson, T., Lehman, T., Tock, R., Mollhagen, T., and Ridley, M., 2003, Distribution and potential sources of perchlorate in the High Plains region of Texas: Final Report Phase 1, Lubbock, Texas Tech University Water Resources Center, 80 p.

Langman, J.B., Gebhardt, F.E., and Falk, S.E., 2004, Groundwater hydrology and water quality of the Southern High Plains aquifer, Melrose Air Force Range, Cannon Air Force Base, Curry and Roosevelt Counties, New Mexico, 200203: U.S. Geological Survey Scientific Investigations Report 2004-5158, $42 \mathrm{p}$.

Mantei, C.L., Ribbens, R.W., and Phillips, H.B., 1966-1967, Electric analog studies of ground water conditions in Portales Valley, Portales Project, New Mexico: U.S. Bureau of Reclamation, Division of Design, progress reports, variously paged.

McGowen, J.H., Granata, G.E., and Seni, S.J., 1977, Depositional systems, uranium occurrence, and postulated ground-water history of the Triassic Dockum Group, Texas Panhandle-Eastern New Mexico: Bureau of Economic Geology, University of Texas at Austin, 104 p.

McGuire, V.L., Johnson, M.R., Schieffer, R.L., Stanton, J.S., Sebree, S.K., and Verstraeten, I.M., 2003, Water in storage and approaches to ground-water management, High Plains aquifer, 2000: U.S. Geological Survey Circular 1243, 51 p.

McLemore, V.T., 2001, Oasis State Park, in Lucas, S.G., and Ulmer-Scholle, D.S., eds., Geology of Llano Estacado: Socorro, New Mexico Geological Society, p. 34-37.

Musharrafieh, G.R., and Logan, L.M., 1999, Numerical simulation of groundwater flow for water rights administration in the Curry and Portales Valley underground water basins, New Mexico: Santa Fe, New Mexico Office of the State Engineer, Technical Division Hydrology Bureau Report 99-2, 169 p.

MWH, 2004, Cannon Air Force Base, draft customer concept document, hydraulic and water quality monitoring project, water distribution system repairs and upgrades, July 2004: Prepared for Cannon Air Force Base, Air Combat Command, Clovis, New Mexico, variously paged.

Nativ, Ronit, 1988, Hydrogeology and hydrochemistry of the Ogallala aquifer, Southern High Plains, Texas Panhandle and eastern New Mexico: Report of Investigations no. 177, Bureau of Economic Geology, University of Texas at Austin, 64 p.
Nativ, Ronit, and Gutierrez, G.N., 1988, Hydrogeology and hydrochemistry of Cretaceous aquifers, Texas Panhandle and eastern New Mexico: Geological Circular 88-3, Bureau of Economic Geology, University of Texas at Austin, 32 p.

New Mexico Office of the State Engineer, 2005, Water basins and other miscellaneous maps, New Mexico Office of the State Engineer, Santa Fe: accessed May 30, 2005, at URL http://www.ose.state.nm.us/PDF/Maps/underground_water.pdf.

Oblinger Childress, C.J., Foreman, W.T., Connor, B.F., and Maloney, T.J., 1999, New reporting procedures based on long-term method detection levels and some considerations for interpretations of water-quality data provided by the U.S. Geological Survey National Water Quality Laboratory: U.S. Geological Survey Open-File Report 99-193, 19 p.

Parallax, Inc., 2000, Semi-annual monitoring report, August 2000 sampling event, long-term monitoring, Landfill no. 25 (MW-R), Cannon Air Force Base, Clovis, New Mexico: prepared for Cannon Air Force Base, variously paged.

Plummer, L.N., and Busenberg, E., 2000, Chlorofluorocarbons, in Cook, P., and Herczeg, A.L., eds., Environmental tracers in subsurface hydrology: Chap. 15, Norwell, Mass., Kluwer Academic Publishers, p. 441-478.

Plummer, L.N., Bohlke, J.K., and Doughten, M.W., 2006, Perchlorate in Pleistocene and Holocene groundwater in north-central New Mexico: Environmental Science and Technology, v. 40, no. 6, p. 1757-1763.

Rajagopalan, S., Anderson, T.A., Fahlquist, L., Rainwater, K.A., Ridley, M., and Jackson, W.A., 2006, Widespread presence of naturally occurring perchlorate in High Plains of Texas and New Mexico: Environmental Science and Technology, v. 40, no. 10, p. 3156-3162.

Scanlon, B.R., Angle, E.S., Christian, B., Pi, J., Martinez, K., Reedy, R., Boghici, R., and Petrossian, R., 2003, Evaluation of enhanced recharge potential to the Ogallala aquifer in the Brazos River Basin, Hale County, Texas: Texas Water Development Board Report 355, 66 p.

Severn Trent Laboratories, Inc., 2004, Analytical report, Cannon Air Force Base, STL Denver, July 2004, variously paged.

Stone, W.J., and McGurk, B.E., 1985, Ground-water recharge on the Southern High Plains, east-central New Mexico, in Lucas, S.G., and Zidek, J., eds., Guidebook of Santa RosaTucumcari region, 36th Field Conference: Socorro, New Mexico Geological Society, p. 331-335.

Tchobanoglous, George, 1991, Wastewater engineering-Treatment, disposal, and reuse: New York, Metcalf \& Eddy, Inc., 3d edition (rev. by Tchobanoglous, G., and Burton, F.), 1334 p. 
Tetra Tech EC, Inc., 2005, Construction completion report for SWMU 101-Sewage lagoons: Cannon Air Force Base, New Mexico, variously paged.

Trauger, F.D., 1972, Ground water in east-central New Mexico, in Kelly, V.C., and Trauger, F.D., eds., Guidebook of east-central New Mexico: Socorro, New Mexico Geological Society, p. 201-207.

Tuan, Y.F., Everard, C.E., and Widdison, J.G., 1969, The climate of New Mexico: Santa Fe, New Mexico State Planning Office, 169 p.

U.S. Environmental Protection Agency, 1983, Method for chemical analysis of water and wastes: EPA-600/4-79-020, March 1983 and subsequent revisions.

U.S. Environmental Protection Agency, 1986, Test methods for evaluating solid waste, physical/chemical methods: $3 \mathrm{~d}$ edition, November 1986 and subsequent updates.

U.S. Environmental Protection Agency, 1999, Methods for the determination of organic and inorganic compounds in drinking water: EPA/815-R-00-014, v. 1, revision 1, 49 p.

U.S. Environmental Protection Agency, 2005a, EPA sets reference dose for perchlorate, release date 02/18/2005: accessed May 30, 2006, at URL http://yosemite.epa.gov/ opa/admpress.nsf/blab9f485b098972852562e7004dc686/ cla57d2077c4bfda85256fac005b8b32.
U.S. Environmental Protection Agency, 2005b, List of drinking water contaminants \& MCLs, Office of Ground Water and Drinking Water: accessed March 30, 2005, at URL http://www.epa.gov/safewater/mcl.html.

U.S. Geological Survey, 2002, National Geologic Map (GEOLEX) database, geologic unit name-Chinle, U.S. Geological Survey, Reston, Va.: accessed September 10, 2003, at URL http://ngmdb.usgs.gov/Geolex/geolex_qs.html.

Western Regional Climate Center, 2005a, New Mexico climate summaries for cooperator stations, Clovis, New Mexico, station 291939, period of record monthly climate summary, period of record: 11/24/1910 to 12/31/2004: accessed May 18, 2005, at URL http://www.wrcc.dri.edu/cgi-bin/cliMAIN. pl?nmclov.

Western Regional Climate Center, 2005b, Monthly average pan evaporation: accessed May 18, 2005, at URL http:// www.wrcc.dri.edu/htmlfiles/westevap.final.html.

Wilde, F.D., and Radtke, D.B., August 2005, Field measurements: U.S. Geological Survey Techniques of WaterResources Investigations, book 9, chap. A6, section 6.0, accessed May 15, 2006, at URL http://pubs.water.usgs. gov/twri9A6/. 


\section{Supplemental Information}

Figure I-1. Location of selected wells at Cannon Air Force Base and the surrounding area.

Table I-1. Information for selected wells at Cannon Air Force Base and the surrounding area.

Table I-2. Altitudes of water levels in selected wells at Cannon Air Force Base and the surrounding area. 


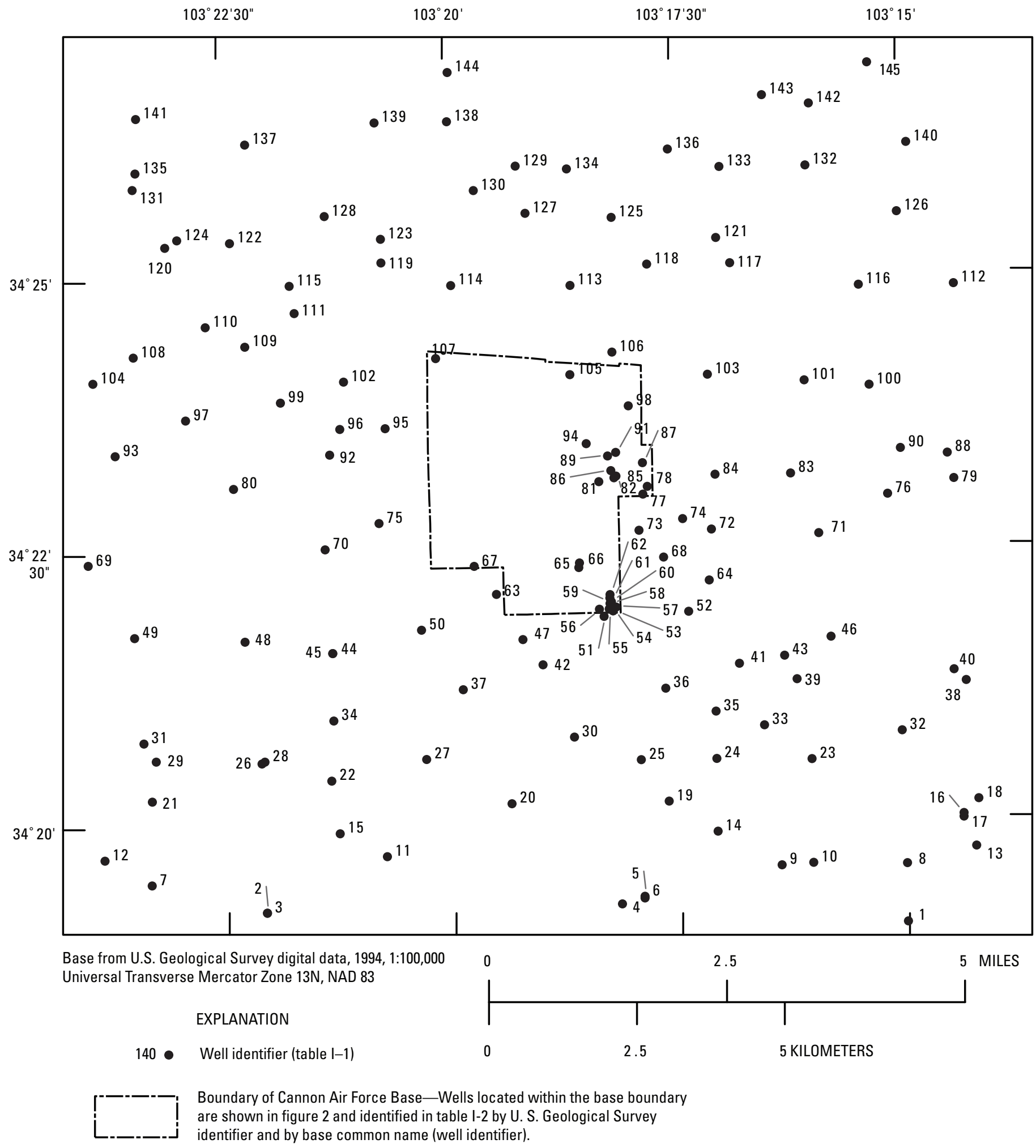

Figure I-1. Location of selected wells at Cannon Air Force Base and the surrounding area. 
Table I-1. Information for selected wells at Cannon Air Force Base and the surrounding area.

[NAD 83, North American Datum of 1983; NAVD 88, North American Vertical Datum of 1988; ft, feet; bls, below land surface; --, not available]

\begin{tabular}{|c|c|c|c|c|c|}
\hline $\begin{array}{l}\text { Map identifier } \\
\text { (fig. I-1) }\end{array}$ & $\begin{array}{l}\text { U.S. Geological Survey } \\
\text { identification number }\end{array}$ & Latitude (NAD 83) & Longitude (NAD 83) & $\begin{array}{l}\text { Land-surface } \\
\text { altitude (ft above } \\
\text { NAVD 88) }\end{array}$ & Well depth (ft bls) \\
\hline 1 & 341903103145601 & $34^{\circ} 19^{\prime} 03^{\prime \prime}$ & $103^{\circ} 14^{\prime} 58^{\prime \prime}$ & 4,196 & 342 \\
\hline 2 & 341913103220001 & $34^{\circ} 19^{\prime} 13^{\prime \prime}$ & $103^{\circ} 22^{\prime} 02^{\prime \prime}$ & 4,180 & -- \\
\hline 3 & 341913103220002 & $34^{\circ} 19^{\prime} 13^{\prime \prime}$ & $103^{\circ} 22^{\prime} 02^{\prime \prime}$ & 4,180 & -- \\
\hline 4 & 341915103180501 & $34^{\circ} 19^{\prime} 15^{\prime \prime}$ & $103^{\circ} 18^{\prime} 07^{\prime \prime}$ & 4,197 & -- \\
\hline 5 & 341918103175001 & $34^{\circ} 19^{\prime} 18^{\prime \prime}$ & $103^{\circ} 17^{\prime} 52^{\prime \prime}$ & 4,213 & -- \\
\hline 6 & 341919103175001 & $34^{\circ} 19^{\prime} 19^{\prime \prime}$ & $103^{\circ} 17^{\prime} 52^{\prime \prime}$ & 4,213 & -- \\
\hline 7 & 341929103231601 & $34^{\circ} 19^{\prime} 29^{\prime \prime}$ & $103^{\circ} 23^{\prime} 18^{\prime \prime}$ & 4,176 & -- \\
\hline 8 & 341935103145601 & $34^{\circ} 19^{\prime} 35^{\prime \prime}$ & $103^{\circ} 14^{\prime} 58^{\prime \prime}$ & 4,196 & -- \\
\hline 9 & 341935103161901 & $34^{\circ} 19^{\prime} 35^{\prime \prime}$ & $103^{\circ} 16^{\prime} 21^{\prime \prime}$ & 4,223 & -- \\
\hline 10 & 341936103155801 & $34^{\circ} 19^{\prime} 36^{\prime \prime}$ & $103^{\circ} 16^{\prime} 00^{\prime \prime}$ & 4,221 & -- \\
\hline 11 & 341943103204001 & $34^{\circ} 19^{\prime} 43^{\prime \prime}$ & $103^{\circ} 20^{\prime} 42^{\prime \prime}$ & 4,196 & -- \\
\hline 12 & 341943103234701 & $34^{\circ} 19^{\prime} 43^{\prime \prime}$ & $103^{\circ} 23^{\prime} 49^{\prime \prime}$ & 4,202 & -- \\
\hline 13 & 341944103141001 & $34^{\circ} 19^{\prime} 44^{\prime \prime}$ & $103^{\circ} 14^{\prime} 12^{\prime \prime}$ & 4,159 & 300 \\
\hline 14 & 341954103170101 & $34^{\circ} 19^{\prime} 54^{\prime \prime}$ & $103^{\circ} 17^{\prime} 03^{\prime \prime}$ & 4,214 & 331 \\
\hline 15 & 341956103211101 & $34^{\circ} 19^{\prime} 56^{\prime \prime}$ & $103^{\circ} 21^{\prime} 13^{\prime \prime}$ & 4,206 & 199 \\
\hline 16 & 342000103141801 & $34^{\circ} 20^{\prime} 00^{\prime \prime}$ & $103^{\circ} 14^{\prime} 20^{\prime \prime}$ & 4,186 & -- \\
\hline 17 & 342002103141801 & $34^{\circ} 20^{\prime} 02^{\prime \prime}$ & $103^{\circ} 14^{\prime} 20^{\prime \prime}$ & 4,189 & -- \\
\hline 18 & 342010103140801 & $34^{\circ} 20^{\prime} 10^{\prime \prime}$ & $103^{\circ} 14^{\prime} 10^{\prime \prime}$ & 4,187 & 368 \\
\hline 19 & 342011103173301 & $34^{\circ} 20^{\prime} 11^{\prime \prime}$ & $103^{\circ} 17^{\prime} 35^{\prime \prime}$ & 4,230 & -- \\
\hline 20 & 342011103191701 & $34^{\circ} 20^{\prime} 11^{\prime \prime}$ & $103^{\circ} 19^{\prime} 19^{\prime \prime}$ & 4,221 & 244 \\
\hline 21 & 342015103231501 & $34^{\circ} 20^{\prime} 15^{\prime \prime}$ & $103^{\circ} 23^{\prime} 17^{\prime \prime}$ & 4,237 & -- \\
\hline 22 & 342025103211601 & $34^{\circ} 20^{\prime} 25^{\prime \prime}$ & $103^{\circ} 21^{\prime} 18^{\prime \prime}$ & 4,226 & -- \\
\hline 23 & 342033103155801 & $34^{\circ} 20^{\prime} 33^{\prime \prime}$ & $103^{\circ} 16^{\prime} 00^{\prime \prime}$ & 4,235 & 370 \\
\hline 24 & 342034103170101 & $34^{\circ} 20^{\prime} 34^{\prime \prime}$ & $103^{\circ} 17^{\prime} 03^{\prime \prime}$ & 4,242 & -- \\
\hline 25 & 342034103175101 & $34^{\circ} 20^{\prime} 34^{\prime \prime}$ & $103^{\circ} 17^{\prime} 53^{\prime \prime}$ & 4,244 & -- \\
\hline 26 & 342035103220201 & $34^{\circ} 20^{\prime} 35^{\prime \prime}$ & $103^{\circ} 22^{\prime} 04^{\prime \prime}$ & 4,235 & -- \\
\hline 27 & 342036103201301 & $34^{\circ} 20^{\prime} 36^{\prime \prime}$ & $103^{\circ} 20^{\prime} 15^{\prime \prime}$ & 4,239 & 250 \\
\hline 28 & 342036103220001 & $34^{\circ} 20^{\prime} 36^{\prime \prime}$ & $103^{\circ} 22^{\prime} 02^{\prime \prime}$ & 4,236 & 235 \\
\hline 29 & 342037103231201 & $34^{\circ} 20^{\prime} 37^{\prime \prime}$ & $103^{\circ} 23^{\prime} 14^{\prime \prime}$ & 4,263 & -- \\
\hline 30 & 342047103183501 & $34^{\circ} 20^{\prime} 47^{\prime \prime}$ & $103^{\circ} 18^{\prime} 37^{\prime \prime}$ & 4,238 & 293 \\
\hline 31 & 342047103232001 & $34^{\circ} 20^{\prime} 47^{\prime \prime}$ & $103^{\circ} 23^{\prime} 22^{\prime \prime}$ & 4,269 & -- \\
\hline 32 & 342048103145801 & $34^{\circ} 20^{\prime} 48^{\prime \prime}$ & $103^{\circ} 15^{\prime} 00^{\prime \prime}$ & 4,231 & 402 \\
\hline 33 & 342052103162901 & $34^{\circ} 20^{\prime} 52^{\prime \prime}$ & $103^{\circ} 16^{\prime} 31^{\prime \prime}$ & 4,239 & -- \\
\hline 34 & 342058103211401 & $34^{\circ} 20^{\prime} 58^{\prime \prime}$ & $103^{\circ} 21^{\prime} 16^{\prime \prime}$ & 4,248 & 270 \\
\hline 35 & 342100103170101 & $34^{\circ} 21^{\prime} 00^{\prime \prime}$ & $103^{\circ} 17^{\prime} 03^{\prime \prime}$ & 4,252 & 390 \\
\hline 36 & 342113103173401 & $34^{\circ} 21^{\prime} 13^{\prime \prime}$ & $103^{\circ} 17^{\prime} 36^{\prime \prime}$ & 4,254 & 388 \\
\hline 37 & 342114103194801 & $34^{\circ} 21^{\prime} 14^{\prime \prime}$ & $103^{\circ} 19^{\prime} 50^{\prime \prime}$ & 4,250 & -- \\
\hline 38 & 342115103141501 & $34^{\circ} 21^{\prime} 15^{\prime \prime}$ & $103^{\circ} 14^{\prime} 17^{\prime \prime}$ & 4,223 & 360 \\
\hline 39 & 342117103160701 & $34^{\circ} 21^{\prime} 17^{\prime \prime}$ & $103^{\circ} 16^{\prime} 09^{\prime \prime}$ & 4,255 & -- \\
\hline 40 & 342121103142301 & $34^{\circ} 21^{\prime} 21^{\prime \prime}$ & $103^{\circ} 14^{\prime} 25^{\prime \prime}$ & 4,233 & 337 \\
\hline 41 & 342126103164501 & $34^{\circ} 21^{\prime} 26^{\prime \prime}$ & $103^{\circ} 16^{\prime} 47^{\prime \prime}$ & 4,256 & 397 \\
\hline 42 & 342127103185501 & $34^{\circ} 21^{\prime} 27^{\prime \prime}$ & $103^{\circ} 18^{\prime} 57^{\prime \prime}$ & 4,263 & 320 \\
\hline 43 & 342130103161501 & $34^{\circ} 21^{\prime} 30^{\prime \prime}$ & $103^{\circ} 16^{\prime} 17^{\prime \prime}$ & 4,255 & 415 \\
\hline 44 & 342135103211401 & $34^{\circ} 21^{\prime} 35^{\prime \prime}$ & $103^{\circ} 21^{\prime} 16^{\prime \prime}$ & 4,289 & -- \\
\hline 45 & 342135103211402 & $34^{\circ} 21^{\prime} 35^{\prime \prime}$ & $103^{\circ} 21^{\prime} 16^{\prime \prime}$ & 4,289 & 282 \\
\hline 46 & 342140103154401 & $34^{\circ} 21^{\prime} 40^{\prime \prime}$ & $103^{\circ} 15^{\prime} 46^{\prime \prime}$ & 4,255 & 390 \\
\hline 47 & 342140103190501 & $34^{\circ} 21^{\prime} 41^{\prime \prime}$ & $103^{\circ} 19^{\prime} 10^{\prime \prime}$ & 4,262 & 315 \\
\hline
\end{tabular}


Table I-1. Information for selected wells at Cannon Air Force Base and the surrounding area. - Continued

[NAD 83, North American Datum of 1983; NAVD 88, North American Vertical Datum of 1988; ft, feet; bls, below land surface; --, not available]

\begin{tabular}{|c|c|c|c|c|c|}
\hline $\begin{array}{l}\text { Map identifier } \\
\text { (fig. I-1) }\end{array}$ & $\begin{array}{l}\text { U.S. Geological Survey } \\
\text { identification number }\end{array}$ & Latitude (NAD 83) & Longitude (NAD 83) & $\begin{array}{l}\text { Land-surface } \\
\text { altitude (ft above } \\
\text { NAVD 88) }\end{array}$ & Well depth (ft bls) \\
\hline 48 & 342142103221201 & $34^{\circ} 21^{\prime} 42^{\prime \prime}$ & $103^{\circ} 22^{\prime} 14^{\prime \prime}$ & 4,294 & 268 \\
\hline 49 & 342145103232501 & $34^{\circ} 21^{\prime} 45^{\prime \prime}$ & $103^{\circ} 23^{\prime} 27^{\prime \prime}$ & 4,289 & -- \\
\hline 50 & 342147103201501 & $34^{\circ} 21^{\prime} 47^{\prime \prime}$ & $103^{\circ} 20^{\prime} 17^{\prime \prime}$ & 4,261 & -- \\
\hline 51 & 342153103181401 & $34^{\circ} 21^{\prime} 53^{\prime \prime}$ & $103^{\circ} 18^{\prime} 16^{\prime \prime}$ & 4,262 & 364 \\
\hline 52 & 342155103171801 & $34^{\circ} 21^{\prime} 55^{\prime \prime}$ & $103^{\circ} 17^{\prime} 20^{\prime \prime}$ & 4,260 & 375 \\
\hline 53 & 342156103180801 & $34^{\circ} 2156.67^{\prime \prime}$ & $103^{\circ} 18^{\prime} 16.49^{\prime \prime}$ & 4,264 & 360 \\
\hline 54 & 342156103180802 & $34^{\circ} 21^{\prime} 56.24^{\prime \prime}$ & $103^{\circ} 18^{\prime} 12.02^{\prime \prime}$ & 4,261 & 303 \\
\hline 55 & 342157103181101 & $34^{\circ} 21^{\prime} 57.00^{\prime \prime}$ & $103^{\circ} 18^{\prime} 10.69^{\prime \prime}$ & 4,261 & 365 \\
\hline 56 & 342157103181701 & $34^{\circ} 21^{\prime} 57.13^{\prime \prime}$ & $103^{\circ} 18^{\prime} 24.41^{\prime \prime}$ & 4,262 & 355 \\
\hline 57 & 342158103180601 & $34^{\circ} 21^{\prime} 58.94^{\prime \prime}$ & $103^{\circ} 18^{\prime} 10.37^{\prime \prime}$ & 4,262 & 291 \\
\hline 58 & 342200103180901 & $34^{\circ} 22^{\prime} 00.07^{\prime \prime}$ & $103^{\circ} 18^{\prime} 09.47^{\prime \prime}$ & 4,261 & 365 \\
\hline 59 & 342200103181001 & $34^{\circ} 21^{\prime} 59.94^{\prime \prime}$ & $103^{\circ} 18^{\prime} 10.04^{\prime \prime}$ & 4,261 & 287 \\
\hline 60 & 342201103180901 & $34^{\circ} 22^{\prime} 00.98^{\prime \prime}$ & $103^{\circ} 18^{\prime} 09.94^{\prime \prime}$ & 4,261 & 285 \\
\hline 61 & 342203103181001 & $34^{\circ} 22^{\prime} 02.67^{\prime \prime}$ & $103^{\circ} 18^{\prime} 10.33^{\prime \prime}$ & 4,262 & 362 \\
\hline 62 & 342205103181001 & $34^{\circ} 22^{\prime} 04.81^{\prime \prime}$ & $103^{\circ} 18^{\prime} 09.90^{\prime \prime}$ & 4,262 & 365 \\
\hline 63 & 342206103192501 & $34^{\circ} 22^{\prime} 06^{\prime \prime}$ & $103^{\circ} 19^{\prime} 27^{\prime \prime}$ & 4,266 & 318 \\
\hline 64 & 342212103170401 & $34^{\circ} 22^{\prime} 12^{\prime \prime}$ & $103^{\circ} 17^{\prime} 06^{\prime \prime}$ & 4,261 & 355 \\
\hline 65 & 342218103182601 & $34^{\circ} 22^{\prime} 18.91^{\prime \prime}$ & $103^{\circ} 18^{\prime} 31.43^{\prime \prime}$ & 4,264 & 340 \\
\hline 66 & 342219103183101 & $34^{\circ} 22^{\prime} 18.98^{\prime \prime}$ & $103^{\circ} 18^{\prime} 31.39^{\prime \prime}$ & 4,264 & 294 \\
\hline 67 & 342222103194301 & $34^{\circ} 22^{\prime} 22.16^{\prime \prime}$ & $103^{\circ} 19^{\prime} 43.14^{\prime \prime}$ & 4,265 & 340 \\
\hline 68 & 342225103173401 & $34^{\circ} 22^{\prime} 25^{\prime \prime}$ & $103^{\circ} 17^{\prime} 36^{\prime \prime}$ & 4,269 & 365 \\
\hline 69 & 342225103235501 & $34^{\circ} 22^{\prime} 25^{\prime \prime}$ & $103^{\circ} 23^{\prime} 57^{\prime \prime}$ & 4,308 & -- \\
\hline 70 & 342232103211801 & $34^{\circ} 22^{\prime} 32^{\prime \prime}$ & $103^{\circ} 21^{\prime} 20^{\prime \prime}$ & 4,294 & 289 \\
\hline 71 & 342237103155101 & $34^{\circ} 22^{\prime} 37^{\prime \prime}$ & $103^{\circ} 15^{\prime} 53^{\prime \prime}$ & 4,244 & 323 \\
\hline 72 & 342240103170201 & $34^{\circ} 22^{\prime} 40^{\prime \prime}$ & $103^{\circ} 17^{\prime} 04^{\prime \prime}$ & 4,260 & 323 \\
\hline 73 & 342240103175001 & $34^{\circ} 22^{\prime} 40^{\prime \prime}$ & $103^{\circ} 17^{\prime} 52^{\prime \prime}$ & 4,274 & 365 \\
\hline 74 & 342246103172101 & $34^{\circ} 22^{\prime} 46^{\prime \prime}$ & $103^{\circ} 17^{\prime} 23^{\prime \prime}$ & 4,262 & 340 \\
\hline 75 & 342246103204201 & $34^{\circ} 22^{\prime} 46^{\prime \prime}$ & $103^{\circ} 20^{\prime} 44^{\prime \prime}$ & 4,297 & -- \\
\hline 76 & 342258103150501 & $34^{\circ} 22^{\prime} 58^{\prime \prime}$ & $103^{\circ} 15^{\prime} 07^{\prime \prime}$ & 4,258 & 338 \\
\hline 77 & 342300103175001 & $34^{\circ} 23^{\prime} 00.33^{\prime \prime}$ & $103^{\circ} 17^{\prime} 50.57^{\prime \prime}$ & 4,270 & 370 \\
\hline 78 & 342304103174401 & $34^{\circ} 23^{\prime} 00.24^{\prime \prime}$ & $103^{\circ} 17^{\prime} 50.39^{\prime \prime}$ & 4,269 & 304 \\
\hline 79 & 342306103142101 & $34^{\circ} 23^{\prime} 06^{\prime \prime}$ & $103^{\circ} 14^{\prime} 23^{\prime \prime}$ & 4,267 & 350 \\
\hline 80 & 342306103221801 & $34^{\circ} 23^{\prime} 06^{\prime \prime}$ & $103^{\circ} 22^{\prime} 20^{\prime \prime}$ & 4,314 & -- \\
\hline 81 & 342307103181601 & $34^{\circ} 23^{\prime} 07.71^{\prime \prime}$ & $103^{\circ} 18^{\prime} 17.42^{\prime \prime}$ & 4,276 & 372 \\
\hline 82 & 342309103180601 & $34^{\circ} 23^{\prime} 10.42^{\prime \prime}$ & $103^{\circ} 18^{\prime} 07.99^{\prime \prime}$ & 4,271 & 295 \\
\hline 83 & 342310103160901 & $34^{\circ} 23^{\prime} 10^{\prime \prime}$ & $103^{\circ} 16^{\prime} 11^{\prime \prime}$ & 4,276 & 332 \\
\hline 84 & 342310103165901 & $34^{\circ} 23^{\prime} 10^{\prime \prime}$ & $103^{\circ} 17^{\prime} 01^{\prime \prime}$ & 4,276 & 335 \\
\hline 85 & 342310103180801 & $34^{\circ} 23^{\prime} 10.49^{\prime \prime}$ & $103^{\circ} 18^{\prime} 08.24^{\prime \prime}$ & 4,271 & 370 \\
\hline 86 & 342313103180801 & $34^{\circ} 23^{\prime} 12.85^{\prime \prime}$ & $103^{\circ} 18^{\prime} 12.06^{\prime \prime}$ & 4,276 & 368 \\
\hline 87 & 342317103174701 & $34^{\circ} 23^{\prime} 18.11^{\prime \prime}$ & $103^{\circ} 17^{\prime} 46.57^{\prime \prime}$ & 4,266 & 297 \\
\hline 88 & 342320103142501 & $34^{\circ} 23^{\prime} 20^{\prime \prime}$ & $103^{\circ} 14^{\prime} 27^{\prime \prime}$ & 4,267 & -- \\
\hline 89 & 342321103181001 & $34^{\circ} 23^{\prime} 21.29^{\prime \prime}$ & $103^{\circ} 18^{\prime} 14.29^{\prime \prime}$ & 4,275 & 355 \\
\hline 90 & 342323103145601 & $34^{\circ} 23^{\prime} 23^{\prime \prime}$ & $103^{\circ} 14^{\prime} 58^{\prime \prime}$ & 4,279 & -- \\
\hline 91 & 342323103180801 & $34^{\circ} 23^{\prime} 23.50^{\prime \prime}$ & $103^{\circ} 18^{\prime} 08.21^{\prime \prime}$ & 4,272 & -- \\
\hline 92 & 342324103211401 & $34^{\circ} 23^{\prime} 24^{\prime \prime}$ & $103^{\circ} 21^{\prime} 16^{\prime \prime}$ & 4,317 & 415 \\
\hline 93 & 342325103233601 & $34^{\circ} 23^{\prime} 25^{\prime \prime}$ & $103^{\circ} 23^{\prime} 38^{\prime \prime}$ & 4,334 & 328 \\
\hline
\end{tabular}


Table I-1. Information for selected wells at Cannon Air Force Base and the surrounding area.-Continued

[NAD 83, North American Datum of 1983; NAVD 88, North American Vertical Datum of 1988; ft, feet; bls, below land surface; --, not available]

\begin{tabular}{|c|c|c|c|c|c|}
\hline $\begin{array}{l}\text { Map identifier } \\
\text { (fig. I-1) }\end{array}$ & $\begin{array}{l}\text { U.S. Geological Survey } \\
\text { identification number }\end{array}$ & Latitude (NAD 83) & Longitude (NAD 83) & $\begin{array}{c}\text { Land-surface } \\
\text { altitude (ft above } \\
\text { NAVD 88) }\end{array}$ & Well depth (ft bls) \\
\hline 94 & 342328103182401 & $34^{\circ} 23^{\prime} 26.51^{\prime \prime}$ & $103^{\circ} 18^{\prime} 26.21^{\prime \prime}$ & 4,280 & 366 \\
\hline 95 & 342338103203701 & $34^{\circ} 23^{\prime} 38^{\prime \prime}$ & $103^{\circ} 20^{\prime} 39^{\prime \prime}$ & 4,329 & 365 \\
\hline 96 & 342338103210701 & $34^{\circ} 23^{\prime} 38^{\prime \prime}$ & $103^{\circ} 21^{\prime} 09^{\prime \prime}$ & 4,337 & -- \\
\hline 97 & 342344103224901 & $34^{\circ} 23^{\prime} 44^{\prime \prime}$ & $103^{\circ} 22^{\prime} 51^{\prime \prime}$ & 4,330 & 360 \\
\hline 98 & 342348103175801 & $34^{\circ} 23^{\prime} 48.64^{\prime \prime}$ & $103^{\circ} 17^{\prime} 57.62^{\prime \prime}$ & 4,297 & 381 \\
\hline 99 & 342353103214601 & $34^{\circ} 23^{\prime} 53^{\prime \prime}$ & $103^{\circ} 21^{\prime} 48^{\prime \prime}$ & 4,341 & 370 \\
\hline 100 & 342358103151601 & $34^{\circ} 23^{\prime} 58^{\prime \prime}$ & $103^{\circ} 15^{\prime} 18^{\prime \prime}$ & 4,309 & 430 \\
\hline 101 & 342401103155901 & $34^{\circ} 24^{\prime} 01^{\prime \prime}$ & $103^{\circ} 16^{\prime} 01^{\prime \prime}$ & 4,314 & 394 \\
\hline 102 & 342404103210401 & $34^{\circ} 24^{\prime} 04^{\prime \prime}$ & $103^{\circ} 21^{\prime} 06^{\prime \prime}$ & 4,353 & 386 \\
\hline 103 & 342405103170301 & $34^{\circ} 24^{\prime} 05^{\prime \prime}$ & $103^{\circ} 17^{\prime} 05^{\prime \prime}$ & 4,305 & 334 \\
\hline 104 & 342405103235001 & $34^{\circ} 24^{\prime} 05^{\prime \prime}$ & $103^{\circ} 23^{\prime} 52^{\prime \prime}$ & 4,357 & 278 \\
\hline 105 & 342406103183401 & $34^{\circ} 24^{\prime} 06^{\prime \prime}$ & $103^{\circ} 18^{\prime} 36^{\prime \prime}$ & 4,325 & -- \\
\hline 106 & 342418103180601 & $34^{\circ} 24^{\prime} 18^{\prime \prime}$ & $103^{\circ} 18^{\prime} 08^{\prime \prime}$ & 4,315 & 350 \\
\hline 107 & 342418103201201 & $34^{\circ} 24^{\prime} 18.00^{\prime \prime}$ & $103^{\circ} 20^{\prime} 12.59^{\prime \prime}$ & 4,325 & 370 \\
\hline 108 & 342419103232301 & $34^{\circ} 24^{\prime} 19^{\prime \prime}$ & $103^{\circ} 23^{\prime} 25^{\prime \prime}$ & 4,362 & 372 \\
\hline 109 & 342424103220901 & $34^{\circ} 24^{\prime} 24^{\prime \prime}$ & $103^{\circ} 22^{\prime} 11^{\prime \prime}$ & 4,363 & 356 \\
\hline 110 & 342435103223501 & $34^{\circ} 24^{\prime} 35^{\prime \prime}$ & $103^{\circ} 22^{\prime} 37^{\prime \prime}$ & 4,364 & -- \\
\hline 111 & 342442103213601 & $34^{\circ} 24^{\prime} 42^{\prime \prime}$ & $103^{\circ} 21^{\prime} 38^{\prime \prime}$ & 4,365 & -- \\
\hline 112 & 342453103141901 & $34^{\circ} 24^{\prime} 53^{\prime \prime}$ & $103^{\circ} 14^{\prime} 21^{\prime \prime}$ & 4,319 & 415 \\
\hline 113 & 342455103183301 & $34^{\circ} 24^{\prime} 55^{\prime \prime}$ & $103^{\circ} 18^{\prime} 35^{\prime \prime}$ & 4,344 & 375 \\
\hline 114 & 342456103195201 & $34^{\circ} 24^{\prime} 56^{\prime \prime}$ & $103^{\circ} 19^{\prime} 54^{\prime \prime}$ & 4,354 & 418 \\
\hline 115 & 342457103213901 & $34^{\circ} 24^{\prime} 57^{\prime \prime}$ & $103^{\circ} 21^{\prime} 41^{\prime \prime}$ & 4,365 & 430 \\
\hline 116 & 342505103151801 & $34^{\circ} 24^{\prime} 53^{\prime \prime}$ & $103^{\circ} 15^{\prime} 24^{\prime \prime}$ & 4,336 & 419 \\
\hline 117 & 342506103164701 & $34^{\circ} 25^{\prime} 06^{\prime \prime}$ & $103^{\circ} 16^{\prime} 49^{\prime \prime}$ & 4,345 & 405 \\
\hline 118 & 342506103174201 & $34^{\circ} 25^{\prime} 06^{\prime \prime}$ & $103^{\circ} 17^{\prime} 44^{\prime \prime}$ & 4,349 & 400 \\
\hline 119 & 342509103203801 & $34^{\circ} 25^{\prime} 09^{\prime \prime}$ & $103^{\circ} 20^{\prime} 40^{\prime \prime}$ & 4,369 & 432 \\
\hline 120 & 342519103230101 & $34^{\circ} 25^{\prime} 19^{\prime \prime}$ & $103^{\circ} 23^{\prime} 03^{\prime \prime}$ & 4,394 & 392 \\
\hline 121 & 342520103165601 & $34^{\circ} 25^{\prime} 20^{\prime \prime}$ & $103^{\circ} 16^{\prime} 58^{\prime \prime}$ & 4,356 & 400 \\
\hline 122 & 342521103221801 & $34^{\circ} 25^{\prime} 21^{\prime \prime}$ & $103^{\circ} 22^{\prime} 20^{\prime \prime}$ & 4,381 & 441 \\
\hline 123 & 342522103203801 & $34^{\circ} 25^{\prime} 22^{\prime \prime}$ & $103^{\circ} 20^{\prime} 40^{\prime \prime}$ & 4,373 & 375 \\
\hline 124 & 342523103225301 & $34^{\circ} 25^{\prime} 23^{\prime \prime}$ & $103^{\circ} 22^{\prime} 55^{\prime \prime}$ & 4,391 & 432 \\
\hline 125 & 342532103180501 & $34^{\circ} 25^{\prime} 32^{\prime \prime}$ & $103^{\circ} 18^{\prime} 07^{\prime \prime}$ & 4,362 & 421 \\
\hline 126 & 342533103145601 & $34^{\circ} 25^{\prime} 33^{\prime \prime}$ & $103^{\circ} 14^{\prime} 58^{\prime \prime}$ & 4,335 & 412 \\
\hline 127 & 342535103190201 & $34^{\circ} 25^{\prime} 35^{\prime \prime}$ & $103^{\circ} 19^{\prime} 04^{\prime \prime}$ & 4,360 & -- \\
\hline 128 & 342535103211501 & $34^{\circ} 25^{\prime} 35^{\prime \prime}$ & $103^{\circ} 21^{\prime} 17^{\prime \prime}$ & 4,391 & -- \\
\hline 129 & 342547103190201 & $34^{\circ} 26^{\prime} 01^{\prime \prime}$ & $103^{\circ} 19^{\prime} 10^{\prime \prime}$ & 4,375 & 385 \\
\hline 130 & 342548103193601 & $34^{\circ} 25^{\prime} 48^{\prime \prime}$ & $103^{\circ} 19^{\prime} 38^{\prime \prime}$ & 4,384 & -- \\
\hline 131 & 342551103232201 & $34^{\circ} 25^{\prime} 51^{\prime \prime}$ & $103^{\circ} 23^{\prime} 24^{\prime \prime}$ & 4,400 & -- \\
\hline 132 & 342559103155601 & $34^{\circ} 25^{\prime} 59^{\prime \prime}$ & $103^{\circ} 15^{\prime} 58^{\prime \prime}$ & 4,357 & -- \\
\hline 133 & 342559103165301 & $34^{\circ} 25^{\prime} 59^{\prime \prime}$ & $103^{\circ} 16^{\prime} 55^{\prime \prime}$ & 4,366 & -- \\
\hline 134 & 342559103183401 & $34^{\circ} 25^{\prime} 59^{\prime \prime}$ & $103^{\circ} 18^{\prime} 36^{\prime \prime}$ & 4,370 & 388 \\
\hline 135 & 342600103232001 & $34^{\circ} 26^{\prime} 00^{\prime \prime}$ & $103^{\circ} 23^{\prime} 22^{\prime \prime}$ & 4,409 & 446 \\
\hline 136 & 342609103172701 & $34^{\circ} 26^{\prime} 09^{\prime \prime}$ & $103^{\circ} 17^{\prime} 29^{\prime \prime}$ & 4,381 & 412 \\
\hline 137 & 342615103220701 & $34^{\circ} 26^{\prime} 15^{\prime \prime}$ & $103^{\circ} 22^{\prime} 09^{\prime \prime}$ & 4,424 & 406 \\
\hline 138 & 342626103195301 & $34^{\circ} 26^{\prime} 26^{\prime \prime}$ & $103^{\circ} 19^{\prime} 55^{\prime \prime}$ & 4,394 & 387 \\
\hline 139 & 342626103204101 & $34^{\circ} 26^{\prime} 26^{\prime \prime}$ & $103^{\circ} 20^{\prime} 43^{\prime \prime}$ & 4,407 & 402 \\
\hline
\end{tabular}


Table I-1. Information for selected wells at Cannon Air Force Base and the surrounding area.-Continued

[NAD 83, North American Datum of 1983; NAVD 88, North American Vertical Datum of 1988; ft, feet; bls, below land surface; --, not available]

\begin{tabular}{|c|c|c|c|c|c|}
\hline $\begin{array}{l}\text { Map identifier } \\
\text { (fig. I-1) }\end{array}$ & $\begin{array}{l}\text { U.S. Geological Survey } \\
\text { identification number }\end{array}$ & Latitude (NAD 83) & Longitude (NAD 83) & $\begin{array}{l}\text { Land-surface } \\
\text { altitude (ft above } \\
\text { NAVD 88) }\end{array}$ & Well depth (ft bls) \\
\hline 140 & 342630103145201 & $34^{\circ} 26^{\prime} 11^{\prime \prime}$ & $103^{\circ} 14^{\prime} 51^{\prime \prime}$ & 4,347 & 387 \\
\hline 141 & 342630103231901 & $34^{\circ} 26^{\prime} 30^{\prime \prime}$ & $103^{\circ} 23^{\prime} 21^{\prime \prime}$ & 4,422 & 433 \\
\hline 142 & 342633103155301 & $34^{\circ} 26^{\prime} 33^{\prime \prime}$ & $103^{\circ} 15^{\prime} 55^{\prime \prime}$ & 4,369 & 396 \\
\hline 143 & 342638103162401 & $34^{\circ} 26^{\prime} 38^{\prime \prime}$ & $103^{\circ} 16^{\prime} 26^{\prime \prime}$ & 4,378 & 395 \\
\hline 144 & 342653103195201 & $34^{\circ} 26^{\prime} 53^{\prime \prime}$ & $103^{\circ} 19^{\prime} 54^{\prime \prime}$ & 4,406 & 415 \\
\hline 145 & 342655103151401 & $34^{\circ} 26^{\prime} 55^{\prime \prime}$ & $103^{\circ} 15^{\prime} 16^{\prime \prime}$ & 4,364 & -- \\
\hline
\end{tabular}

Table I-2. Altitudes of water levels in selected wells at Cannon Air Force Base and the surrounding area.

[Monitoring well, Cannon Air Force Base monitoring well; Primary use of water: I, irrigation; O, observation; S, stock watering; U, unused; Z, other; W, withdrawal; ---, not recorded]

\begin{tabular}{|c|c|c|c|c|c|c|c|}
\hline $\begin{array}{c}\text { Map } \\
\text { identifier } \\
\text { (fig. I-1) }\end{array}$ & $\begin{array}{c}\text { U.S. Geological Survey } \\
\text { identifier }\end{array}$ & Township and range & $\begin{array}{c}\text { Primary } \\
\text { use of } \\
\text { water }\end{array}$ & $\begin{array}{c}\text { Water- } \\
\text { level } \\
\text { date }\end{array}$ & $\begin{array}{c}\text { Altitude } \\
\text { of land } \\
\text { surface } \\
\text { (feet above } \\
\text { NAVD 88) }\end{array}$ & $\begin{array}{c}\text { Water } \\
\text { level } \\
\text { (feet } \\
\text { below } \\
\text { land } \\
\text { surface) }\end{array}$ & $\begin{array}{c}\text { Altitude } \\
\text { of water } \\
\text { level } \\
\text { (feet above } \\
\text { NAVD 88) }\end{array}$ \\
\hline \multirow[t]{5}{*}{1} & 341903103145601 & 01N.35E.11.33333 & 1 & $01 / 09 / 80$ & 4,196 & 203.75 & 3,992 \\
\hline & & & & $01 / 12 / 81$ & 4,196 & 207.55 & 3,988 \\
\hline & & & & $01 / 11 / 82$ & 4,196 & 210.31 & 3,986 \\
\hline & & & & $01 / 10 / 83$ & 4,196 & 213.70 & 3,982 \\
\hline & & & & $01 / 07 / 87$ & 4,196 & 221.84 & 3,974 \\
\hline \multirow[t]{2}{*}{2} & 341913103220001 & 01N.34E.10.31244 & $S$ & $01 / 17 / 62$ & 4,180 & 121.91 & 4,058 \\
\hline & & & & $02 / 02 / 67$ & 4,180 & 120.97 & 4,059 \\
\hline \multirow[t]{2}{*}{3} & 341913103220002 & 01N.34E.10.31244A & $S$ & $01 / 21 / 77$ & 4,180 & 133.37 & 4,047 \\
\hline & & & & $03 / 10 / 82$ & 4,180 & 138.44 & 4,042 \\
\hline \multirow[t]{3}{*}{4} & 341915103180501 & 01N.35E.07.42224 & $S$ & $01 / 13 / 61$ & 4,197 & 157.03 & 4,040 \\
\hline & & & & $01 / 17 / 62$ & 4,197 & 157.66 & 4,039 \\
\hline & & & & $01 / 28 / 67$ & 4,197 & 161.45 & 4,036 \\
\hline \multirow[t]{3}{*}{5} & 341918103175001 & 01N.35E.08.13444 & $U$ & $01 / 13 / 61$ & 4,213 & 175.70 & 4,037 \\
\hline & & & & $01 / 17 / 62$ & 4,213 & 180.14 & 4,033 \\
\hline & & & & $01 / 28 / 67$ & 4,213 & 181.22 & 4,032 \\
\hline \multirow[t]{4}{*}{6} & 341919103175001 & 01N.35E.08.13442 & I & $01 / 18 / 77$ & 4,213 & 198.33 & 4,015 \\
\hline & & & & $03 / 09 / 82$ & 4,213 & 206.88 & 4,006 \\
\hline & & & & $01 / 08 / 87$ & 4,213 & 213.86 & 3,999 \\
\hline & & & & $02 / 20 / 97$ & 4,213 & 229.89 & 3,983 \\
\hline \multirow[t]{2}{*}{7} & 341929103231601 & 01N.34E.08.42222 & 1 & $03 / 30 / 82$ & 4,176 & 111.37 & 4,065 \\
\hline & & & & $02 / 06 / 87$ & 4,176 & 113.39 & 4,063 \\
\hline \multirow[t]{7}{*}{8} & 341935103145601 & 01N.35E.11.1331 & $U$ & $01 / 19 / 84$ & 4,196 & 223.04 & 3,973 \\
\hline & & & & $01 / 13 / 85$ & 4,196 & 224.42 & 3,972 \\
\hline & & & & $01 / 13 / 86$ & 4,196 & 226.14 & 3,970 \\
\hline & & & & $01 / 13 / 87$ & 4,196 & 228.43 & 3,968 \\
\hline & & & & $01 / 13 / 88$ & 4,196 & 230.35 & 3,966 \\
\hline & & & & $01 / 04 / 90$ & 4,196 & 235.23 & 3,961 \\
\hline & & & & $01 / 05 / 91$ & 4,196 & 239.02 & 3,957 \\
\hline
\end{tabular}


Table I-2. Altitudes of water levels in selected wells at Cannon Air Force Base and the surrounding area.-Continued [Monitoring well, Cannon Air Force Base monitoring well; Primary use of water: I, irrigation; O, observation; S, stock watering; U, unused; Z, other; W, withdrawal; ---, not recorded]

\begin{tabular}{|c|c|c|c|c|c|c|c|}
\hline $\begin{array}{c}\text { Map } \\
\text { identifier } \\
\text { (fig. I-1) }\end{array}$ & $\begin{array}{c}\text { U.S. Geological Survey } \\
\text { identifier }\end{array}$ & Township and range & $\begin{array}{l}\text { Primary } \\
\text { use of } \\
\text { water }\end{array}$ & $\begin{array}{l}\text { Water- } \\
\text { level } \\
\text { date }\end{array}$ & $\begin{array}{l}\text { Altitude } \\
\text { of land } \\
\text { surface } \\
\text { (feet above } \\
\text { NAVD 88) }\end{array}$ & $\begin{array}{c}\text { Water } \\
\text { level } \\
\text { (feet } \\
\text { below } \\
\text { land } \\
\text { surface) }\end{array}$ & $\begin{array}{c}\text { Altitude } \\
\text { of water } \\
\text { level } \\
\text { (feet above } \\
\text { NAVD 88) }\end{array}$ \\
\hline & & & & $01 / 04 / 92$ & 4,196 & 242.00 & 3,954 \\
\hline & & & & $01 / 05 / 93$ & 4,196 & 256.54 & 3,939 \\
\hline & & & & $01 / 05 / 94$ & 4,196 & 265.10 & 3,931 \\
\hline & & & & $01 / 08 / 95$ & 4,196 & 255.45 & 3,941 \\
\hline & & & & $01 / 11 / 96$ & 4,196 & 261.19 & 3,935 \\
\hline & & & & $01 / 24 / 97$ & 4,196 & 265.26 & 3,931 \\
\hline & & & & 01/07/98 & 4,196 & 269.05 & 3,927 \\
\hline 9 & 341935103161901 & 01N.35E.09.21412 & I & $01 / 25 / 67$ & 4,223 & 204.93 & 4,018 \\
\hline \multirow[t]{5}{*}{10} & 341936103155801 & 01N.35E.10.113111 & I & $03 / 13 / 72$ & 4,221 & 208.99 & 4,012 \\
\hline & & & & $01 / 07 / 77$ & 4,221 & 219.73 & 4,001 \\
\hline & & & & 03/09/82 & 4,221 & 233.52 & 3,987 \\
\hline & & & & 01/07/87 & 4,221 & 243.09 & 3,978 \\
\hline & & & & 02/19/97 & 4,221 & 273.56 & 3,947 \\
\hline 11 & 341943103204001 & 01N.34E.11.21113 & --- & $01 / 17 / 62$ & 4,196 & 138.20 & 4,058 \\
\hline \multirow[t]{2}{*}{12} & 341943103234701 & 01N.34E.08.211143 & $S$ & $01 / 12 / 61$ & 4,202 & 131.53 & 4,070 \\
\hline & & & & $01 / 17 / 62$ & 4,202 & 129.68 & 4,072 \\
\hline \multirow[t]{3}{*}{13} & 341944103141001 & 01N.35E.11.232 & I & 01/08/94 & 4,159 & 218.42 & 3,941 \\
\hline & & & & $01 / 08 / 95$ & 4,159 & 224.87 & 3,934 \\
\hline & & & & $01 / 24 / 97$ & 4,159 & 235.58 & 3,923 \\
\hline \multirow[t]{2}{*}{14} & 341954103170101 & 01N.35E.09.11111 & U & 03/16/82 & 4,214 & 214.50 & 4,000 \\
\hline & & & & $01 / 07 / 87$ & 4,214 & 223.50 & 3,991 \\
\hline 15 & 341956103211101 & 01 N.34E.03.40000 & 1 & 03/26/87 & 4,206 & 166.01 & 4,040 \\
\hline 16 & 342000103141801 & 01N.35E.02.433 & I & --- & 4,186 & --- & -- \\
\hline \multirow[t]{2}{*}{17} & 342002103141801 & 01N.35E.02.43144 & I & 03/16/82 & 4,189 & 211.72 & 3,977 \\
\hline & & & & 03/03/87 & 4,189 & 221.16 & 3,968 \\
\hline 18 & 342010103140801 & 01N.35E.02.42333 & I & $12 / 10 / 92$ & 4,187 & 234.00 & 3,953 \\
\hline \multirow[t]{2}{*}{19} & 342011103173301 & 01N.35E.05.23331 & $S$ & $02 / 27 / 62$ & 4,230 & 193.44 & 4,037 \\
\hline & & & & $01 / 28 / 67$ & 4,230 & 202.28 & 4,028 \\
\hline \multirow[t]{9}{*}{20} & 342011103191701 & 01N.34E.01.24344 & I & 01/19/77 & 4,221 & 193.75 & 4,027 \\
\hline & & & & 03/30/82 & 4,221 & 198.30 & 4,023 \\
\hline & & & & 01/08/87 & 4,221 & 202.45 & 4,019 \\
\hline & & & & $01 / 04 / 91$ & 4,221 & 217.72 & 4,003 \\
\hline & & & & $01 / 03 / 92$ & 4,221 & 218.51 & 4,002 \\
\hline & & & & $01 / 05 / 93$ & 4,221 & 219.20 & 4,002 \\
\hline & & & & $01 / 05 / 94$ & 4,221 & 220.28 & 4,001 \\
\hline & & & & $01 / 04 / 95$ & 4,221 & 221.85 & 3,999 \\
\hline & & & & $01 / 23 / 97$ & 4,221 & 223.61 & 3,997 \\
\hline \multirow[t]{3}{*}{21} & 342015103231501 & 01N.34E.04.133322 & S & $01 / 21 / 77$ & 4,237 & 169.56 & 4,067 \\
\hline & & & & 03/30/82 & 4,237 & 172.76 & 4,064 \\
\hline & & & & 02/06/87 & 4,237 & 175.52 & 4,061 \\
\hline \multirow[t]{2}{*}{22} & 342025103211601 & 01N.34E.03.22443 & $S$ & $01 / 12 / 60$ & 4,226 & 130.84 & 4,095 \\
\hline & & & & $01 / 12 / 61$ & 4,226 & 140.67 & 4,085 \\
\hline
\end{tabular}


Table I-2. Altitudes of water levels in selected wells at Cannon Air Force Base and the surrounding area.-Continued [Monitoring well, Cannon Air Force Base monitoring well; Primary use of water: I, irrigation; O, observation; S, stock watering; U, unused; Z, other; W, withdrawal; ---, not recorded]

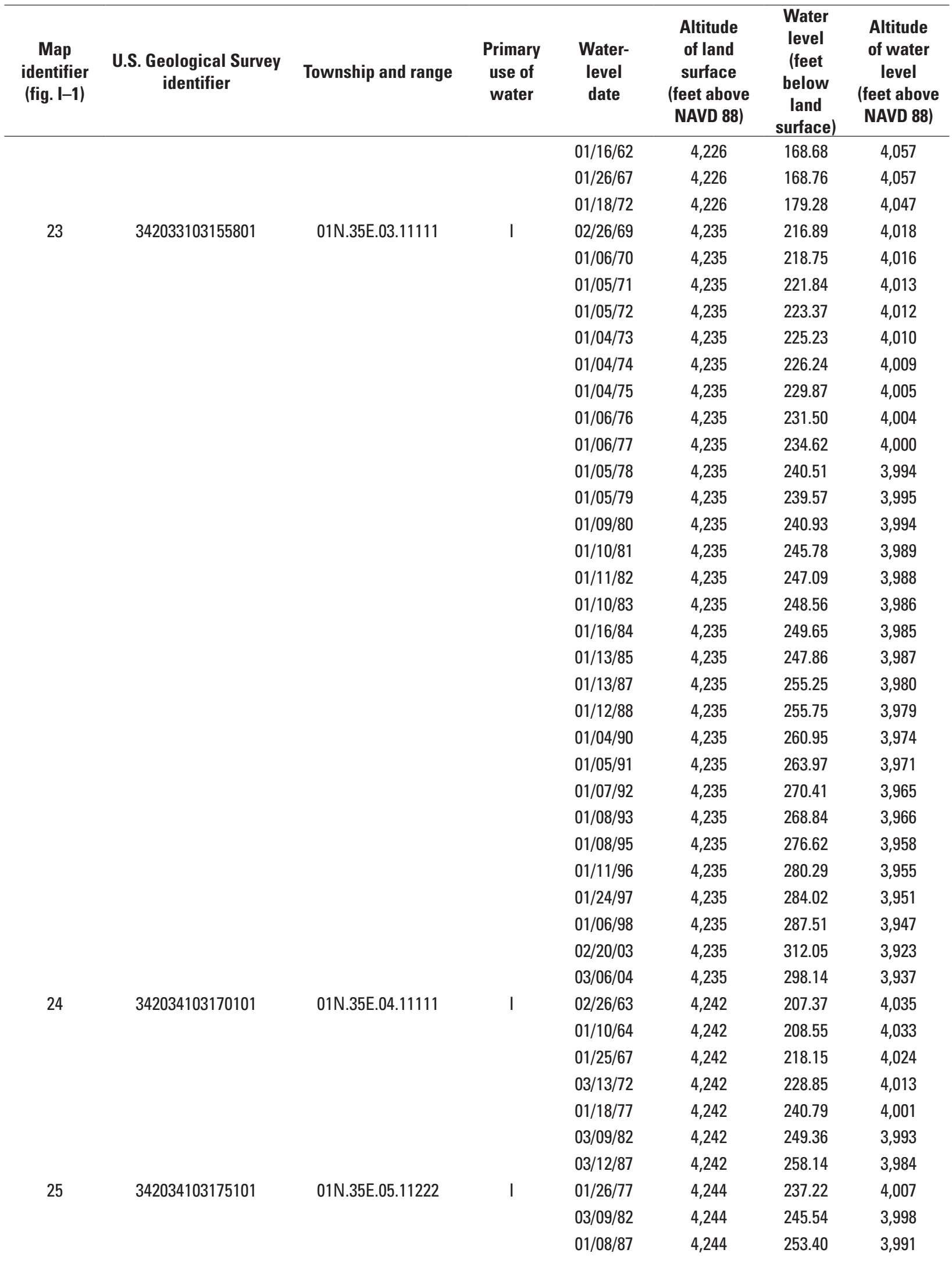


Table I-2. Altitudes of water levels in selected wells at Cannon Air Force Base and the surrounding area.—Continued [Monitoring well, Cannon Air Force Base monitoring well; Primary use of water: I, irrigation; O, observation; S, stock watering; U, unused; Z, other; W, withdrawal; ---, not recorded]

\begin{tabular}{|c|c|c|c|c|c|c|c|}
\hline $\begin{array}{c}\text { Map } \\
\text { identifier } \\
\text { (fig. I-1) }\end{array}$ & $\begin{array}{l}\text { U.S. Geological Survey } \\
\text { identifier }\end{array}$ & Township and range & $\begin{array}{c}\text { Primary } \\
\text { use of } \\
\text { water }\end{array}$ & $\begin{array}{c}\text { Water- } \\
\text { level } \\
\text { date }\end{array}$ & $\begin{array}{c}\text { Altitude } \\
\text { of land } \\
\text { surface } \\
\text { (feet above } \\
\text { NAVD 88) }\end{array}$ & $\begin{array}{c}\text { Water } \\
\text { level } \\
\text { (feet } \\
\text { below } \\
\text { land } \\
\text { surface) }\end{array}$ & $\begin{array}{c}\text { Altitude } \\
\text { of water } \\
\text { level } \\
\text { (feet above } \\
\text { NAVD 88) }\end{array}$ \\
\hline & & & & $02 / 07 / 97$ & 4,244 & 283.97 & 3,960 \\
\hline & & & & 03/06/04 & 4,244 & 302.36 & 3,942 \\
\hline \multirow[t]{2}{*}{26} & 342035103220201 & 01N.34E.03.11224 & S & $01 / 17 / 62$ & 4,235 & 173.56 & 4,061 \\
\hline & & & & $01 / 26 / 67$ & 4,235 & 172.47 & 4,063 \\
\hline \multirow[t]{4}{*}{27} & 342036103201301 & 01N.34E.02.222221 & I & $12 / 16 / 71$ & 4,239 & 197.76 & 4,041 \\
\hline & & & & $01 / 19 / 77$ & 4,239 & 202.38 & 4,037 \\
\hline & & & & $03 / 30 / 82$ & 4,239 & 206.82 & 4,032 \\
\hline & & & & $03 / 11 / 87$ & 4,239 & 209.62 & 4,029 \\
\hline \multirow[t]{33}{*}{28} & 342036103220001 & 01N.34E.03.12111 & 1 & $01 / 10 / 67$ & 4,236 & 172.47 & 4,064 \\
\hline & & & & $02 / 01 / 68$ & 4,236 & 175.10 & 4,061 \\
\hline & & & & $01 / 07 / 69$ & 4,236 & 176.77 & 4,059 \\
\hline & & & & $01 / 06 / 70$ & 4,236 & 179.39 & 4,057 \\
\hline & & & & $01 / 05 / 71$ & 4,236 & 183.42 & 4,053 \\
\hline & & & & $12 / 16 / 71$ & 4,236 & 182.08 & 4,054 \\
\hline & & & & $01 / 05 / 72$ & 4,236 & 188.24 & 4,048 \\
\hline & & & & $01 / 04 / 73$ & 4,236 & 181.26 & 4,055 \\
\hline & & & & $01 / 03 / 74$ & 4,236 & 186.72 & 4,049 \\
\hline & & & & $01 / 03 / 75$ & 4,236 & 184.78 & 4,051 \\
\hline & & & & $01 / 06 / 76$ & 4,236 & 187.37 & 4,049 \\
\hline & & & & $01 / 05 / 77$ & 4,236 & 185.49 & 4,051 \\
\hline & & & & $01 / 05 / 78$ & 4,236 & 189.62 & 4,046 \\
\hline & & & & $01 / 05 / 79$ & 4,236 & 187.66 & 4,048 \\
\hline & & & & $01 / 07 / 80$ & 4,236 & 190.34 & 4,046 \\
\hline & & & & $01 / 10 / 81$ & 4,236 & 189.65 & 4,046 \\
\hline & & & & $01 / 11 / 82$ & 4,236 & 188.97 & 4,047 \\
\hline & & & & $01 / 10 / 83$ & 4,236 & 190.33 & 4,046 \\
\hline & & & & $01 / 18 / 84$ & 4,236 & 191.20 & 4,045 \\
\hline & & & & $01 / 13 / 85$ & 4,236 & 190.40 & 4,046 \\
\hline & & & & 01/09/87 & 4,236 & 191.00 & 4,045 \\
\hline & & & & $01 / 12 / 87$ & 4,236 & 191.00 & 4,045 \\
\hline & & & & $01 / 03 / 90$ & 4,236 & 190.83 & 4,045 \\
\hline & & & & $01 / 04 / 91$ & 4,236 & 191.27 & 4,045 \\
\hline & & & & $01 / 02 / 92$ & 4,236 & 191.08 & 4,045 \\
\hline & & & & $01 / 05 / 93$ & 4,236 & 191.00 & 4,045 \\
\hline & & & & $01 / 05 / 94$ & 4,236 & 190.99 & 4,045 \\
\hline & & & & $01 / 04 / 95$ & 4,236 & 191.97 & 4,044 \\
\hline & & & & $01 / 11 / 96$ & 4,236 & 191.98 & 4,044 \\
\hline & & & & $01 / 24 / 97$ & 4,236 & 192.23 & 4,044 \\
\hline & & & & $02 / 02 / 98$ & 4,236 & 192.14 & 4,044 \\
\hline & & & & $02 / 20 / 03$ & 4,236 & 205.98 & 4,030 \\
\hline & & & & 03/06/04 & 4,236 & 195.53 & 4,040 \\
\hline 29 & 342037103231201 & 01N.34E.04.11122 & U & $01 / 26 / 67$ & 4,263 & 190.80 & 4,072 \\
\hline
\end{tabular}


Table I-2. Altitudes of water levels in selected wells at Cannon Air Force Base and the surrounding area.-Continued [Monitoring well, Cannon Air Force Base monitoring well; Primary use of water: I, irrigation; O, observation; S, stock watering; U, unused; Z, other; W, withdrawal; ---, not recorded]

\begin{tabular}{|c|c|c|c|c|c|c|c|}
\hline $\begin{array}{c}\text { Map } \\
\text { identifier } \\
\text { (fig. I-1) }\end{array}$ & $\begin{array}{l}\text { U.S. Geological Survey } \\
\text { identifier }\end{array}$ & Township and range & $\begin{array}{c}\text { Primary } \\
\text { use of } \\
\text { water }\end{array}$ & $\begin{array}{c}\text { Water- } \\
\text { level } \\
\text { date }\end{array}$ & $\begin{array}{c}\text { Altitude } \\
\text { of land } \\
\text { surface } \\
\text { (feet above } \\
\text { NAVD 88) }\end{array}$ & $\begin{array}{c}\text { Water } \\
\text { level } \\
\text { (feet } \\
\text { below } \\
\text { land } \\
\text { surface) }\end{array}$ & $\begin{array}{c}\text { Altitude } \\
\text { of water } \\
\text { level } \\
\text { (feet above } \\
\text { NAVD 88) }\end{array}$ \\
\hline & & & & $03 / 27 / 72$ & 4,263 & 193.55 & 4,069 \\
\hline \multirow[t]{2}{*}{30} & 342047103183501 & 01N.35E.06.12222 & I & 03/16/82 & 4,238 & 228.49 & 4,010 \\
\hline & & & & $01 / 08 / 87$ & 4,238 & 233.62 & 4,004 \\
\hline \multirow[t]{4}{*}{31} & 342047103232001 & 02N.34E.32.44242 & $S$ & $01 / 12 / 61$ & 4,269 & 191.00 & 4,078 \\
\hline & & & & $01 / 17 / 62$ & 4,269 & 199.46 & 4,070 \\
\hline & & & & $01 / 12 / 72$ & 4,269 & 198.79 & 4,070 \\
\hline & & & & $01 / 05 / 77$ & 4,269 & 202.17 & 4,067 \\
\hline \multirow[t]{2}{*}{32} & 342048103145801 & 02N.35E.34.40000 & 1 & $01 / 28 / 82$ & 4,231 & 253.99 & 3,977 \\
\hline & & & & $01 / 15 / 87$ & 4,231 & 262.29 & 3,969 \\
\hline 33 & 342052103162901 & 01N.35E.04.211 & I & --- & 4,239 & --- & --- \\
\hline \multirow[t]{2}{*}{34} & 342058103211401 & 02N.34E.35.33131 & I & $02 / 11 / 82$ & 4,248 & 206.16 & 4,042 \\
\hline & & & & $02 / 05 / 87$ & 4,248 & 207.72 & 4,040 \\
\hline 35 & 342100103170101 & 02N.35E.33.31111 & I & $01 / 07 / 77$ & 4,252 & 249.75 & 4,002 \\
\hline \multirow[t]{3}{*}{36} & 342113103173401 & 02N.35E.32.411113 & 1 & $07 / 08 / 75$ & 4,254 & 252.55 & 4,001 \\
\hline & & & & $02 / 16 / 82$ & 4,254 & 262.76 & 3,991 \\
\hline & & & & $01 / 15 / 87$ & 4,254 & 268.88 & 3,985 \\
\hline \multirow[t]{2}{*}{37} & 342114103194801 & 02N.34E.36.32211 & I & $02 / 17 / 82$ & 4,250 & 228.39 & 4,022 \\
\hline & & & & $02 / 05 / 87$ & 4,250 & 230.90 & 4,019 \\
\hline 38 & 342115103141501 & 02N.35E.35.234334 & I & 03/16/93 & 4,223 & 260.00 & 3,963 \\
\hline \multirow[t]{3}{*}{39} & 342117103160701 & 02N.35E.33.22324 & Z & $02 / 27 / 62$ & 4,255 & 226.05 & 4,029 \\
\hline & & & & $01 / 16 / 67$ & 4,255 & 246.90 & 4,008 \\
\hline & & & & $01 / 07 / 77$ & 4,255 & 259.00 & 3,996 \\
\hline \multirow[t]{20}{*}{40} & 342121103142301 & 02N.35E.35.21131 & I & $02 / 27 / 62$ & 4,233 & 208.28 & 4,025 \\
\hline & & & & $01 / 17 / 67$ & 4,233 & 251.26 & 3,982 \\
\hline & & & & $01 / 07 / 69$ & 4,233 & 223.75 & 4,009 \\
\hline & & & & $01 / 06 / 70$ & 4,233 & 225.83 & 4,007 \\
\hline & & & & $01 / 05 / 71$ & 4,233 & 231.41 & 4,002 \\
\hline & & & & $01 / 05 / 72$ & 4,233 & 234.02 & 3,999 \\
\hline & & & & $01 / 04 / 73$ & 4,233 & 235.68 & 3,997 \\
\hline & & & & $01 / 04 / 74$ & 4,233 & 234.88 & 3,998 \\
\hline & & & & $01 / 04 / 75$ & 4,233 & 237.92 & 3,995 \\
\hline & & & & $01 / 06 / 76$ & 4,233 & 238.99 & 3,994 \\
\hline & & & & 01/06/77 & 4,233 & 242.06 & 3,991 \\
\hline & & & & $01 / 05 / 78$ & 4,233 & 244.81 & 3,988 \\
\hline & & & & $01 / 05 / 79$ & 4,233 & 247.34 & 3,986 \\
\hline & & & & $01 / 07 / 80$ & 4,233 & 252.09 & 3,981 \\
\hline & & & & $01 / 11 / 82$ & 4,233 & 257.05 & 3,976 \\
\hline & & & & $01 / 10 / 83$ & 4,233 & 259.30 & 3,974 \\
\hline & & & & $01 / 19 / 84$ & 4,233 & 261.94 & 3,971 \\
\hline & & & & $01 / 14 / 85$ & 4,233 & 263.37 & 3,970 \\
\hline & & & & $01 / 12 / 87$ & 4,233 & 263.37 & 3,970 \\
\hline & & & & $01 / 13 / 88$ & 4,233 & 263.40 & 3,970 \\
\hline
\end{tabular}


Table I-2. Altitudes of water levels in selected wells at Cannon Air Force Base and the surrounding area.-Continued [Monitoring well, Cannon Air Force Base monitoring well; Primary use of water: I, irrigation; O, observation; S, stock watering; U, unused; Z, other; W, withdrawal; ---, not recorded]

\begin{tabular}{|c|c|c|c|c|c|c|c|}
\hline $\begin{array}{l}\text { Map } \\
\text { identifier } \\
\text { (fig. I-1) }\end{array}$ & $\begin{array}{l}\text { U.S. Geological Survey } \\
\text { identifier }\end{array}$ & Township and range & $\begin{array}{c}\text { Primary } \\
\text { use of } \\
\text { water }\end{array}$ & $\begin{array}{c}\text { Water- } \\
\text { level } \\
\text { date }\end{array}$ & $\begin{array}{l}\text { Altitude } \\
\text { of land } \\
\text { surface } \\
\text { (feet above } \\
\text { NAVD 88) }\end{array}$ & $\begin{array}{c}\text { Water } \\
\text { level } \\
\text { (feet } \\
\text { below } \\
\text { land } \\
\text { surface) }\end{array}$ & $\begin{array}{c}\text { Altitude } \\
\text { of water } \\
\text { level } \\
\text { (feet above } \\
\text { NAVD 88) }\end{array}$ \\
\hline & & & & $01 / 04 / 90$ & 4,233 & 276.42 & 3,957 \\
\hline & & & & $01 / 05 / 91$ & 4,233 & 268.91 & 3,964 \\
\hline & & & & $01 / 05 / 93$ & 4,233 & 274.08 & 3,959 \\
\hline & & & & $01 / 05 / 94$ & 4,233 & 275.58 & 3,957 \\
\hline & & & & $01 / 04 / 95$ & 4,233 & 278.65 & 3,954 \\
\hline & & & & $01 / 11 / 96$ & 4,233 & 283.90 & 3,949 \\
\hline & & & & $01 / 14 / 97$ & 4,233 & 288.21 & 3,945 \\
\hline & & & & $01 / 07 / 98$ & 4,233 & 290.55 & 3,942 \\
\hline & & & & $03 / 05 / 04$ & 4,233 & 300.08 & 3,933 \\
\hline \multirow[t]{23}{*}{41} & 342126103164501 & 02N.35E.33.12111 & I & $01 / 05 / 75$ & 4,256 & 253.72 & 4,002 \\
\hline & & & & $01 / 06 / 76$ & 4,256 & 254.55 & 4,001 \\
\hline & & & & $01 / 06 / 77$ & 4,256 & 257.59 & 3,998 \\
\hline & & & & $01 / 05 / 78$ & 4,256 & 260.82 & 3,995 \\
\hline & & & & $01 / 05 / 79$ & 4,256 & 260.46 & 3,996 \\
\hline & & & & $01 / 07 / 80$ & 4,256 & 261.77 & 3,994 \\
\hline & & & & $01 / 10 / 81$ & 4,256 & 266.45 & 3,990 \\
\hline & & & & $01 / 11 / 82$ & 4,256 & 267.30 & 3,989 \\
\hline & & & & $01 / 10 / 83$ & 4,256 & 268.47 & 3,988 \\
\hline & & & & $01 / 18 / 84$ & 4,256 & 268.73 & 3,987 \\
\hline & & & & $01 / 13 / 85$ & 4,256 & 269.39 & 3,987 \\
\hline & & & & $01 / 13 / 86$ & 4,256 & 271.63 & 3,984 \\
\hline & & & & $01 / 12 / 87$ & 4,256 & 272.32 & 3,984 \\
\hline & & & & $01 / 12 / 88$ & 4,256 & 272.95 & 3,983 \\
\hline & & & & $01 / 04 / 90$ & 4,256 & 276.14 & 3,980 \\
\hline & & & & $01 / 05 / 91$ & 4,256 & 276.63 & 3,979 \\
\hline & & & & $01 / 02 / 92$ & 4,256 & 278.72 & 3,977 \\
\hline & & & & $01 / 05 / 93$ & 4,256 & 281.52 & 3,974 \\
\hline & & & & $01 / 05 / 94$ & 4,256 & 284.70 & 3,971 \\
\hline & & & & $01 / 04 / 95$ & 4,256 & 289.31 & 3,967 \\
\hline & & & & $01 / 11 / 96$ & 4,256 & 293.17 & 3,963 \\
\hline & & & & $01 / 14 / 97$ & 4,256 & 296.21 & 3,960 \\
\hline & & & & $01 / 06 / 98$ & 4,256 & 299.50 & 3,957 \\
\hline \multirow[t]{4}{*}{42} & 342127103185501 & 02N.35E.31.11221 & I & $01 / 16 / 67$ & 4,263 & 234.80 & 4,028 \\
\hline & & & & $01 / 11 / 72$ & 4,263 & 242.02 & 4,021 \\
\hline & & & & $01 / 11 / 77$ & 4,263 & 249.59 & 4,013 \\
\hline & & & & $02 / 09 / 82$ & 4,263 & 258.32 & 4,005 \\
\hline 43 & 342130103161501 & 02N.35E.33.22313 & 1 & $02 / 10 / 82$ & 4,255 & 268.45 & 3,987 \\
\hline \multirow[t]{2}{*}{44} & 342135103211401 & 02N.34E.27.44422 & W & $02 / 06 / 67$ & 4,289 & 227.97 & 4,061 \\
\hline & & & & $01 / 11 / 72$ & 4,289 & 231.39 & 4,058 \\
\hline \multirow[t]{2}{*}{45} & 342135103211402 & 02N.34E.27.444224 & W & $01 / 05 / 77$ & 4,289 & 233.95 & 4,055 \\
\hline & & & & $02 / 12 / 82$ & 4,289 & 240.83 & 4,048 \\
\hline
\end{tabular}


Table I-2. Altitudes of water levels in selected wells at Cannon Air Force Base and the surrounding area.-Continued [Monitoring well, Cannon Air Force Base monitoring well; Primary use of water: I, irrigation; O, observation; S, stock watering; U, unused; Z, other; W, withdrawal; ---, not recorded].

\begin{tabular}{|c|c|c|c|c|c|c|c|}
\hline $\begin{array}{c}\text { Map } \\
\text { identifier } \\
\text { (fig. I-1) }\end{array}$ & $\begin{array}{c}\text { U.S. Geological Survey } \\
\text { identifier }\end{array}$ & Township and range & $\begin{array}{c}\text { Primary } \\
\text { use of } \\
\text { water }\end{array}$ & $\begin{array}{c}\text { Water- } \\
\text { level } \\
\text { date }\end{array}$ & $\begin{array}{c}\text { Altitude } \\
\text { of land } \\
\text { surface } \\
\text { (feet above } \\
\text { NAVD 88) }\end{array}$ & $\begin{array}{c}\text { Water } \\
\text { level } \\
\text { (feet } \\
\text { below } \\
\text { land } \\
\text { surface) }\end{array}$ & $\begin{array}{c}\text { Altitude } \\
\text { of water } \\
\text { level } \\
\text { (feet above } \\
\text { NAVD 88) }\end{array}$ \\
\hline & & & & 03/06/85 & 4,289 & 242.90 & 4,046 \\
\hline & & & & $02 / 06 / 87$ & 4,289 & 244.19 & 4,045 \\
\hline \multirow[t]{2}{*}{46} & 342140103154401 & 02N.35E.27.34333 & 1 & 01/28/82 & 4,255 & 271.15 & 3,984 \\
\hline & & & & $01 / 15 / 87$ & 4,255 & 276.84 & 3,978 \\
\hline \multirow[t]{38}{*}{47} & 342140103190501 & 02N.34E.36.222221 & I & $02 / 10 / 54$ & 4,262 & 214.14 & 4,048 \\
\hline & & & & $01 / 05 / 56$ & 4,262 & 217.47 & 4,045 \\
\hline & & & & $01 / 11 / 57$ & 4,262 & 218.14 & 4,044 \\
\hline & & & & $01 / 13 / 58$ & 4,262 & 217.13 & 4,045 \\
\hline & & & & $01 / 12 / 59$ & 4,262 & 216.84 & 4,045 \\
\hline & & & & $01 / 15 / 60$ & 4,262 & 216.70 & 4,045 \\
\hline & & & & $03 / 06 / 62$ & 4,262 & 216.16 & 4,046 \\
\hline & & & & $01 / 22 / 63$ & 4,262 & 218.34 & 4,044 \\
\hline & & & & $01 / 10 / 64$ & 4,262 & 219.94 & 4,042 \\
\hline & & & & $02 / 17 / 65$ & 4,262 & 227.71 & 4,034 \\
\hline & & & & $01 / 05 / 67$ & 4,262 & 227.15 & 4,035 \\
\hline & & & & $01 / 23 / 67$ & 4,262 & 227.02 & 4,035 \\
\hline & & & & $01 / 11 / 68$ & 4,262 & 231.04 & 4,031 \\
\hline & & & & $01 / 07 / 69$ & 4,262 & 233.26 & 4,029 \\
\hline & & & & $01 / 06 / 70$ & 4,262 & 234.62 & 4,027 \\
\hline & & & & $01 / 05 / 72$ & 4,262 & 239.06 & 4,023 \\
\hline & & & & $01 / 04 / 73$ & 4,262 & 239.14 & 4,023 \\
\hline & & & & $01 / 03 / 74$ & 4,262 & 245.73 & 4,016 \\
\hline & & & & $01 / 04 / 75$ & 4,262 & 243.22 & 4,019 \\
\hline & & & & $01 / 06 / 76$ & 4,262 & 247.96 & 4,014 \\
\hline & & & & $01 / 06 / 77$ & 4,262 & 246.23 & 4,016 \\
\hline & & & & $01 / 05 / 78$ & 4,262 & 250.07 & 4,012 \\
\hline & & & & $01 / 05 / 79$ & 4,262 & 249.31 & 4,013 \\
\hline & & & & 01/07/80 & 4,262 & 252.78 & 4,009 \\
\hline & & & & $01 / 11 / 82$ & 4,262 & 255.76 & 4,006 \\
\hline & & & & $01 / 10 / 83$ & 4,262 & 256.52 & 4,005 \\
\hline & & & & $01 / 18 / 84$ & 4,262 & 259.66 & 4,002 \\
\hline & & & & $01 / 13 / 85$ & 4,262 & 256.96 & 4,005 \\
\hline & & & & $01 / 13 / 86$ & 4,262 & 260.20 & 4,002 \\
\hline & & & & $01 / 12 / 87$ & 4,262 & 258.94 & 4,003 \\
\hline & & & & $01 / 12 / 88$ & 4,262 & 255.07 & 4,007 \\
\hline & & & & $01 / 03 / 90$ & 4,262 & 258.12 & 4,004 \\
\hline & & & & $01 / 04 / 91$ & 4,262 & 258.41 & 4,004 \\
\hline & & & & $01 / 02 / 92$ & 4,262 & 256.75 & 4,005 \\
\hline & & & & $01 / 05 / 93$ & 4,262 & 257.95 & 4,004 \\
\hline & & & & $01 / 05 / 94$ & 4,262 & 259.47 & 4,003 \\
\hline & & & & $01 / 04 / 95$ & 4,262 & 262.80 & 3,999 \\
\hline & & & & $01 / 17 / 97$ & 4,262 & 266.11 & 3,996 \\
\hline
\end{tabular}


Table I-2. Altitudes of water levels in selected wells at Cannon Air Force Base and the surrounding area.—Continued [Monitoring well, Cannon Air Force Base monitoring well; Primary use of water: I, irrigation; O, observation; S, stock watering; U, unused; Z, other; W, withdrawal; ---, not recorded]

\begin{tabular}{|c|c|c|c|c|c|c|c|}
\hline $\begin{array}{c}\text { Map } \\
\text { identifier } \\
\text { (fig. I-1) }\end{array}$ & $\begin{array}{l}\text { U.S. Geological Survey } \\
\text { identifier }\end{array}$ & Township and range & $\begin{array}{c}\text { Primary } \\
\text { use of } \\
\text { water }\end{array}$ & $\begin{array}{c}\text { Water- } \\
\text { level } \\
\text { date }\end{array}$ & $\begin{array}{c}\text { Altitude } \\
\text { of land } \\
\text { surface } \\
\text { (feet above } \\
\text { NAVD 88) }\end{array}$ & $\begin{array}{c}\text { Water } \\
\text { level } \\
\text { (feet } \\
\text { below } \\
\text { land } \\
\text { surface) }\end{array}$ & $\begin{array}{c}\text { Altitude } \\
\text { of water } \\
\text { level } \\
\text { (feet above } \\
\text { NAVD 88) }\end{array}$ \\
\hline & & & & $01 / 06 / 98$ & 4,262 & 268.99 & 3,993 \\
\hline & & & & $03 / 04 / 04$ & 4,262 & 276.02 & 3,986 \\
\hline \multirow[t]{5}{*}{48} & 342142103221201 & 02N.34E.27.333432 & 1 & $02 / 17 / 82$ & 4,294 & 239.82 & 4,054 \\
\hline & & & & $02 / 05 / 87$ & 4,294 & 242.24 & 4,052 \\
\hline & & & & $03 / 13 / 92$ & 4,294 & 242.84 & 4,051 \\
\hline & & & & $03 / 06 / 97$ & 4,294 & 242.59 & 4,051 \\
\hline & & & & $03 / 14 / 02$ & 4,294 & 239.39 & 4,055 \\
\hline \multirow[t]{4}{*}{49} & 342145103232501 & 02N.34E.29.42430 & U & $03 / 08 / 62$ & 4,289 & 219.09 & 4,070 \\
\hline & & & & $01 / 26 / 67$ & 4,289 & 213.68 & 4,075 \\
\hline & & & & $01 / 12 / 72$ & 4,289 & 217.15 & 4,072 \\
\hline & & & & $01 / 05 / 77$ & 4,289 & 219.90 & 4,069 \\
\hline \multirow[t]{2}{*}{50} & 342147103201501 & 02N.34E.26.44421 & W & $02 / 17 / 82$ & 4,261 & 229.07 & 4,032 \\
\hline & & & & $02 / 10 / 87$ & 4,261 & 233.98 & 4,027 \\
\hline \multirow[t]{2}{*}{51} & 342153103181401 & 02N.35E.30.42344 & 1 & $02 / 10 / 82$ & 4,262 & 259.91 & 4,002 \\
\hline & & & & $01 / 15 / 87$ & 4,262 & 264.13 & 3,998 \\
\hline 52 & 342155103171801 & 02N.35E.29.44111 & 1 & $02 / 12 / 94$ & 4,260 & 250.00 & 4,010 \\
\hline \multirow[t]{14}{*}{53} & 342156103180801 & 02N.35E.30.4244 & 0 & $04 / 06 / 98$ & $4,263.72$ & 289.19 & $3,974.53$ \\
\hline & & (Monitoring well C) & & $03 / 02 / 99$ & $4,263.72$ & 293.85 & $3,969.87$ \\
\hline & & & & $08 / 29 / 99$ & $4,263.72$ & 295.35 & $3,968.37$ \\
\hline & & & & $03 / 01 / 00$ & $4,263.72$ & 292.13 & $3,971.59$ \\
\hline & & & & $08 / 10 / 00$ & $4,263.72$ & 299.64 & $3,964.08$ \\
\hline & & & & 03/23/01 & $4,263.72$ & 296.07 & $3,967.65$ \\
\hline & & & & $08 / 22 / 01$ & $4,263.72$ & 300.93 & $3,962.79$ \\
\hline & & & & 03/13/02 & $4,263.72$ & 296.42 & $3,967.30$ \\
\hline & & & & $08 / 13 / 02$ & $4,263.72$ & 305.61 & $3,958.11$ \\
\hline & & & & 03/20/03 & $4,263.72$ & 302.11 & $3,961.61$ \\
\hline & & & & $08 / 20 / 03$ & $4,263.72$ & 307.36 & $3,956.36$ \\
\hline & & & & $06 / 15 / 04$ & $4,263.72$ & 308.30 & $3,955.42$ \\
\hline & & & & $10 / 21 / 04$ & $4,263.72$ & 306.04 & $3,957.68$ \\
\hline & & & & 01/10/05 & $4,263.72$ & 305.25 & $3,958.47$ \\
\hline 54 & 342156103180802 & $\begin{array}{c}\text { 02N.35E.30.424A } \\
\text { (Monitoring well J) }\end{array}$ & 0 & --- & $4,261.11$ & --- & --- \\
\hline \multirow[t]{10}{*}{55} & 342157103181101 & 02N.35E.30.424E & 0 & $03 / 02 / 99$ & $4,260.72$ & 289.12 & $3,971.60$ \\
\hline & & (Monitoring well S) & & $08 / 29 / 99$ & $4,260.72$ & 290.92 & $3,969.80$ \\
\hline & & & & $02 / 29 / 00$ & $4,260.72$ & 289.71 & $3,971.01$ \\
\hline & & & & $08 / 10 / 00$ & $4,260.72$ & 294.23 & $3,966.49$ \\
\hline & & & & 03/29/01 & $4,260.72$ & 293.80 & $3,966.92$ \\
\hline & & & & $08 / 21 / 01$ & $4,260.72$ & 295.66 & $3,965.06$ \\
\hline & & & & 03/13/02 & $4,260.72$ & 294.37 & $3,966.35$ \\
\hline & & & & $08 / 15 / 02$ & $4,260.72$ & 299.69 & $3,961.03$ \\
\hline & & & & 03/19/03 & $4,260.72$ & 297.13 & $3,963.59$ \\
\hline & & & & 08/19/03 & $4,260.72$ & 301.98 & $3,958.74$ \\
\hline
\end{tabular}


Table I-2. Altitudes of water levels in selected wells at Cannon Air Force Base and the surrounding area.-Continued [Monitoring well, Cannon Air Force Base monitoring well; Primary use of water: I, irrigation; O, observation; S, stock watering; U, unused; Z, other; W, withdrawal; ---, not recorded]

\begin{tabular}{|c|c|c|c|c|c|c|c|}
\hline $\begin{array}{c}\text { Map } \\
\text { identifier } \\
\text { (fig. I-1) }\end{array}$ & $\begin{array}{l}\text { U.S. Geological Survey } \\
\text { identifier }\end{array}$ & Township and range & $\begin{array}{c}\text { Primary } \\
\text { use of } \\
\text { water }\end{array}$ & $\begin{array}{c}\text { Water- } \\
\text { level } \\
\text { date }\end{array}$ & $\begin{array}{c}\text { Altitude } \\
\text { of land } \\
\text { surface } \\
\text { (feet above } \\
\text { NAVD 88) }\end{array}$ & $\begin{array}{c}\text { Water } \\
\text { level } \\
\text { (feet } \\
\text { below } \\
\text { land } \\
\text { surface) }\end{array}$ & $\begin{array}{c}\text { Altitude } \\
\text { of water } \\
\text { level } \\
\text { (feet above } \\
\text { NAVD 88) }\end{array}$ \\
\hline & & & & $02 / 27 / 04$ & $4,260.72$ & 299.83 & $3,960.89$ \\
\hline & & & & $06 / 14 / 04$ & $4,260.72$ & 303.62 & $3,957.10$ \\
\hline & & & & $08 / 12 / 04$ & $4,260.72$ & 304.24 & $3,956.48$ \\
\hline & & & & $10 / 21 / 04$ & $4,260.72$ & 304.42 & $3,956.30$ \\
\hline & & & & 01/10/05 & $4,260.72$ & 303.68 & $3,957.04$ \\
\hline \multirow[t]{13}{*}{56} & 342157103181701 & 02N.35E.30.423 & 0 & $03 / 02 / 99$ & $4,261.94$ & 287.22 & $3,974.72$ \\
\hline & & (Monitoring well D) & & 08/29/99 & $4,261.94$ & 289.08 & $3,972.86$ \\
\hline & & & & 03/01/00 & $4,261.94$ & 288.23 & $3,973.71$ \\
\hline & & & & $08 / 10 / 00$ & $4,261.94$ & 292.44 & $3,969.50$ \\
\hline & & & & $03 / 21 / 01$ & $4,261.94$ & 291.73 & $3,970.21$ \\
\hline & & & & $08 / 22 / 01$ & $4,261.94$ & 293.99 & $3,967.95$ \\
\hline & & & & $03 / 12 / 02$ & $4,261.94$ & 292.44 & $3,969.50$ \\
\hline & & & & 08/13/02 & $4,261.94$ & 298.24 & $3,963.70$ \\
\hline & & & & 03/20/03 & $4,261.94$ & 297.14 & $3,964.80$ \\
\hline & & & & 08/20/03 & $4,261.94$ & 300.05 & $3,961.89$ \\
\hline & & & & 06/16/04 & $4,261.94$ & 301.38 & $3,960.56$ \\
\hline & & & & $10 / 21 / 04$ & $4,261.94$ & 301.53 & $3,960.41$ \\
\hline & & & & $01 / 10 / 05$ & $4,261.94$ & 300.68 & $3,961.26$ \\
\hline \multirow[t]{15}{*}{57} & 342158103180601 & 02N.35E.30.4242D & 0 & $02 / 21 / 94$ & $4,261.57$ & 270.95 & $3,990.62$ \\
\hline & & (Monitoring well I) & & 08/09/94 & $4,261.57$ & 273.32 & $3,988.25$ \\
\hline & & & & 02/23/95 & $4,261.57$ & 275.17 & $3,986.40$ \\
\hline & & & & $08 / 22 / 95$ & $4,261.57$ & 276.42 & $3,985.15$ \\
\hline & & & & $02 / 29 / 96$ & $4,261.57$ & 278.18 & $3,983.39$ \\
\hline & & & & 08/19/96 & $4,261.57$ & 280.59 & $3,980.98$ \\
\hline & & & & $12 / 17 / 96$ & $4,261.57$ & 280.51 & $3,981.06$ \\
\hline & & & & 03/05/97 & $4,261.57$ & 281.41 & $3,980.16$ \\
\hline & & & & $05 / 28 / 97$ & $4,261.57$ & 281.65 & $3,979.92$ \\
\hline & & & & 08/18/97 & $4,261.57$ & 283.13 & $3,978.44$ \\
\hline & & & & 04/06/98 & $4,261.57$ & 284.81 & $3,976.76$ \\
\hline & & & & 08/12/98 & $4,261.57$ & 288.20 & $3,973.37$ \\
\hline & & & & $03 / 02 / 99$ & $4,261.57$ & 289.17 & $3,972.40$ \\
\hline & & & & 08/29/99 & $4,261.57$ & 291.01 & $3,970.56$ \\
\hline & & & & $02 / 28 / 00$ & $4,261.57$ & 290.23 & $3,971.34$ \\
\hline \multirow[t]{9}{*}{58} & 342200103180901 & 02N.35E.30.424F & 0 & $03 / 02 / 99$ & $4,260.82$ & 288.70 & $3,972.12$ \\
\hline & & (Monitoring well T) & & $08 / 29 / 99$ & $4,260.82$ & 289.84 & $3,970.98$ \\
\hline & & & & $02 / 29 / 00$ & $4,260.82$ & 289.29 & $3,971.53$ \\
\hline & & & & 08/10/00 & $4,260.82$ & 292.90 & $3,967.92$ \\
\hline & & & & 03/20/01 & $4,260.82$ & 292.93 & $3,967.89$ \\
\hline & & & & $08 / 21 / 01$ & $4,260.82$ & 294.47 & $3,966.35$ \\
\hline & & & & 03/13/02 & $4,260.82$ & 293.84 & $3,966.98$ \\
\hline & & & & 08/15/02 & $4,260.82$ & 297.99 & $3,962.83$ \\
\hline & & & & 03/19/03 & $4,260.82$ & 297.40 & $3,963.42$ \\
\hline
\end{tabular}


Table I-2. Altitudes of water levels in selected wells at Cannon Air Force Base and the surrounding area.—Continued [Monitoring well, Cannon Air Force Base monitoring well; Primary use of water: I, irrigation; O, observation; S, stock watering; U, unused; Z, other; W, withdrawal; ---, not recorded]

\begin{tabular}{|c|c|c|c|c|c|c|c|}
\hline $\begin{array}{c}\text { Map } \\
\text { identifier } \\
\text { (fig. I-1) }\end{array}$ & $\begin{array}{l}\text { U.S. Geological Survey } \\
\text { identifier }\end{array}$ & Township and range & $\begin{array}{c}\text { Primary } \\
\text { use of } \\
\text { water }\end{array}$ & $\begin{array}{c}\text { Water- } \\
\text { level } \\
\text { date }\end{array}$ & $\begin{array}{c}\text { Altitude } \\
\text { of land } \\
\text { surface } \\
\text { (feet above } \\
\text { NAVD 88) }\end{array}$ & $\begin{array}{c}\text { Water } \\
\text { level } \\
\text { (feet } \\
\text { below } \\
\text { land } \\
\text { surface) }\end{array}$ & $\begin{array}{c}\text { Altitude } \\
\text { of water } \\
\text { level } \\
\text { (feet above } \\
\text { NAVD 88) }\end{array}$ \\
\hline & & & & 08/19/03 & $4,260.82$ & 300.51 & $3,960.31$ \\
\hline & & & & $06 / 15 / 04$ & $4,260.82$ & 302.41 & $3,958.41$ \\
\hline & & & & $08 / 12 / 04$ & $4,260.82$ & 302.99 & $3,957.83$ \\
\hline & & & & $10 / 21 / 04$ & $4,260.82$ & 303.50 & $3,957.32$ \\
\hline & & & & 01/10/05 & $4,260.82$ & 302.89 & $3,957.93$ \\
\hline \multirow[t]{11}{*}{59} & 342200103181001 & 02N.35E.30.4242C & 0 & $02 / 21 / 94$ & $4,261.28$ & 272.67 & $3,988.61$ \\
\hline & & (Monitoring well M) & & 08/09/94 & $4,261.28$ & 272.97 & $3,988.31$ \\
\hline & & & & 02/23/95 & $4,261.28$ & 274.72 & $3,986.56$ \\
\hline & & & & $08 / 22 / 95$ & $4,261.28$ & 276.79 & $3,984.49$ \\
\hline & & & & $02 / 29 / 96$ & $4,261.28$ & 277.85 & $3,983.43$ \\
\hline & & & & $08 / 19 / 96$ & $4,261.28$ & 280.37 & $3,980.91$ \\
\hline & & & & $12 / 17 / 96$ & $4,261.28$ & 280.67 & $3,980.61$ \\
\hline & & & & $03 / 04 / 97$ & $4,261.28$ & 280.69 & $3,980.59$ \\
\hline & & & & $05 / 27 / 97$ & $4,261.28$ & 281.29 & $3,979.99$ \\
\hline & & & & 08/19/97 & $4,261.28$ & 282.71 & $3,978.57$ \\
\hline & & & & 08/06/98 & $4,261.28$ & 283.07 & $3,978.21$ \\
\hline \multirow[t]{10}{*}{60} & 342201103180901 & 02N.35E.30.4242B & 0 & $02 / 21 / 94$ & $4,261.38$ & 271.05 & $3,990.33$ \\
\hline & & (Monitoring well L) & & 08/09/94 & $4,261.38$ & 273.42 & $3,987.96$ \\
\hline & & & & 02/23/95 & $4,261.38$ & 275.23 & $3,986.15$ \\
\hline & & & & $08 / 22 / 95$ & $4,261.38$ & 276.47 & $3,984.91$ \\
\hline & & & & $02 / 28 / 96$ & $4,261.38$ & 278.23 & $3,983.15$ \\
\hline & & & & 08/19/96 & $4,261.38$ & 280.46 & $3,980.92$ \\
\hline & & & & $12 / 16 / 96$ & $4,261.38$ & 280.50 & $3,980.88$ \\
\hline & & & & 03/05/97 & $4,261.38$ & 281.37 & $3,980.01$ \\
\hline & & & & $05 / 28 / 97$ & $4,261.38$ & 281.64 & $3,979.74$ \\
\hline & & & & 08/19/97 & $4,261.38$ & 283.08 & $3,978.30$ \\
\hline \multirow[t]{16}{*}{61} & 342203103181001 & 02N.35E.30.4242A & 0 & $02 / 21 / 94$ & $4,262.10$ & 270.29 & $3,991.81$ \\
\hline & & (Monitoring well B) & & $02 / 22 / 95$ & $4,262.10$ & 274.06 & $3,988.04$ \\
\hline & & & & $08 / 23 / 95$ & $4,262.10$ & 275.25 & $3,986.85$ \\
\hline & & & & 03/04/97 & $4,262.10$ & 281.32 & $3,980.78$ \\
\hline & & & & $05 / 29 / 97$ & $4,262.10$ & 281.54 & $3,980.56$ \\
\hline & & & & $07 / 23 / 97$ & $4,262.10$ & 282.59 & $3,979.51$ \\
\hline & & & & $08 / 21 / 97$ & $4,262.10$ & 283.13 & $3,978.97$ \\
\hline & & & & $10 / 29 / 97$ & $4,262.10$ & 284.55 & $3,977.55$ \\
\hline & & & & 01/05/98 & $4,262.10$ & 283.95 & $3,978.15$ \\
\hline & & & & 04/06/98 & $4,262.10$ & 284.85 & $3,977.25$ \\
\hline & & & & 08/12/98 & $4,262.10$ & 288.03 & $3,974.07$ \\
\hline & & & & $12 / 07 / 98$ & $4,262.10$ & 289.14 & $3,972.96$ \\
\hline & & & & 03/01/99 & $4,262.10$ & 288.45 & $3,973.65$ \\
\hline & & & & 03/03/99 & $4,262.10$ & 285.65 & $3,976.45$ \\
\hline & & & & 08/29/99 & $4,262.10$ & 289.30 & $3,972.80$ \\
\hline & & & & 09/22/99 & $4,262.10$ & 290.56 & $3,971.54$ \\
\hline
\end{tabular}


Table I-2. Altitudes of water levels in selected wells at Cannon Air Force Base and the surrounding area.-Continued [Monitoring well, Cannon Air Force Base monitoring well; Primary use of water: I, irrigation; O, observation; S, stock watering; U, unused; Z, other; W, withdrawal; ---, not recorded]

\begin{tabular}{|c|c|c|c|c|c|c|c|}
\hline $\begin{array}{c}\text { Map } \\
\text { identifier } \\
\text { (fig. I-1) }\end{array}$ & $\begin{array}{c}\text { U.S. Geological Survey } \\
\text { identifier }\end{array}$ & Township and range & $\begin{array}{c}\text { Primary } \\
\text { use of } \\
\text { water }\end{array}$ & $\begin{array}{c}\text { Water- } \\
\text { level } \\
\text { date }\end{array}$ & $\begin{array}{c}\text { Altitude } \\
\text { of land } \\
\text { surface } \\
\text { (feet above } \\
\text { NAVD 88) }\end{array}$ & $\begin{array}{c}\text { Water } \\
\text { level } \\
\text { (feet } \\
\text { below } \\
\text { land } \\
\text { surface) }\end{array}$ & $\begin{array}{c}\text { Altitude } \\
\text { of water } \\
\text { level } \\
\text { (feet above } \\
\text { NAVD 88) }\end{array}$ \\
\hline & & & & 03/01/00 & $4,262.10$ & 290.25 & $3,971.85$ \\
\hline & & & & $08 / 09 / 00$ & $4,262.10$ & 293.18 & $3,968.92$ \\
\hline & & & & $09 / 22 / 00$ & $4,262.10$ & 293.40 & $3,968.70$ \\
\hline & & & & $01 / 31 / 01$ & $4,262.10$ & 291.87 & $3,970.23$ \\
\hline & & & & $03 / 21 / 01$ & $4,262.10$ & 293.31 & $3,968.79$ \\
\hline & & & & $07 / 17 / 01$ & $4,262.10$ & 294.62 & $3,967.48$ \\
\hline & & & & $08 / 21 / 01$ & $4,262.10$ & 292.33 & $3,969.77$ \\
\hline & & & & $03 / 13 / 02$ & $4,262.10$ & 294.35 & $3,967.75$ \\
\hline & & & & $08 / 15 / 02$ & $4,262.10$ & 298.10 & $3,964.00$ \\
\hline & & & & 03/18/03 & $4,262.10$ & 297.95 & $3,964.15$ \\
\hline & & & & $08 / 20 / 03$ & $4,262.10$ & 300.65 & $3,961.45$ \\
\hline & & & & $11 / 04 / 03$ & $4,262.10$ & 299.47 & $3,962.63$ \\
\hline & & & & $12 / 15 / 03$ & $4,262.10$ & 300.91 & $3,961.19$ \\
\hline & & & & $02 / 27 / 04$ & $4,262.10$ & 298.82 & $3,963.28$ \\
\hline & & & & $05 / 26 / 04$ & $4,262.10$ & 301.76 & $3,960.34$ \\
\hline & & & & 06/16/04 & $4,262.10$ & 302.23 & $3,959.87$ \\
\hline & & & & $08 / 12 / 04$ & $4,262.10$ & 302.90 & $3,959.20$ \\
\hline & & & & $10 / 21 / 04$ & $4,262.10$ & 303.45 & $3,958.65$ \\
\hline & & & & $01 / 10 / 05$ & $4,262.10$ & 302.93 & $3,959.17$ \\
\hline \multirow[t]{14}{*}{62} & 342205103181001 & 02N.35E.30.422 & 0 & $03 / 02 / 99$ & $4,262.27$ & 288.67 & $3,973.60$ \\
\hline & & (Monitoring well U) & & $08 / 29 / 99$ & $4,262.27$ & 289.55 & $3,972.72$ \\
\hline & & & & $02 / 29 / 00$ & $4,262.27$ & 289.12 & $3,973.15$ \\
\hline & & & & $08 / 10 / 00$ & $4,262.27$ & 292.19 & $3,970.08$ \\
\hline & & & & $03 / 20 / 01$ & $4,262.27$ & 292.51 & $3,969.76$ \\
\hline & & & & $08 / 21 / 01$ & $4,262.27$ & 293.74 & $3,968.53$ \\
\hline & & & & 03/13/02 & $4,262.27$ & 293.68 & $3,968.59$ \\
\hline & & & & $08 / 15 / 02$ & $4,262.27$ & 296.97 & $3,965.30$ \\
\hline & & & & 03/19/03 & $4,262.27$ & 297.34 & $3,964.93$ \\
\hline & & & & 08/19/03 & $4,262.27$ & 299.54 & $3,962.73$ \\
\hline & & & & $06 / 16 / 04$ & $4,262.27$ & 301.50 & $3,960.77$ \\
\hline & & & & $08 / 12 / 04$ & $4,262.27$ & 302.10 & $3,960.17$ \\
\hline & & & & $10 / 21 / 04$ & $4,262.27$ & 302.80 & $3,959.47$ \\
\hline & & & & $01 / 10 / 05$ & $4,262.27$ & 302.35 & $3,959.92$ \\
\hline \multirow[t]{2}{*}{63} & 342206103192501 & 02N.34E.25.412222 & I & $02 / 11 / 82$ & 4,266 & 251.60 & 4,014 \\
\hline & & & & $02 / 06 / 87$ & 4,266 & 255.15 & 4,011 \\
\hline 64 & 342212103170401 & 02N.35E.29.242443 & I & $01 / 27 / 87$ & 4,261 & 266.73 & 3,994 \\
\hline \multirow[t]{6}{*}{65} & 342218103182601 & 02N.35E.30.23213 & 0 & $02 / 21 / 94$ & $4,263.83$ & 266.82 & $3,997.01$ \\
\hline & & (Monitoring well A) & & $08 / 09 / 94$ & $4,263.83$ & 268.31 & $3,995.52$ \\
\hline & & & & $02 / 22 / 95$ & $4,263.83$ & 269.76 & $3,994.07$ \\
\hline & & & & $08 / 21 / 95$ & $4,263.83$ & 271.33 & $3,992.50$ \\
\hline & & & & $02 / 28 / 96$ & $4,263.83$ & 273.17 & $3,990.66$ \\
\hline & & & & $08 / 22 / 01$ & $4,263.83$ & 285.93 & $3,977.90$ \\
\hline
\end{tabular}


Table I-2. Altitudes of water levels in selected wells at Cannon Air Force Base and the surrounding area.-Continued [Monitoring well, Cannon Air Force Base monitoring well; Primary use of water: I, irrigation; O, observation; S, stock watering; U, unused; Z, other; W, withdrawal; ---, not recorded]

\begin{tabular}{|c|c|c|c|c|c|c|c|}
\hline $\begin{array}{c}\text { Map } \\
\text { identifier } \\
\text { (fig. I-1) }\end{array}$ & $\begin{array}{c}\text { U.S. Geological Survey } \\
\text { identifier }\end{array}$ & Township and range & $\begin{array}{c}\text { Primary } \\
\text { use of } \\
\text { water }\end{array}$ & $\begin{array}{c}\text { Water- } \\
\text { level } \\
\text { date }\end{array}$ & $\begin{array}{c}\text { Altitude } \\
\text { of land } \\
\text { surface } \\
\text { (feet above } \\
\text { NAVD 88) }\end{array}$ & $\begin{array}{c}\text { Water } \\
\text { level } \\
\text { (feet } \\
\text { below } \\
\text { land } \\
\text { surface) }\end{array}$ & $\begin{array}{c}\text { Altitude } \\
\text { of water } \\
\text { level } \\
\text { (feet above } \\
\text { NAVD 88) }\end{array}$ \\
\hline & & & & 03/12/02 & $4,263.83$ & 286.92 & $3,976.91$ \\
\hline & & & & $08 / 20 / 03$ & $4,263.83$ & 290.94 & $3,972.89$ \\
\hline & & & & $11 / 04 / 03$ & $4,263.83$ & 291.41 & $3,972.42$ \\
\hline & & & & $12 / 15 / 03$ & $4,263.83$ & 291.89 & $3,971.94$ \\
\hline & & & & $02 / 27 / 04$ & $4,263.83$ & 290.35 & $3,973.48$ \\
\hline & & & & $05 / 26 / 04$ & $4,263.83$ & 292.59 & $3,971.24$ \\
\hline & & & & $06 / 16 / 04$ & $4,263.83$ & 292.82 & $3,971.01$ \\
\hline & & & & $08 / 12 / 04$ & $4,263.83$ & 293.15 & $3,970.68$ \\
\hline & & & & $10 / 21 / 04$ & $4,263.83$ & 293.73 & $3,970.10$ \\
\hline & & & & $01 / 10 / 05$ & $4,263.83$ & 293.88 & $3,969.95$ \\
\hline \multirow[t]{17}{*}{66} & 342219103183101 & 02N.35E.30.23211 & 0 & $02 / 27 / 96$ & $4,263.50$ & 272.03 & $3,991.47$ \\
\hline & & (Monitoring well 0) & & $11 / 19 / 96$ & $4,263.50$ & 274.27 & $3,989.23$ \\
\hline & & & & $03 / 04 / 97$ & $4,263.50$ & 275.07 & $3,988.43$ \\
\hline & & & & $05 / 27 / 97$ & $4,263.50$ & 275.58 & $3,987.92$ \\
\hline & & & & $08 / 18 / 97$ & $4,263.50$ & 276.17 & $3,987.33$ \\
\hline & & & & $04 / 06 / 98$ & $4,263.50$ & 277.79 & $3,985.71$ \\
\hline & & & & $08 / 12 / 98$ & $4,263.50$ & 280.30 & $3,983.20$ \\
\hline & & & & $03 / 02 / 99$ & $4,263.50$ & 281.45 & $3,982.05$ \\
\hline & & & & $08 / 29 / 99$ & $4,263.50$ & 282.37 & $3,981.13$ \\
\hline & & & & $02 / 28 / 00$ & $4,263.50$ & 282.85 & $3,980.65$ \\
\hline & & & & $08 / 10 / 00$ & $4,263.50$ & 284.17 & $3,979.33$ \\
\hline & & & & $03 / 20 / 01$ & $4,263.50$ & 285.59 & $3,977.91$ \\
\hline & & & & $08 / 22 / 01$ & $4,263.50$ & 286.02 & $3,977.48$ \\
\hline & & & & $03 / 12 / 02$ & $4,263.50$ & 286.99 & $3,976.51$ \\
\hline & & & & $08 / 13 / 02$ & $4,263.50$ & 288.43 & $3,975.07$ \\
\hline & & & & 03/19/03 & $4,263.50$ & 289.89 & $3,973.61$ \\
\hline & & & & 08/19/03 & $4,263.50$ & 290.89 & $3,972.61$ \\
\hline \multirow[t]{5}{*}{67} & 342222103194301 & 02N.34E.25.124 & 0 & $03 / 11 / 04$ & $4,264.76$ & 270.26 & $3,994.50$ \\
\hline & & (Monitoring well X) & & $04 / 20 / 04$ & $4,264.76$ & 270.10 & $3,994.66$ \\
\hline & & & & $06 / 15 / 04$ & $4,264.76$ & 270.71 & $3,994.05$ \\
\hline & & & & $10 / 21 / 04$ & $4,264.76$ & 271.21 & $3,993.55$ \\
\hline & & & & $01 / 10 / 05$ & $4,264.76$ & 270.12 & $3,994.64$ \\
\hline 68 & 342225103173401 & 02N.35E.29.21133 & I & $02 / 11 / 54$ & 4,269 & 222.78 & 4,046 \\
\hline \multirow[t]{2}{*}{69} & 342225103235501 & 02N.34E.29.12421 & I & $02 / 12 / 82$ & 4,308 & 234.79 & 4,073 \\
\hline & & & & $02 / 06 / 87$ & 4,308 & 233.33 & 4,075 \\
\hline \multirow[t]{3}{*}{70} & 342232103211801 & 02N.34E.27.22221 & S & $02 / 26 / 82$ & 4,294 & 255.90 & 4,038 \\
\hline & & & & $02 / 05 / 87$ & 4,294 & 260.32 & 4,034 \\
\hline & & & & 02/10/87 & 4,294 & 260.04 & 4,034 \\
\hline \multirow[t]{2}{*}{71} & 342237103155101 & 02N.35E.22.334111 & I & $01 / 28 / 82$ & 4,244 & 254.23 & 3,990 \\
\hline & & & & $01 / 15 / 87$ & 4,244 & 259.17 & 3,985 \\
\hline 72 & 342240103170201 & 02N.35E.21.331313 & I & $02 / 10 / 82$ & 4,260 & 260.83 & 3,999 \\
\hline
\end{tabular}


Table I-2. Altitudes of water levels in selected wells at Cannon Air Force Base and the surrounding area.-Continued [Monitoring well, Cannon Air Force Base monitoring well; Primary use of water: I, irrigation; O, observation; S, stock watering; U, unused; Z, other; W, withdrawal; ---, not recorded].

\begin{tabular}{|c|c|c|c|c|c|c|c|}
\hline $\begin{array}{c}\text { Map } \\
\text { identifier } \\
\text { (fig. I-1) }\end{array}$ & $\begin{array}{l}\text { U.S. Geological Survey } \\
\text { identifier }\end{array}$ & Township and range & $\begin{array}{l}\text { Primary } \\
\text { use of } \\
\text { water }\end{array}$ & $\begin{array}{c}\text { Water- } \\
\text { level } \\
\text { date }\end{array}$ & $\begin{array}{c}\text { Altitude } \\
\text { of land } \\
\text { surface } \\
\text { (feet above } \\
\text { NAVD 88) }\end{array}$ & $\begin{array}{c}\text { Water } \\
\text { level } \\
\text { (feet } \\
\text { below } \\
\text { land } \\
\text { surface) }\end{array}$ & $\begin{array}{c}\text { Altitude } \\
\text { of water } \\
\text { level } \\
\text { (feet above } \\
\text { NAVD 88) }\end{array}$ \\
\hline \multirow[t]{7}{*}{73} & 342240103175001 & 02N.35E.20.312432 & 1 & 02/10/54 & 4,274 & 223.96 & 4,050 \\
\hline & & & & $02 / 27 / 62$ & 4,274 & 227.92 & 4,046 \\
\hline & & & & $01 / 16 / 67$ & 4,274 & 237.08 & 4,037 \\
\hline & & & & $02 / 16 / 72$ & 4,274 & 248.99 & 4,025 \\
\hline & & & & $01 / 07 / 77$ & 4,274 & 260.62 & 4,013 \\
\hline & & & & $02 / 10 / 82$ & 4,274 & 263.24 & 4,011 \\
\hline & & & & $01 / 15 / 87$ & 4,274 & 268.71 & 4,005 \\
\hline \multirow[t]{3}{*}{74} & 342246103172101 & 02N.35E.20.23434 & 1 & $01 / 12 / 72$ & 4,262 & 242.85 & 4,019 \\
\hline & & & & $01 / 07 / 77$ & 4,262 & 249.56 & 4,012 \\
\hline & & & & $02 / 11 / 82$ & 4,262 & 255.29 & 4,007 \\
\hline \multirow[t]{4}{*}{75} & 342246103204201 & 02N.34E.23.32222 & U & $01 / 27 / 77$ & 4,297 & 308.95 & 3,988 \\
\hline & & & & $02 / 17 / 82$ & 4,297 & 265.64 & 4,031 \\
\hline & & & & 02/06/87 & 4,297 & 270.08 & 4,027 \\
\hline & & & & 03/07/97 & 4,297 & 276.06 & 4,021 \\
\hline 76 & 342258103150501 & 02N.35E.22.24344 & I & $01 / 27 / 82$ & 4,258 & 269.80 & 3,988 \\
\hline \multirow[t]{5}{*}{77} & 342300103175001 & --- & 0 & $02 / 29 / 04$ & $4,270.11$ & 294.97 & $3,975.14$ \\
\hline & & (Monitoring well 0a) & & 05/26/04 & $4,270.11$ & 297.12 & $3,972.99$ \\
\hline & & & & 08/12/04 & $4,270.11$ & 299.88 & $3,970.23$ \\
\hline & & & & $10 / 21 / 04$ & $4,270.11$ & 298.75 & $3,971.36$ \\
\hline & & & & $01 / 10 / 05$ & $4,270.11$ & 297.50 & $3,972.61$ \\
\hline \multirow[t]{2}{*}{78} & 342304103174401 & 02N.35E.20.1432 & 0 & $06 / 27 / 95$ & $4,269.26$ & 281.15 & $3,988.11$ \\
\hline & & (Monitoring well 0) & & $02 / 27 / 96$ & $4,269.26$ & 281.21 & $3,988.05$ \\
\hline \multirow[t]{5}{*}{79} & 342306103142101 & 02N.35E.23.211311 & I & $01 / 20 / 67$ & 4,267 & 260.80 & 4,006 \\
\hline & & & & $01 / 11 / 72$ & 4,267 & 268.46 & 3,999 \\
\hline & & & & $01 / 07 / 77$ & 4,267 & 276.92 & 3,990 \\
\hline & & & & $01 / 26 / 82$ & 4,267 & 281.72 & 3,985 \\
\hline & & & & 01/15/87 & 4,267 & 284.58 & 3,982 \\
\hline \multirow[t]{2}{*}{80} & 342306103221801 & 02N.34E.21.24240 & W & $02 / 12 / 82$ & 4,314 & 267.68 & 4,046 \\
\hline & & & & 02/06/87 & 4,314 & 270.06 & 4,044 \\
\hline \multirow[t]{12}{*}{81} & 342307103181601 & 02N.35E.19.241 & 0 & 09/13/93 & $4,275.98$ & 278.40 & $3,997.58$ \\
\hline & & (Monitoring well H) & & $06 / 27 / 95$ & $4,275.98$ & 280.35 & $3,995.63$ \\
\hline & & & & $04 / 17 / 96$ & $4,275.98$ & 281.20 & $3,994.78$ \\
\hline & & & & $06 / 25 / 96$ & $4,275.98$ & 282.15 & $3,993.83$ \\
\hline & & & & 08/19/96 & $4,275.98$ & 283.38 & $3,992.60$ \\
\hline & & & & 08/19/97 & $4,275.98$ & 283.68 & $3,992.30$ \\
\hline & & & & 04/06/98 & $4,275.98$ & 284.31 & $3,991.67$ \\
\hline & & & & 03/02/99 & $4,275.98$ & 286.66 & $3,989.32$ \\
\hline & & & & 08/31/99 & $4,275.98$ & 287.22 & $3,988.76$ \\
\hline & & & & $03 / 02 / 00$ & $4,275.98$ & 287.68 & $3,988.30$ \\
\hline & & & & $03 / 22 / 01$ & $4,275.98$ & 290.04 & $3,985.94$ \\
\hline & & & & $03 / 12 / 02$ & $4,275.98$ & 291.37 & $3,984.61$ \\
\hline
\end{tabular}


Table I-2. Altitudes of water levels in selected wells at Cannon Air Force Base and the surrounding area.—Continued [Monitoring well, Cannon Air Force Base monitoring well; Primary use of water: I, irrigation; O, observation; S, stock watering; U, unused; Z, other; W, withdrawal; ---, not recorded]

\begin{tabular}{|c|c|c|c|c|c|c|c|}
\hline $\begin{array}{c}\text { Map } \\
\text { identifier } \\
\text { (fig. I-1) }\end{array}$ & $\begin{array}{c}\text { U.S. Geological Survey } \\
\text { identifier }\end{array}$ & Township and range & $\begin{array}{c}\text { Primary } \\
\text { use of } \\
\text { water }\end{array}$ & $\begin{array}{c}\text { Water- } \\
\text { level } \\
\text { date }\end{array}$ & $\begin{array}{c}\text { Altitude } \\
\text { of land } \\
\text { surface } \\
\text { (feet above } \\
\text { NAVD 88) }\end{array}$ & $\begin{array}{c}\text { Water } \\
\text { level } \\
\text { (feet } \\
\text { below } \\
\text { land } \\
\text { surface) }\end{array}$ & $\begin{array}{c}\text { Altitude } \\
\text { of water } \\
\text { level } \\
\text { (feet above } \\
\text { NAVD 88) }\end{array}$ \\
\hline & & & & $03 / 20 / 03$ & $4,275.98$ & 294.07 & $3,981.91$ \\
\hline & & & & $04 / 02 / 03$ & $4,275.98$ & 294.00 & $3,981.98$ \\
\hline & & & & $02 / 27 / 04$ & $4,275.98$ & 292.98 & $3,983.00$ \\
\hline & & & & $05 / 26 / 04$ & $4,275.98$ & 296.22 & $3,979.76$ \\
\hline & & & & $06 / 15 / 04$ & $4,275.98$ & 296.53 & $3,979.45$ \\
\hline & & & & $08 / 12 / 04$ & $4,275.98$ & 296.94 & $3,979.04$ \\
\hline & & & & $10 / 21 / 04$ & $4,275.98$ & 297.51 & $3,978.47$ \\
\hline & & & & $01 / 10 / 05$ & $4,275.98$ & 297.05 & $3,978.93$ \\
\hline \multirow[t]{6}{*}{82} & 342309103180601 & 02N.35E.19.242 & 0 & $07 / 15 / 95$ & $4,270.55$ & 275.99 & $3,994.56$ \\
\hline & & (Monitoring well P) & & $07 / 24 / 95$ & $4,270.55$ & 276.13 & $3,994.42$ \\
\hline & & & & $08 / 23 / 95$ & $4,270.55$ & 276.48 & $3,994.07$ \\
\hline & & & & $02 / 27 / 96$ & $4,270.55$ & 276.45 & $3,994.10$ \\
\hline & & & & $04 / 16 / 96$ & $4,270.55$ & 277.06 & $3,993.49$ \\
\hline & & & & $06 / 25 / 96$ & $4,270.55$ & 278.33 & $3,992.22$ \\
\hline \multirow[t]{28}{*}{83} & 342310103160901 & 02N.35E.21.221122 & I & $01 / 06 / 56$ & 4,276 & 240.20 & 4,036 \\
\hline & & & & $01 / 11 / 57$ & 4,276 & 241.90 & 4,034 \\
\hline & & & & $01 / 13 / 58$ & 4,276 & 244.65 & 4,031 \\
\hline & & & & $01 / 14 / 59$ & 4,276 & 241.88 & 4,034 \\
\hline & & & & $01 / 15 / 60$ & 4,276 & 242.61 & 4,033 \\
\hline & & & & $01 / 19 / 61$ & 4,276 & 243.07 & 4,033 \\
\hline & & & & $01 / 05 / 62$ & 4,276 & 244.09 & 4,032 \\
\hline & & & & $01 / 14 / 64$ & 4,276 & 250.83 & 4,025 \\
\hline & & & & $02 / 17 / 65$ & 4,276 & 249.02 & 4,027 \\
\hline & & & & $01 / 10 / 68$ & 4,276 & 253.97 & 4,022 \\
\hline & & & & $01 / 07 / 69$ & 4,276 & 256.11 & 4,020 \\
\hline & & & & $01 / 06 / 70$ & 4,276 & 257.14 & 4,019 \\
\hline & & & & $01 / 06 / 71$ & 4,276 & 273.26 & 4,003 \\
\hline & & & & $01 / 05 / 72$ & 4,276 & 261.08 & 4,015 \\
\hline & & & & $01 / 04 / 73$ & 4,276 & 262.75 & 4,013 \\
\hline & & & & $01 / 04 / 75$ & 4,276 & 269.92 & 4,006 \\
\hline & & & & $01 / 06 / 76$ & 4,276 & 268.50 & 4,008 \\
\hline & & & & $01 / 05 / 77$ & 4,276 & 282.36 & 3,994 \\
\hline & & & & $01 / 06 / 79$ & 4,276 & 270.34 & 4,006 \\
\hline & & & & $01 / 07 / 80$ & 4,276 & 271.68 & 4,004 \\
\hline & & & & $01 / 10 / 81$ & 4,276 & 284.08 & 3,992 \\
\hline & & & & $01 / 11 / 82$ & 4,276 & 273.44 & 4,003 \\
\hline & & & & $01 / 10 / 83$ & 4,276 & 274.03 & 4,002 \\
\hline & & & & $01 / 16 / 84$ & 4,276 & 274.04 & 4,002 \\
\hline & & & & $01 / 14 / 85$ & 4,276 & 274.55 & 4,001 \\
\hline & & & & $01 / 13 / 86$ & 4,276 & 278.98 & 3,997 \\
\hline & & & & $01 / 12 / 87$ & 4,276 & 275.15 & 4,001 \\
\hline & & & & $01 / 12 / 88$ & 4,276 & 275.80 & 4,000 \\
\hline \multirow[t]{2}{*}{84} & 342310103165901 & 02N.35E.21.11111 & I & $02 / 10 / 54$ & 4,276 & 232.87 & 4,043 \\
\hline & & & & $01 / 30 / 55$ & 4,276 & 233.66 & 4,042 \\
\hline
\end{tabular}


Table I-2. Altitudes of water levels in selected wells at Cannon Air Force Base and the surrounding area.-Continued [Monitoring well, Cannon Air Force Base monitoring well; Primary use of water: I, irrigation; O, observation; S, stock watering; U, unused; Z, other; W, withdrawal; ---, not recorded]

\begin{tabular}{|c|c|c|c|c|c|c|c|}
\hline $\begin{array}{c}\text { Map } \\
\text { identifier } \\
\text { (fig. I-1) }\end{array}$ & $\begin{array}{l}\text { U.S. Geological Survey } \\
\text { identifier }\end{array}$ & Township and range & $\begin{array}{c}\text { Primary } \\
\text { use of } \\
\text { water }\end{array}$ & $\begin{array}{c}\text { Water- } \\
\text { level } \\
\text { date }\end{array}$ & $\begin{array}{c}\text { Altitude } \\
\text { of land } \\
\text { surface } \\
\text { (feet above } \\
\text { NAVD 88) }\end{array}$ & $\begin{array}{c}\text { Water } \\
\text { level } \\
\text { (feet } \\
\text { below } \\
\text { land } \\
\text { surface) }\end{array}$ & $\begin{array}{c}\text { Altitude } \\
\text { of water } \\
\text { level } \\
\text { (feet above } \\
\text { NAVD 88) }\end{array}$ \\
\hline & & & & 01/07/77 & 4,276 & 269.04 & 4,007 \\
\hline & & & & $02 / 04 / 82$ & 4,276 & 269.79 & 4,006 \\
\hline & & & & 01/16/87 & 4,276 & 271.03 & 4,005 \\
\hline & & & & $02 / 21 / 97$ & 4,276 & 285.38 & 3,991 \\
\hline & & & & 03/04/04 & 4,276 & 292.47 & 3,984 \\
\hline \multirow[t]{5}{*}{85} & 342310103180801 & --- & 0 & $02 / 27 / 04$ & $4,270.85$ & 290.00 & $3,980.85$ \\
\hline & & (Monitoring well $\mathrm{Pa}$ ) & & 05/26/04 & $4,270.85$ & 291.46 & $3,979.39$ \\
\hline & & & & $08 / 12 / 04$ & $4,270.85$ & 292.82 & $3,978.03$ \\
\hline & & & & $10 / 21 / 04$ & $4,270.85$ & 293.20 & $3,977.65$ \\
\hline & & & & $01 / 10 / 05$ & $4,270.85$ & 292.37 & $3,978.48$ \\
\hline \multirow[t]{19}{*}{86} & 342313103180801 & 02N.35E.19.224 & 0 & 09/13/94 & $4,276.46$ & 279.31 & $3,997.15$ \\
\hline & & (Monitoring well G) & & $06 / 27 / 95$ & $4,276.46$ & 281.08 & $3,995.38$ \\
\hline & & & & $04 / 17 / 96$ & $4,276.46$ & 281.89 & $3,994.57$ \\
\hline & & & & $06 / 25 / 96$ & $4,276.46$ & 282.86 & $3,993.60$ \\
\hline & & & & 08/19/96 & $4,276.46$ & 283.96 & $3,992.50$ \\
\hline & & & & 08/20/97 & $4,276.46$ & 284.46 & $3,992.00$ \\
\hline & & & & 04/06/98 & $4,276.46$ & 284.83 & $3,991.63$ \\
\hline & & & & $03 / 02 / 99$ & $4,276.46$ & 287.03 & $3,989.43$ \\
\hline & & & & $08 / 31 / 99$ & $4,276.46$ & 287.60 & $3,988.86$ \\
\hline & & & & $03 / 02 / 00$ & $4,276.46$ & 287.99 & $3,988.47$ \\
\hline & & & & 03/22/01 & $4,276.46$ & 290.34 & $3,986.12$ \\
\hline & & & & $03 / 14 / 02$ & $4,276.46$ & 291.59 & $3,984.87$ \\
\hline & & & & 03/20/03 & $4,276.46$ & 294.44 & $3,982.02$ \\
\hline & & & & $02 / 27 / 04$ & $4,276.46$ & 293.19 & $3,983.27$ \\
\hline & & & & 05/26/04 & $4,276.46$ & 295.53 & $3,980.93$ \\
\hline & & & & 06/15/04 & $4,276.46$ & 296.87 & $3,979.59$ \\
\hline & & & & $08 / 12 / 04$ & $4,276.46$ & 297.52 & $3,978.94$ \\
\hline & & & & $10 / 21 / 04$ & $4,276.46$ & 298.07 & $3,978.39$ \\
\hline & & & & 01/10/05 & $4,276.46$ & 297.33 & $3,979.13$ \\
\hline \multirow[t]{8}{*}{87} & 342317103174701 & 02N.35E.20.123 & 0 & $06 / 27 / 95$ & $4,265.88$ & 273.31 & $3,992.57$ \\
\hline & & (Monitoring well N) & & $02 / 27 / 96$ & $4,265.88$ & 273.59 & $3,992.29$ \\
\hline & & & & $11 / 05 / 03$ & 4,265.88 & 287.78 & $3,978.10$ \\
\hline & & & & $02 / 27 / 04$ & $4,265.88$ & 284.92 & $3,980.96$ \\
\hline & & & & $05 / 26 / 04$ & $4,265.88$ & 288.33 & $3,977.55$ \\
\hline & & & & $08 / 12 / 04$ & $4,265.88$ & 291.25 & $3,974.63$ \\
\hline & & & & $10 / 21 / 04$ & $4,265.88$ & 289.47 & $3,976.41$ \\
\hline & & & & 01/10/05 & $4,265.88$ & 287.76 & $3,978.12$ \\
\hline 88 & 342320103142501 & 02N.35E.23.21113 & I & $03 / 06 / 62$ & 4,267 & 249.91 & $4,017.00$ \\
\hline \multirow[t]{4}{*}{89} & 342321103181001 & 02N.35E.19.222 & 0 & $09 / 12 / 94$ & $4,274.93$ & 276.99 & $3,997.94$ \\
\hline & & (Monitoring well F) & & $06 / 27 / 95$ & $4,274.93$ & 278.91 & $3,996.02$ \\
\hline & & & & $04 / 16 / 96$ & $4,274.93$ & 279.17 & $3,995.76$ \\
\hline & & & & $06 / 26 / 96$ & $4,274.93$ & 280.50 & $3,994.43$ \\
\hline
\end{tabular}


Table I-2. Altitudes of water levels in selected wells at Cannon Air Force Base and the surrounding area.-Continued [Monitoring well, Cannon Air Force Base monitoring well; Primary use of water: I, irrigation; O, observation; S, stock watering; U, unused; Z, other; W, withdrawal; ---, not recorded]

\begin{tabular}{|c|c|c|c|c|c|c|c|}
\hline $\begin{array}{c}\text { Map } \\
\text { identifier } \\
\text { (fig. I-1) }\end{array}$ & $\begin{array}{l}\text { U.S. Geological Survey } \\
\text { identifier }\end{array}$ & Township and range & $\begin{array}{c}\text { Primary } \\
\text { use of } \\
\text { water }\end{array}$ & $\begin{array}{c}\text { Water- } \\
\text { level } \\
\text { date }\end{array}$ & $\begin{array}{c}\text { Altitude } \\
\text { of land } \\
\text { surface } \\
\text { (feet above } \\
\text { NAVD 88) }\end{array}$ & $\begin{array}{c}\text { Water } \\
\text { level } \\
\text { (feet } \\
\text { below } \\
\text { land } \\
\text { surface) }\end{array}$ & $\begin{array}{c}\text { Altitude } \\
\text { of water } \\
\text { level } \\
\text { (feet above } \\
\text { NAVD 88) }\end{array}$ \\
\hline & & & & $08 / 19 / 96$ & $4,274.93$ & 282.39 & $3,992.54$ \\
\hline & & & & $08 / 20 / 97$ & $4,274.93$ & 281.75 & $3,993.18$ \\
\hline & & & & $04 / 06 / 98$ & $4,274.93$ & 282.21 & $3,992.72$ \\
\hline & & & & 03/02/99 & $4,274.93$ & 284.30 & $3,990.63$ \\
\hline & & & & 08/31/99 & $4,274.93$ & 284.74 & $3,990.19$ \\
\hline & & & & $03 / 20 / 00$ & $4,274.93$ & 285.15 & $3,989.78$ \\
\hline & & & & 03/22/01 & $4,274.93$ & 287.41 & $3,987.52$ \\
\hline & & & & 08/21/01 & $4,274.93$ & 287.81 & $3,987.12$ \\
\hline & & & & 03/14/02 & $4,274.93$ & 289.23 & $3,985.70$ \\
\hline & & & & 03/18/03 & $4,274.93$ & 291.53 & $3,983.40$ \\
\hline & & & & $02 / 27 / 04$ & $4,274.93$ & 289.78 & $3,985.15$ \\
\hline & & & & $05 / 26 / 04$ & $4,274.93$ & 293.99 & $3,980.94$ \\
\hline & & & & $06 / 16 / 04$ & $4,274.93$ & 294.29 & $3,980.64$ \\
\hline & & & & $08 / 12 / 04$ & $4,274.93$ & 294.96 & $3,979.97$ \\
\hline & & & & $10 / 21 / 04$ & $4,274.93$ & 295.64 & $3,979.29$ \\
\hline & & & & $01 / 10 / 05$ & $4,274.93$ & 294.64 & $3,980.29$ \\
\hline \multirow[t]{15}{*}{90} & 342323103145601 & 02N.35E.23.111 & $U$ & $01 / 10 / 83$ & 4,279 & 289.73 & 3,989 \\
\hline & & & & $01 / 19 / 84$ & 4,279 & 290.74 & 3,988 \\
\hline & & & & $01 / 14 / 85$ & 4,279 & 293.12 & 3,986 \\
\hline & & & & $01 / 13 / 86$ & 4,279 & 293.89 & 3,985 \\
\hline & & & & $01 / 12 / 87$ & 4,279 & 294.95 & 3,984 \\
\hline & & & & $01 / 13 / 88$ & 4,279 & 292.25 & 3,987 \\
\hline & & & & $01 / 04 / 90$ & 4,279 & 294.15 & 3,985 \\
\hline & & & & $01 / 05 / 91$ & 4,279 & 294.71 & 3,984 \\
\hline & & & & $01 / 02 / 92$ & 4,279 & 298.90 & 3,980 \\
\hline & & & & $01 / 08 / 93$ & 4,279 & 300.47 & 3,979 \\
\hline & & & & $01 / 05 / 94$ & 4,279 & 304.31 & 3,975 \\
\hline & & & & $01 / 05 / 95$ & 4,279 & 316.26 & 3,963 \\
\hline & & & & $01 / 11 / 96$ & 4,279 & 299.81 & 3,979 \\
\hline & & & & $01 / 17 / 97$ & 4,279 & 301.01 & 3,978 \\
\hline & & & & $01 / 08 / 98$ & 4,279 & 301.63 & 3,977 \\
\hline \multirow[t]{4}{*}{91} & 342323103180801 & 02N.35E.20.111 & 0 & $05 / 26 / 04$ & $4,272.31$ & 291.85 & $3,980.46$ \\
\hline & & (Monitoring well Ra) & & 08/12/04 & $4,272.31$ & 293.18 & $3,979.13$ \\
\hline & & & & $10 / 21 / 04$ & $4,272.31$ & 293.83 & $3,978.48$ \\
\hline & & & & $01 / 10 / 05$ & $4,272.31$ & 292.40 & $3,979.91$ \\
\hline \multirow[t]{2}{*}{92} & 342324103211401 & 02N.34E.23.11111 & I & $02 / 17 / 82$ & 4,317 & 287.62 & 4,029 \\
\hline & & & & $02 / 05 / 87$ & 4,317 & 290.39 & 4,027 \\
\hline \multirow[t]{2}{*}{93} & 342325103233601 & 02N.34E.17.43444 & I & $02 / 12 / 82$ & 4,334 & 265.47 & 4,069 \\
\hline & & & & $02 / 06 / 87$ & 4,334 & 251.50 & 4,083 \\
\hline \multirow[t]{3}{*}{94} & 342328103182401 & 02N.35E.18.434 & 0 & 09/13/94 & $4,279.70$ & 280.55 & $3,999.15$ \\
\hline & & (Monitoring well E) & & $06 / 27 / 95$ & $4,279.70$ & 282.56 & $3,997.14$ \\
\hline & & & & $04 / 16 / 96$ & $4,279.70$ & 283.70 & $3,996.00$ \\
\hline
\end{tabular}


Table I-2. Altitudes of water levels in selected wells at Cannon Air Force Base and the surrounding area.-Continued [Monitoring well, Cannon Air Force Base monitoring well; Primary use of water: I, irrigation; O, observation; S, stock watering; U, unused; Z, other; W, withdrawal; ---, not recorded].

\begin{tabular}{|c|c|c|c|c|c|c|c|}
\hline $\begin{array}{c}\text { Map } \\
\text { identifier } \\
\text { (fig. I-1) }\end{array}$ & $\begin{array}{l}\text { U.S. Geological Survey } \\
\text { identifier }\end{array}$ & Township and range & $\begin{array}{c}\text { Primary } \\
\text { use of } \\
\text { water }\end{array}$ & $\begin{array}{c}\text { Water- } \\
\text { level } \\
\text { date }\end{array}$ & $\begin{array}{c}\text { Altitude } \\
\text { of land } \\
\text { surface } \\
\text { (feet above } \\
\text { NAVD 88) }\end{array}$ & $\begin{array}{c}\text { Water } \\
\text { level } \\
\text { (feet } \\
\text { below } \\
\text { land } \\
\text { surface) }\end{array}$ & $\begin{array}{c}\text { Altitude } \\
\text { of water } \\
\text { level } \\
\text { (feet above } \\
\text { NAVD 88) }\end{array}$ \\
\hline & & & & $06 / 24 / 96$ & $4,279.70$ & 284.32 & $3,995.38$ \\
\hline & & & & $08 / 19 / 96$ & $4,279.70$ & 284.68 & $3,995.02$ \\
\hline & & & & 08/19/97 & $4,279.70$ & 285.23 & $3,994.47$ \\
\hline & & & & $04 / 06 / 98$ & $4,279.70$ & 285.77 & $3,993.93$ \\
\hline & & & & 03/02/99 & $4,279.70$ & 287.85 & $3,991.85$ \\
\hline & & & & 08/31/99 & $4,279.70$ & 288.19 & $3,991.51$ \\
\hline & & & & $03 / 02 / 00$ & $4,279.70$ & 288.74 & $3,990.96$ \\
\hline & & & & $03 / 15 / 00$ & $4,279.70$ & 288.93 & $3,990.77$ \\
\hline & & & & 03/22/01 & $4,279.70$ & 291.04 & $3,988.66$ \\
\hline & & & & 03/12/02 & $4,279.70$ & 292.33 & $3,987.37$ \\
\hline & & & & 03/21/03 & $4,279.70$ & 294.82 & $3,984.88$ \\
\hline & & & & $02 / 27 / 04$ & $4,279.70$ & 294.10 & $3,985.60$ \\
\hline & & & & $05 / 26 / 04$ & $4,279.70$ & 297.27 & $3,982.43$ \\
\hline & & & & $06 / 16 / 04$ & $4,279.70$ & 297.66 & $3,982.04$ \\
\hline & & & & $08 / 12 / 04$ & $4,279.70$ & 298.01 & $3,981.69$ \\
\hline & & & & $10 / 21 / 04$ & $4,279.70$ & 298.66 & $3,981.04$ \\
\hline & & & & $01 / 10 / 05$ & $4,279.70$ & 297.99 & $3,981.71$ \\
\hline \multirow[t]{7}{*}{95} & 342338103203701 & 02N.34E.14.41112 & I & $01 / 23 / 67$ & 4,329 & 273.89 & 4,055 \\
\hline & & & & $01 / 11 / 72$ & 4,329 & 286.40 & 4,043 \\
\hline & & & & $01 / 05 / 77$ & 4,329 & 295.70 & 4,033 \\
\hline & & & & $02 / 17 / 82$ & 4,329 & 305.74 & 4,023 \\
\hline & & & & 02/06/87 & 4,329 & 308.89 & 4,020 \\
\hline & & & & 03/07/97 & 4,329 & 312.50 & 4,017 \\
\hline & & & & 03/05/04 & 4,329 & 319.77 & 4,009 \\
\hline 96 & 342338103210701 & 02N.34E.14.31121 & Z & $02 / 27 / 62$ & 4,337 & 268.46 & 4,069 \\
\hline \multirow[t]{3}{*}{97} & 342344103224901 & 02N.34E.16.32422 & 1 & $02 / 17 / 82$ & 4,330 & 285.43 & 4,045 \\
\hline & & & & $02 / 06 / 87$ & 4,330 & 280.02 & 4,050 \\
\hline & & & & $03 / 13 / 92$ & 4,330 & 284.05 & 4,046 \\
\hline \multirow[t]{8}{*}{98} & 342348103175801 & 02N.35E.17.3121 & 0 & $02 / 27 / 04$ & $4,296.95$ & 311.49 & $3,985.46$ \\
\hline & & (Monitoring well W) & & $03 / 11 / 04$ & $4,296.95$ & 314.32 & $3,982.63$ \\
\hline & & & & $04 / 29 / 04$ & $4,296.95$ & 314.81 & $3,982.14$ \\
\hline & & & & 05/26/04 & $4,296.95$ & 315.80 & $3,981.15$ \\
\hline & & & & $06 / 15 / 04$ & $4,296.95$ & 316.44 & $3,980.51$ \\
\hline & & & & $08 / 12 / 04$ & $4,296.95$ & 317.18 & $3,979.77$ \\
\hline & & & & $10 / 21 / 04$ & $4,296.95$ & 317.91 & $3,979.04$ \\
\hline & & & & $01 / 10 / 05$ & $4,296.95$ & 315.33 & $3,981.62$ \\
\hline 99 & 342353103214601 & 02N.34E.15.14442 & 1 & $02 / 18 / 82$ & 4,341 & 310.01 & 4,031 \\
\hline \multirow[t]{3}{*}{100} & 342358103151601 & 02N.35E.15.232411 & U & $10 / 27 / 77$ & 4,309 & 315.55 & 3,993 \\
\hline & & & & $01 / 28 / 82$ & 4,309 & 317.39 & 3,992 \\
\hline & & & & $01 / 15 / 87$ & 4,309 & 319.40 & 3,990 \\
\hline \multirow[t]{2}{*}{101} & 342401103155901 & 02N.35E.15.13111 & 1 & $01 / 28 / 82$ & 4,314 & 314.71 & 3,999 \\
\hline & & & & $01 / 15 / 87$ & 4,314 & 316.76 & 3,997 \\
\hline
\end{tabular}


Table I-2. Altitudes of water levels in selected wells at Cannon Air Force Base and the surrounding area.-Continued [Monitoring well, Cannon Air Force Base monitoring well; Primary use of water: I, irrigation; O, observation; S, stock watering; U, unused; Z, other; W, withdrawal; ---, not recorded]

\begin{tabular}{|c|c|c|c|c|c|c|c|}
\hline $\begin{array}{c}\text { Map } \\
\text { identifier } \\
\text { (fig. I-1) }\end{array}$ & $\begin{array}{l}\text { U.S. Geological Survey } \\
\text { identifier }\end{array}$ & Township and range & $\begin{array}{c}\text { Primary } \\
\text { use of } \\
\text { water }\end{array}$ & $\begin{array}{c}\text { Water- } \\
\text { level } \\
\text { date }\end{array}$ & $\begin{array}{l}\text { Altitude } \\
\text { of land } \\
\text { surface } \\
\text { (feet above } \\
\text { NAVD 88) }\end{array}$ & $\begin{array}{c}\text { Water } \\
\text { level } \\
\text { (feet } \\
\text { below } \\
\text { land } \\
\text { surface) }\end{array}$ & $\begin{array}{c}\text { Altitude } \\
\text { of water } \\
\text { level } \\
\text { (feet above } \\
\text { NAVD 88) }\end{array}$ \\
\hline \multirow[t]{5}{*}{102} & 342404103210401 & 02N.34E.14.11121 & I & $01 / 30 / 67$ & 4,353 & 301.75 & 4,051 \\
\hline & & & & $01 / 13 / 72$ & 4,353 & 316.85 & 4,036 \\
\hline & & & & $01 / 05 / 77$ & 4,353 & 325.47 & 4,028 \\
\hline & & & & $02 / 16 / 82$ & 4,353 & 336.21 & 4,017 \\
\hline & & & & $02 / 05 / 87$ & 4,353 & 338.90 & 4,014 \\
\hline \multirow[t]{2}{*}{103} & 342405103170301 & 02N.35E.17.22442 & I & $02 / 10 / 82$ & 4,305 & 295.29 & 4,010 \\
\hline & & & & $01 / 27 / 87$ & 4,305 & 297.58 & 4,007 \\
\hline \multirow[t]{2}{*}{104} & 342405103235001 & 02N.34E.17.122224 & --- & $01 / 23 / 67$ & 4,357 & 265.65 & 4,091 \\
\hline & & & & $01 / 12 / 72$ & 4,357 & 268.23 & 4,089 \\
\hline \multirow[t]{2}{*}{105} & 342406103183401 & 02N.35E.07.34442 & W & $03 / 07 / 62$ & 4,325 & 274.13 & 4,051 \\
\hline & & & & $01 / 11 / 72$ & 4,325 & 293.78 & 4,031 \\
\hline \multirow[t]{3}{*}{106} & 342418103180601 & 02N.35E.07.44442 & W & $02 / 16 / 82$ & 4,315 & 298.66 & 4,016 \\
\hline & & & & $01 / 16 / 87$ & 4,315 & 303.97 & 4,011 \\
\hline & & & & $02 / 21 / 97$ & 4,315 & 309.55 & 4,005 \\
\hline \multirow[t]{7}{*}{107} & 342418103201201 & 02N.34E.13.1111 & 0 & $11 / 06 / 03$ & $4,324.82$ & 330.30 & $3,994.52$ \\
\hline & & (Monitoring well V) & & 01/16/04 & $4,324.82$ & 330.04 & $3,994.78$ \\
\hline & & & & 03/11/04 & $4,324.82$ & 330.59 & $3,994.23$ \\
\hline & & & & $04 / 20 / 04$ & $4,324.82$ & 330.31 & $3,994.51$ \\
\hline & & & & $06 / 14 / 04$ & $4,324.82$ & 330.64 & $3,994.18$ \\
\hline & & & & $10 / 21 / 04$ & $4,324.82$ & 331.04 & $3,993.78$ \\
\hline & & & & $01 / 10 / 05$ & $4,324.82$ & 330.74 & $3,994.08$ \\
\hline \multirow[t]{4}{*}{108} & 342419103232301 & 02N.34E.08.442114 & I & $01 / 05 / 77$ & 4,362 & 297.19 & 4,065 \\
\hline & & & & $02 / 18 / 82$ & 4,362 & 299.48 & 4,063 \\
\hline & & & & $02 / 04 / 87$ & 4,362 & 297.05 & 4,065 \\
\hline & & & & 03/07/97 & 4,362 & 301.18 & 4,061 \\
\hline \multirow[t]{2}{*}{109} & 342424103220901 & 02N.34E.10.332333 & I & $02 / 05 / 87$ & 4,363 & 338.06 & 4,025 \\
\hline & & & & $04 / 28 / 87$ & 4,363 & 337.54 & 4,025 \\
\hline 110 & 342435103223501 & 02N.34.E.09.400 & $U$ & --- & 4,364 & --- & --- \\
\hline \multirow[t]{13}{*}{111} & 342442103213601 & 02N.34E.10.23124 & I & $03 / 06 / 62$ & 4,365 & 293.12 & 4,072 \\
\hline & & & & $01 / 24 / 67$ & 4,365 & 308.65 & 4,056 \\
\hline & & & & $02 / 01 / 68$ & 4,365 & 311.05 & 4,054 \\
\hline & & & & $01 / 08 / 69$ & 4,365 & 313.46 & 4,052 \\
\hline & & & & $01 / 07 / 70$ & 4,365 & 316.59 & 4,048 \\
\hline & & & & $01 / 05 / 71$ & 4,365 & 318.78 & 4,046 \\
\hline & & & & $01 / 04 / 72$ & 4,365 & 324.42 & 4,041 \\
\hline & & & & $01 / 03 / 74$ & 4,365 & 333.66 & 4,031 \\
\hline & & & & $01 / 04 / 75$ & 4,365 & 336.68 & 4,028 \\
\hline & & & & $01 / 04 / 77$ & 4,365 & 341.00 & 4,024 \\
\hline & & & & $01 / 05 / 77$ & 4,365 & 351.40 & 4,014 \\
\hline & & & & 03/16/77 & 4,365 & 337.04 & 4,028 \\
\hline & & & & $01 / 06 / 79$ & 4,365 & 341.74 & 4,023 \\
\hline 112 & 342453103141901 & 02N.35E.11.21111 & 1 & $01 / 25 / 77$ & 4,319 & 323.40 & 3,996 \\
\hline
\end{tabular}


Table I-2. Altitudes of water levels in selected wells at Cannon Air Force Base and the surrounding area.-Continued [Monitoring well, Cannon Air Force Base monitoring well; Primary use of water: I, irrigation; O, observation; S, stock watering; U, unused; Z, other; W, withdrawal; ---, not recorded]

\begin{tabular}{|c|c|c|c|c|c|c|c|}
\hline $\begin{array}{c}\text { Map } \\
\text { identifier } \\
\text { (fig. I-1) }\end{array}$ & $\begin{array}{c}\text { U.S. Geological Survey } \\
\text { identifier }\end{array}$ & Township and range & $\begin{array}{c}\text { Primary } \\
\text { use of } \\
\text { water }\end{array}$ & $\begin{array}{c}\text { Water- } \\
\text { level } \\
\text { date }\end{array}$ & $\begin{array}{l}\text { Altitude } \\
\text { of land } \\
\text { surface } \\
\text { (feet above } \\
\text { NAVD 88) }\end{array}$ & $\begin{array}{c}\text { Water } \\
\text { level } \\
\text { (feet } \\
\text { below } \\
\text { land } \\
\text { surface) }\end{array}$ & $\begin{array}{c}\text { Altitude } \\
\text { of water } \\
\text { level } \\
\text { (feet above } \\
\text { NAVD 88) }\end{array}$ \\
\hline & & & & $01 / 26 / 82$ & 4,319 & 323.95 & 3,995 \\
\hline & & & & $01 / 15 / 87$ & 4,319 & 324.68 & 3,994 \\
\hline 113 & 342455103183301 & 02N.35E.07.122221 & I & $01 / 11 / 72$ & 4,344 & 311.90 & 4,032 \\
\hline \multirow[t]{7}{*}{114} & 342456103195201 & 02N.34E.12.11222 & I & $03 / 14 / 62$ & 4,354 & 266.57 & 4,087 \\
\hline & & & & $02 / 01 / 63$ & 4,354 & 298.18 & 4,056 \\
\hline & & & & $01 / 24 / 67$ & 4,354 & 307.69 & 4,046 \\
\hline & & & & $01 / 31 / 72$ & 4,354 & 317.67 & 4,036 \\
\hline & & & & $01 / 04 / 77$ & 4,354 & 333.25 & 4,021 \\
\hline & & & & $02 / 16 / 82$ & 4,354 & 346.37 & 4,008 \\
\hline & & & & $01 / 27 / 87$ & 4,354 & 348.53 & 4,005 \\
\hline \multirow[t]{13}{*}{115} & 342457103213901 & 02N.34E.10.21112 & 1 & $01 / 31 / 72$ & 4,365 & 322.52 & 4,042 \\
\hline & & & & $01 / 04 / 77$ & 4,365 & 338.29 & 4,027 \\
\hline & & & & $01 / 07 / 80$ & 4,365 & 344.82 & 4,020 \\
\hline & & & & $01 / 12 / 81$ & 4,365 & 348.93 & 4,016 \\
\hline & & & & $01 / 11 / 82$ & 4,365 & 348.71 & 4,016 \\
\hline & & & & $01 / 09 / 83$ & 4,365 & 350.54 & 4,014 \\
\hline & & & & $01 / 18 / 84$ & 4,365 & 351.21 & 4,014 \\
\hline & & & & $01 / 13 / 85$ & 4,365 & 349.98 & 4,015 \\
\hline & & & & $01 / 13 / 87$ & 4,365 & 349.01 & 4,016 \\
\hline & & & & $01 / 04 / 91$ & 4,365 & 348.73 & 4,016 \\
\hline & & & & $01 / 02 / 92$ & 4,365 & 347.73 & 4,017 \\
\hline & & & & $01 / 05 / 93$ & 4,365 & 347.11 & 4,018 \\
\hline & & & & $01 / 17 / 97$ & 4,365 & 354.77 & 4,010 \\
\hline \multirow[t]{19}{*}{116} & 342505103151801 & 02N.35E.10.21111 & I & $03 / 03 / 62$ & 4,336 & 303.74 & 4,032 \\
\hline & & & & $02 / 03 / 67$ & 4,336 & 326.32 & 4,010 \\
\hline & & & & $02 / 01 / 68$ & 4,336 & 323.63 & 4,012 \\
\hline & & & & $01 / 08 / 69$ & 4,336 & 326.12 & 4,010 \\
\hline & & & & $01 / 08 / 70$ & 4,336 & 326.38 & 4,010 \\
\hline & & & & $01 / 09 / 71$ & 4,336 & 331.36 & 4,005 \\
\hline & & & & $01 / 05 / 72$ & 4,336 & 334.21 & 4,002 \\
\hline & & & & $01 / 11 / 72$ & 4,336 & 334.49 & 4,002 \\
\hline & & & & $01 / 04 / 73$ & 4,336 & 334.22 & 4,002 \\
\hline & & & & $01 / 04 / 74$ & 4,336 & 337.65 & 3,998 \\
\hline & & & & $01 / 04 / 75$ & 4,336 & 345.22 & 3,991 \\
\hline & & & & $01 / 07 / 76$ & 4,336 & 350.19 & 3,986 \\
\hline & & & & $01 / 05 / 77$ & 4,336 & 361.74 & 3,974 \\
\hline & & & & $01 / 07 / 77$ & 4,336 & 338.05 & 3,998 \\
\hline & & & & 03/16/77 & 4,336 & 338.44 & 3,998 \\
\hline & & & & $01 / 06 / 79$ & 4,336 & 338.96 & 3,997 \\
\hline & & & & $01 / 08 / 80$ & 4,336 & 340.03 & 3,996 \\
\hline & & & & $01 / 12 / 81$ & 4,336 & 340.23 & 3,996 \\
\hline & & & & $01 / 09 / 82$ & 4,336 & 339.02 & 3,997 \\
\hline
\end{tabular}


Table I-2. Altitudes of water levels in selected wells at Cannon Air Force Base and the surrounding area.-Continued [Monitoring well, Cannon Air Force Base monitoring well; Primary use of water: I, irrigation; O, observation; S, stock watering; U, unused; Z, other; W, withdrawal; ---, not recorded]

\begin{tabular}{|c|c|c|c|c|c|c|c|}
\hline $\begin{array}{c}\text { Map } \\
\text { identifier } \\
\text { (fig. I-1) }\end{array}$ & $\begin{array}{c}\text { U.S. Geological Survey } \\
\text { identifier }\end{array}$ & Township and range & $\begin{array}{c}\text { Primary } \\
\text { use of } \\
\text { water }\end{array}$ & $\begin{array}{c}\text { Water- } \\
\text { level } \\
\text { date }\end{array}$ & $\begin{array}{c}\text { Altitude } \\
\text { of land } \\
\text { surface } \\
\text { (feet above } \\
\text { NAVD 88) }\end{array}$ & $\begin{array}{c}\text { Water } \\
\text { level } \\
\text { (feet } \\
\text { below } \\
\text { land } \\
\text { surface) }\end{array}$ & $\begin{array}{c}\text { Altitude } \\
\text { of water } \\
\text { level } \\
\text { (feet above } \\
\text { NAVD 88) }\end{array}$ \\
\hline & & & & $01 / 10 / 83$ & 4,336 & 338.54 & 3,997 \\
\hline & & & & $01 / 18 / 84$ & 4,336 & 339.05 & 3,997 \\
\hline & & & & $01 / 13 / 85$ & 4,336 & 337.77 & 3,998 \\
\hline & & & & $01 / 11 / 86$ & 4,336 & 338.94 & 3,997 \\
\hline & & & & $01 / 13 / 87$ & 4,336 & 338.39 & 3,998 \\
\hline & & & & $01 / 12 / 88$ & 4,336 & 337.62 & 3,998 \\
\hline & & & & $01 / 04 / 91$ & 4,336 & 340.74 & 3,995 \\
\hline & & & & $01 / 03 / 92$ & 4,336 & 340.65 & 3,995 \\
\hline & & & & $01 / 05 / 93$ & 4,336 & 340.06 & 3,996 \\
\hline & & & & $01 / 05 / 94$ & 4,336 & 341.19 & 3,995 \\
\hline & & & & $01 / 04 / 95$ & 4,336 & 342.39 & 3,994 \\
\hline & & & & $01 / 11 / 96$ & 4,336 & 343.59 & 3,992 \\
\hline & & & & $01 / 06 / 98$ & 4,336 & 344.64 & 3,991 \\
\hline \multirow[t]{2}{*}{117} & 342506103164701 & 02N.35E.09.12111 & I & $01 / 29 / 82$ & 4,345 & 348.38 & 3,997 \\
\hline & & & & $01 / 16 / 87$ & 4,345 & 346.29 & 3,999 \\
\hline \multirow[t]{2}{*}{118} & 342506103174201 & 02N.35E.08.12211 & I & $01 / 29 / 82$ & 4,349 & 329.92 & 4,019 \\
\hline & & & & $01 / 16 / 87$ & 4,349 & 330.39 & 4,019 \\
\hline \multirow[t]{2}{*}{119} & 342509103203801 & 02N.34E.02.43111 & I & $01 / 04 / 77$ & 4,369 & 340.77 & 4,028 \\
\hline & & & & $02 / 05 / 87$ & 4,369 & 356.62 & 4,012 \\
\hline \multirow[t]{20}{*}{120} & 342519103230101 & 02N.34E.04.32133 & I & $03 / 03 / 62$ & 4,394 & 313.16 & 4,081 \\
\hline & & & & $01 / 24 / 67$ & 4,394 & 326.38 & 4,068 \\
\hline & & & & $02 / 01 / 68$ & 4,394 & 331.65 & 4,062 \\
\hline & & & & $01 / 08 / 69$ & 4,394 & 336.44 & 4,058 \\
\hline & & & & $01 / 07 / 70$ & 4,394 & 337.87 & 4,056 \\
\hline & & & & $01 / 07 / 71$ & 4,394 & 342.15 & 4,052 \\
\hline & & & & $01 / 04 / 72$ & 4,394 & 352.37 & 4,042 \\
\hline & & & & $01 / 03 / 73$ & 4,394 & 353.37 & 4,041 \\
\hline & & & & $01 / 03 / 74$ & 4,394 & 352.81 & 4,041 \\
\hline & & & & $01 / 03 / 75$ & 4,394 & 360.02 & 4,034 \\
\hline & & & & $01 / 06 / 76$ & 4,394 & 367.78 & 4,026 \\
\hline & & & & $01 / 05 / 77$ & 4,394 & 364.06 & 4,030 \\
\hline & & & & $01 / 08 / 78$ & 4,394 & 368.60 & 4,025 \\
\hline & & & & $01 / 06 / 79$ & 4,394 & 365.88 & 4,028 \\
\hline & & & & $01 / 07 / 80$ & 4,394 & 366.77 & 4,027 \\
\hline & & & & $01 / 12 / 81$ & 4,394 & 371.56 & 4,022 \\
\hline & & & & $01 / 11 / 82$ & 4,394 & 368.25 & 4,026 \\
\hline & & & & $01 / 09 / 83$ & 4,394 & 369.17 & 4,025 \\
\hline & & & & $01 / 13 / 85$ & 4,394 & 368.22 & 4,026 \\
\hline & & & & $01 / 11 / 86$ & 4,394 & 366.96 & 4,027 \\
\hline \multirow[t]{3}{*}{121} & 342520103165601 & 02N.35E.04.31111 & I & $04 / 21 / 54$ & 4,356 & 295.49 & 4,061 \\
\hline & & & & $01 / 29 / 55$ & 4,356 & 300.79 & 4,055 \\
\hline & & & & $01 / 09 / 56$ & 4,356 & 303.90 & 4,052 \\
\hline
\end{tabular}


Table I-2. Altitudes of water levels in selected wells at Cannon Air Force Base and the surrounding area.-Continued [Monitoring well, Cannon Air Force Base monitoring well; Primary use of water: I, irrigation; O, observation; S, stock watering; U, unused; Z, other; W, withdrawal; ---, not recorded].

\begin{tabular}{|c|c|c|c|c|c|c|c|}
\hline $\begin{array}{c}\text { Map } \\
\text { identifier } \\
\text { (fig. I-1) }\end{array}$ & $\begin{array}{l}\text { U.S. Geological Survey } \\
\text { identifier }\end{array}$ & Township and range & $\begin{array}{l}\text { Primary } \\
\text { use of } \\
\text { water }\end{array}$ & $\begin{array}{l}\text { Water- } \\
\text { level } \\
\text { date }\end{array}$ & $\begin{array}{c}\text { Altitude } \\
\text { of land } \\
\text { surface } \\
\text { (feet above } \\
\text { NAVD 88) }\end{array}$ & $\begin{array}{c}\text { Water } \\
\text { level } \\
\text { (feet } \\
\text { below } \\
\text { land } \\
\text { surface) }\end{array}$ & $\begin{array}{c}\text { Altitude } \\
\text { of water } \\
\text { level } \\
\text { (feet above } \\
\text { NAVD 88) }\end{array}$ \\
\hline & & & & $01 / 15 / 57$ & 4,356 & 306.07 & 4,050 \\
\hline & & & & $01 / 22 / 58$ & 4,356 & 306.98 & 4,049 \\
\hline & & & & $01 / 19 / 61$ & 4,356 & 308.17 & 4,048 \\
\hline & & & & $01 / 17 / 62$ & 4,356 & 308.80 & 4,047 \\
\hline & & & & $01 / 14 / 64$ & 4,356 & 313.46 & 4,043 \\
\hline & & & & $02 / 17 / 65$ & 4,356 & 317.32 & 4,039 \\
\hline & & & & 01/07/71 & 4,356 & 331.56 & 4,024 \\
\hline & & & & $01 / 26 / 77$ & 4,356 & 346.41 & 4,010 \\
\hline \multirow[t]{2}{*}{122} & 342521103221801 & 02N.34E.04.44222 & 1 & 02/18/82 & 4,381 & 359.73 & 4,021 \\
\hline & & & & $02 / 05 / 87$ & 4,381 & 358.32 & 4,023 \\
\hline \multirow[t]{3}{*}{123} & 342522103203801 & 02N.34E.02.41111 & Z & $03 / 03 / 62$ & 4,373 & 302.23 & 4,071 \\
\hline & & & & $01 / 24 / 67$ & 4,373 & 320.75 & 4,052 \\
\hline & & & & $01 / 31 / 72$ & 4,373 & 329.04 & 4,044 \\
\hline 124 & 342523103225301 & 02N.34E.04.32211 & 1 & $01 / 04 / 77$ & 4,391 & 361.26 & 4,030 \\
\hline \multirow[t]{3}{*}{125} & 342532103180501 & 02N.35E.05.31111 & 1 & $01 / 29 / 82$ & 4,362 & 342.88 & 4,019 \\
\hline & & & & $01 / 16 / 87$ & 4,362 & 343.18 & 4,019 \\
\hline & & & & $02 / 21 / 97$ & 4,362 & 344.66 & 4,017 \\
\hline \multirow[t]{2}{*}{126} & 342533103145601 & 02N.35E.02.13333 & I & $01 / 29 / 82$ & 4,335 & 334.91 & 4,000 \\
\hline & & & & $01 / 16 / 87$ & 4,335 & 335.44 & 4,000 \\
\hline \multirow[t]{2}{*}{127} & 342535103190201 & 02N.35E.06.31211 & 1 & $01 / 29 / 82$ & 4,360 & 334.52 & 4,025 \\
\hline & & & & 01/30/87 & 4,360 & 334.71 & 4,025 \\
\hline \multirow[t]{2}{*}{128} & 342535103211501 & 02N.34E.03.20000 & 1 & $02 / 18 / 82$ & 4,391 & 365.33 & 4,026 \\
\hline & & & & 02/05/87 & 4,391 & 365.91 & 4,025 \\
\hline 129 & 342547103190201 & 02N.35E.06.11111 & 1 & $03 / 03 / 62$ & 4,375 & 307.15 & 4,068 \\
\hline \multirow[t]{18}{*}{130} & 342548103193601 & 02N.34E.01.12222 & I & $03 / 14 / 62$ & 4,384 & 315.37 & 4,069 \\
\hline & & & & $01 / 24 / 67$ & 4,384 & 320.26 & 4,064 \\
\hline & & & & 02/01/68 & 4,384 & 325.65 & 4,058 \\
\hline & & & & $01 / 08 / 69$ & 4,384 & 329.27 & 4,055 \\
\hline & & & & $01 / 07 / 70$ & 4,384 & 331.00 & 4,053 \\
\hline & & & & $01 / 05 / 71$ & 4,384 & 333.45 & 4,051 \\
\hline & & & & $01 / 05 / 72$ & 4,384 & 336.75 & 4,047 \\
\hline & & & & $01 / 11 / 72$ & 4,384 & 334.70 & 4,049 \\
\hline & & & & $01 / 03 / 73$ & 4,384 & 336.12 & 4,048 \\
\hline & & & & $01 / 03 / 74$ & 4,384 & 342.14 & 4,042 \\
\hline & & & & $01 / 03 / 75$ & 4,384 & 338.13 & 4,046 \\
\hline & & & & 01/06/76 & 4,384 & 339.70 & 4,044 \\
\hline & & & & $01 / 04 / 77$ & 4,384 & 341.82 & 4,042 \\
\hline & & & & $01 / 05 / 77$ & 4,384 & 341.63 & 4,042 \\
\hline & & & & $01 / 07 / 78$ & 4,384 & 342.04 & 4,042 \\
\hline & & & & $01 / 06 / 79$ & 4,384 & 341.77 & 4,042 \\
\hline & & & & 01/07/80 & 4,384 & 342.35 & 4,042 \\
\hline & & & & $01 / 12 / 81$ & 4,384 & 342.91 & 4,041 \\
\hline
\end{tabular}


Table I-2. Altitudes of water levels in selected wells at Cannon Air Force Base and the surrounding area.-Continued [Monitoring well, Cannon Air Force Base monitoring well; Primary use of water: I, irrigation; O, observation; S, stock watering; U, unused; Z, other; W, withdrawal; ---, not recorded].

\begin{tabular}{|c|c|c|c|c|c|c|c|}
\hline $\begin{array}{c}\text { Map } \\
\text { identifier } \\
\text { (fig. I-1) }\end{array}$ & $\begin{array}{l}\text { U.S. Geological Survey } \\
\text { identifier }\end{array}$ & Township and range & $\begin{array}{c}\text { Primary } \\
\text { use of } \\
\text { water }\end{array}$ & $\begin{array}{c}\text { Water- } \\
\text { level } \\
\text { date }\end{array}$ & $\begin{array}{c}\text { Altitude } \\
\text { of land } \\
\text { surface } \\
\text { (feet above } \\
\text { NAVD 88) }\end{array}$ & $\begin{array}{c}\text { Water } \\
\text { level } \\
\text { (feet } \\
\text { below } \\
\text { land } \\
\text { surface) }\end{array}$ & $\begin{array}{c}\text { Altitude } \\
\text { of water } \\
\text { level } \\
\text { (feet above } \\
\text { NAVD 88) }\end{array}$ \\
\hline & & & & $01 / 11 / 82$ & 4,384 & 342.78 & 4,041 \\
\hline & & & & $01 / 09 / 83$ & 4,384 & 342.18 & 4,042 \\
\hline & & & & $01 / 18 / 84$ & 4,384 & 342.19 & 4,042 \\
\hline & & & & $01 / 13 / 85$ & 4,384 & 341.76 & 4,042 \\
\hline & & & & $01 / 13 / 87$ & 4,384 & 341.91 & 4,042 \\
\hline & & & & $01 / 12 / 88$ & 4,384 & 341.44 & 4,043 \\
\hline & & & & $01 / 04 / 91$ & 4,384 & 342.36 & 4,042 \\
\hline & & & & $01 / 02 / 92$ & 4,384 & 341.91 & 4,042 \\
\hline & & & & $01 / 05 / 93$ & 4,384 & 341.73 & 4,042 \\
\hline & & & & $01 / 05 / 94$ & 4,384 & 341.04 & 4,043 \\
\hline & & & & $01 / 05 / 95$ & 4,384 & 341.81 & 4,042 \\
\hline & & & & $01 / 17 / 97$ & 4,384 & 343.63 & 4,040 \\
\hline & & & & 03/03/04 & 4,384 & 348.09 & 4,036 \\
\hline 131 & 342551103232201 & 02N.34E.05.242 & I & --- & 4,400 & --- & --- \\
\hline 132 & 342559103155601 & 03N.35E.34.33333 & I & $01 / 13 / 87$ & 4,357 & 344.91 & 4,012 \\
\hline \multirow[t]{2}{*}{133} & 342559103165301 & 03N.35E.33.33344 & I & $02 / 23 / 82$ & 4,366 & 354.57 & 4,011 \\
\hline & & & & $01 / 13 / 87$ & 4,366 & 354.88 & 4,011 \\
\hline \multirow[t]{3}{*}{134} & 342559103183401 & 03N.35E.31.43333 & I & $02 / 23 / 82$ & 4,370 & 345.90 & 4,024 \\
\hline & & & & $01 / 13 / 87$ & 4,370 & 333.18 & 4,037 \\
\hline & & & & $04 / 03 / 87$ & 4,370 & 333.10 & 4,037 \\
\hline \multirow[t]{2}{*}{135} & 342600103232001 & 02N.34E.05.22222 & I & $02 / 18 / 82$ & 4,409 & 377.17 & 4,032 \\
\hline & & & & $01 / 27 / 87$ & 4,409 & 372.23 & 4,037 \\
\hline \multirow[t]{3}{*}{136} & 342609103172701 & 03N.35E.32.41131 & I & $03 / 16 / 77$ & 4,381 & 347.29 & 4,034 \\
\hline & & & & $02 / 23 / 82$ & 4,381 & 351.00 & 4,030 \\
\hline & & & & $01 / 13 / 87$ & 4,381 & 352.56 & 4,028 \\
\hline \multirow[t]{7}{*}{137} & 342615103220701 & 03N.34E.34.31122 & I & $03 / 03 / 62$ & 4,424 & 308.85 & 4,115 \\
\hline & & & & $01 / 30 / 63$ & 4,424 & 311.55 & 4,112 \\
\hline & & & & $02 / 01 / 72$ & 4,424 & 364.33 & 4,060 \\
\hline & & & & $01 / 13 / 77$ & 4,424 & 378.20 & 4,046 \\
\hline & & & & $02 / 26 / 82$ & 4,424 & 388.71 & 4,035 \\
\hline & & & & $01 / 13 / 87$ & 4,424 & 388.20 & 4,036 \\
\hline & & & & 03/07/97 & 4,424 & 391.58 & 4,032 \\
\hline 138 & 342626103195301 & 03N.34E.36.32111 & I & $02 / 10 / 82$ & 4,394 & 343.00 & 4,051 \\
\hline 139 & 342626103204101 & 03N.34E.35.41111 & I & $02 / 26 / 82$ & 4,407 & 349.04 & 4,058 \\
\hline \multirow[t]{8}{*}{140} & 342630103145201 & 03N.35E.35.31111 & I & $04 / 21 / 54$ & 4,347 & 295.49 & 4,052 \\
\hline & & & & $01 / 09 / 56$ & 4,347 & 303.31 & 4,044 \\
\hline & & & & $01 / 16 / 57$ & 4,347 & 304.24 & 4,043 \\
\hline & & & & $01 / 22 / 58$ & 4,347 & 302.98 & 4,044 \\
\hline & & & & $01 / 19 / 59$ & 4,347 & 301.86 & 4,045 \\
\hline & & & & $01 / 19 / 61$ & 4,347 & 304.06 & 4,043 \\
\hline & & & & $01 / 17 / 62$ & 4,347 & 304.15 & 4,043 \\
\hline & & & & $01 / 22 / 63$ & 4,347 & 307.21 & 4,040 \\
\hline
\end{tabular}


Table I-2. Altitudes of water levels in selected wells at Cannon Air Force Base and the surrounding area.-Continued [Monitoring well, Cannon Air Force Base monitoring well; Primary use of water: I, irrigation; O, observation; S, stock watering; U, unused; Z, other; W, withdrawal; ---, not recorded].

\begin{tabular}{|c|c|c|c|c|c|c|c|}
\hline $\begin{array}{c}\text { Map } \\
\text { identifier } \\
\text { (fig. I-1) }\end{array}$ & $\begin{array}{c}\text { U.S. Geological Survey } \\
\text { identifier }\end{array}$ & Township and range & $\begin{array}{c}\text { Primary } \\
\text { use of } \\
\text { water }\end{array}$ & $\begin{array}{c}\text { Water- } \\
\text { level } \\
\text { date }\end{array}$ & $\begin{array}{c}\text { Altitude } \\
\text { of land } \\
\text { surface } \\
\text { (feet above } \\
\text { NAVD 88) }\end{array}$ & $\begin{array}{c}\text { Water } \\
\text { level } \\
\text { (feet } \\
\text { below } \\
\text { land } \\
\text { surface) }\end{array}$ & $\begin{array}{c}\text { Altitude } \\
\text { of water } \\
\text { level } \\
\text { (feet above } \\
\text { NAVD 88) }\end{array}$ \\
\hline & & & & $01 / 14 / 64$ & 4,347 & 310.69 & 4,036 \\
\hline & & & & $01 / 12 / 66$ & 4,347 & 314.65 & 4,032 \\
\hline & & & & $01 / 11 / 68$ & 4,347 & 322.00 & 4,025 \\
\hline & & & & $02 / 04 / 77$ & 4,347 & 327.84 & 4,019 \\
\hline \multirow[t]{2}{*}{141} & 342630103231901 & 03N.34E.33.13331 & 1 & $02 / 10 / 82$ & 4,422 & 385.60 & 4,036 \\
\hline & & & & $01 / 08 / 87$ & 4,422 & 379.19 & 4,043 \\
\hline \multirow[t]{24}{*}{142} & 342633103155301 & 03N.35E.34.11133 & I & $01 / 06 / 71$ & 4,369 & 328.16 & 4,041 \\
\hline & & & & $01 / 27 / 72$ & 4,369 & 332.35 & 4,037 \\
\hline & & & & $01 / 04 / 73$ & 4,369 & 336.07 & 4,033 \\
\hline & & & & $01 / 03 / 74$ & 4,369 & 333.50 & 4,036 \\
\hline & & & & $01 / 04 / 75$ & 4,369 & 336.32 & 4,033 \\
\hline & & & & $01 / 07 / 76$ & 4,369 & 332.60 & 4,036 \\
\hline & & & & $01 / 05 / 77$ & 4,369 & 333.84 & 4,035 \\
\hline & & & & $01 / 07 / 78$ & 4,369 & 333.65 & 4,035 \\
\hline & & & & $01 / 06 / 79$ & 4,369 & 334.52 & 4,034 \\
\hline & & & & $01 / 08 / 80$ & 4,369 & 338.80 & 4,030 \\
\hline & & & & $01 / 12 / 81$ & 4,369 & 343.77 & 4,025 \\
\hline & & & & $02 / 23 / 82$ & 4,369 & 342.44 & 4,027 \\
\hline & & & & $01 / 10 / 83$ & 4,369 & 342.98 & 4,026 \\
\hline & & & & $01 / 18 / 84$ & 4,369 & 340.54 & 4,028 \\
\hline & & & & $01 / 11 / 85$ & 4,369 & 338.58 & 4,030 \\
\hline & & & & $01 / 13 / 87$ & 4,369 & 340.02 & 4,029 \\
\hline & & & & $01 / 12 / 88$ & 4,369 & 340.19 & 4,029 \\
\hline & & & & $01 / 04 / 90$ & 4,369 & 346.77 & 4,022 \\
\hline & & & & $01 / 04 / 91$ & 4,369 & 343.99 & 4,025 \\
\hline & & & & $01 / 02 / 92$ & 4,369 & 343.46 & 4,026 \\
\hline & & & & $01 / 07 / 94$ & 4,369 & 351.84 & 4,017 \\
\hline & & & & $01 / 22 / 97$ & 4,369 & 345.31 & 4,024 \\
\hline & & & & 03/12/02 & 4,369 & 346.36 & 4,023 \\
\hline & & & & $03 / 11 / 04$ & 4,369 & 348.68 & 4,020 \\
\hline \multirow[t]{3}{*}{143} & 342638103162401 & 03N.35E.33.21111 & I & $03 / 03 / 62$ & 4,378 & 313.75 & 4,064 \\
\hline & & & & $01 / 19 / 67$ & 4,378 & 323.10 & 4,055 \\
\hline & & & & $02 / 04 / 77$ & 4,378 & 335.40 & 4,043 \\
\hline \multirow[t]{5}{*}{144} & 342653103195201 & 03N.34E.25.33222 & I & $01 / 20 / 69$ & 4,406 & 322.03 & 4,084 \\
\hline & & & & $01 / 27 / 72$ & 4,406 & 325.88 & 4,080 \\
\hline & & & & $01 / 13 / 77$ & 4,406 & 330.27 & 4,076 \\
\hline & & & & $02 / 26 / 82$ & 4,406 & 334.62 & 4,071 \\
\hline & & & & $01 / 13 / 87$ & 4,406 & 336.15 & 4,070 \\
\hline \multirow[t]{2}{*}{145} & 342655103151401 & 03N.35E.27.43414 & I & $02 / 19 / 82$ & 4,364 & 331.82 & 4,032 \\
\hline & & & & $01 / 13 / 87$ & 4,364 & 332.40 & 4,032 \\
\hline
\end{tabular}


